\author{
UNIVERSIDADE DE SÃO PAULO \\ ESCOLA DE ENGENHARIA DE SÃO CARLOS \\ DEPARTAMENTO DE HIDRÁULICA E SANEAMENTO \\ CENTRO DE RECURSOS HÍDRICOS E ECOLOGIA APLICADA
}

ANDRÉ AUKAR BRITSCHGY DE CAMARGO

AVALIAÇÃO E QUANTIFICAÇÃO DA CONTRIBUIÇÃO DE UMA VOÇOROCA PARA O ASSOREAMENTO DO RIBEIRÃO DAS CRUZES, TRIBUTÁRIO DA REPRESA DE TRÊS IRMÃOS, SP

São Carlos 



\section{AVALIAÇÃO E QUANTIFICAÇÃO DA CONTRIBUIÇÃO DE UMA VOÇOROCA PARA O ASSOREAMENTO DO RIBEIRÃO DAS CRUZES, TRIBUTÁRIO DA REPRESA DE TRÊS IRMÃOS, SP}

Dissertação apresentada à Escola de Engenharia de São Carlos, da Universidade de São Paulo, como parte dos requisitos para obtenção do título de mestre em Ciências da Engenharia Ambiental.

Área de Concentração: Engenharias I

Orientador: Prof. Dr. Frederico Fábio Mauad

São Carlos 
AUTORIZO A REPRODUÇÃO E DIVULGAÇÃO TOTAL OU PARCIAL DESTE TRABALHO, POR QUALQUER MEIO CONVENCIONAL OU ELETRÔNICO, PARA FINS DE ESTUDO E PESQUISA, DESDE QUE CITADA A FONTE.

Ficha catalográfica preparada pela Seção de Tratamento da Informação do Serviço de Biblioteca - EESC/USP Camargo, André Aukar Britschgy de
C172a Avaliação e quantificação da contribuição de uma
voçoroca para o assoreamento do Ribeirão das cruzes, tributário da Represa de Três Irmãos, SP. / André Aukar Britschgy de Camargo ; orientador Frederico Fábio Mauad. São Carlos, 2012.

Dissertação (Mestrado - Programa de Pós-Graduação em Ciências da Engenharia Ambiental e Área de Concentração em Engenharias I)-- Escola de Engenharia de São Carlos da Universidade de São Paulo, 2012.

1. Sedimentometria. 2. Erosão linear. 3. Assoreamento. I. Título. 


\section{FOLHA DE JULGAMENTO}

\section{Candidato: Engenheiro ANDRÉ AUKAR BRITSCHGY DE CAMARGO.}

Título da dissertação: "Avaliação e quantificação da contribuição de uma voçoroca para o assoreamento do Ribeirão das Cruzes, tributário da represa de Três Irmãos, SP".

Data da defesa: 29/06/2012

\section{Comissão Julgadora:}

Prof. Dr. Frederico Fabio Mauad (Orientador)

(Escola de Engenharia de São Carlos/EESC)

Prof. Dr. Oswaldo Augusto Filho

(Escola de Engenharia de São Carlos/EESC)
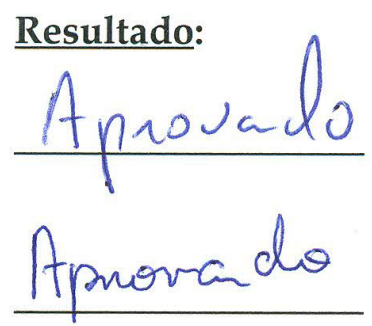

Prof. Dr. Cristiano Poleto

(Universidade Tecnológica Federal do Paraná/UTFPR)

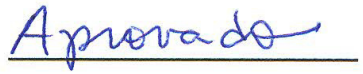

Coordenador do Programa de Pós-Graduação em Ciências da Engenharia Ambiental: Prof. Dr. Frederico Fabio Mauad

Presidente da Comissão de Pós-Graduação:

Prof. Titular Denis Vinicius Coury 



\section{AGRADECIMENTOS}

Ao professor Dr. Frederico Fábio Mauad, pela orientação, compreensão, incentivo, crédito, confiança, amizade e conselho para o desenvolvimento deste trabalho.

Aos amigos e companheiros do Núcleo de Hidrometria Gustavo, Renato, Diego, Julio, Marcus, Edwardo, Juliana, Roberta, Taiana, e ao Paulo pela convivência e pela amizade destes últimos anos.

Aos técnicos de laboratório Waldomiro e Paulinho pelo seus conhecimentos que tornaram a coleta de dados possível.

À todos os funcionários do CRHEA e da USP São Carlos que tornaram esta pesquisa possível.

Aos amigos e companheiros de república Davi, Caio, Dante, Patrik, Thiago, Rodrigo, Francys, Murilo, Roger, Victor, Ricardo, Norvin, Evillin, Cheech e Chong's e Maria pela compreensão, amizade, cantorias e criações musicais nestes últimos anos.

Aos meus queridos amigos e sócios Engenheiros Thays Ferreira, Thiago Decina, Dante José, Davi Loio e Caio Pires que acreditaram na construção de um sonho.

Aos meus queridos amigos de Ribeirão Preto, da turma de 2005 da Engenharia Ambiental, Rosemary e Márcia pelo apoio.

À CAPES pela concessão da bolsa de estudo.

À todo amor da minha família em especial do meu irmão Lucas, meu pai Rafael e minha mãe Rosângela, que sempre me incentivaram e me apoiaram as minhas decisões. Meus exemplos de vida.

À DEUS por sua infinita sabedoria e magnitude. 



\section{EPÍGRAFE}

"Madre tierra, Pachamama, tierra bendita de donde brota el agua, donde el lucero refleja su alma, donde la luna se quiebra extasiada.

Ríos, vertientes brotan de tu corazón, amamantando y sembrando vida en diáfanos campos.

Donde la espiga danza con el viento, en honor a tí, Pachamama querida.

Donde los verdes bosques entonan melodías, respondiéndo en coros los trinares de alegrías.

Donde las flores renacen cada primavera, vistiéndote de colores y perfumándote con jazmines y azahares porque, eres la madre nuestra,la Pachamama y estamos de fiesta.

Gracias, Madre Tierra gracias, Pachamama por el néctar de la vida." 



\section{RESUMO}

CAMARGO, A. A. B. Avaliação e quantificação da contribuição de uma voçoroca para o assoreamento do Ribeirão das Cruzes, tributário da represa de Três Irmãos, SP. 2012. Dissertação (Mestrado) - Escola de Engenharia de São Carlos, Universidade de São Paulo, São Carlos, 2012.

Devido a dificuldade em se modelar a contribuição de aporte de sedimentos provenientes de erosões lineares em uma bacia hidrográfica, muitas vezes estes são desconsiderados nos estudos hidrossedimentológicos, contudo, podem corresponder a parcela significativa do assoreamento. O presente projeto analisou como a contribuição de uma voçoroca no município de Santo Antônio do Aracanguá (SP), para o assoreamento do Ribeirão das Cruzes, tributário do reservatório da UHE Três Irmãos (Rio Tietê). O estudo foi conduzido por meio de pesquisa teórica (levantamento bibliográfico), coletas de dados na área de estudo e por meio de simulação computacional. Com auxílio de ferramentas de geoprocessamento foram quantificados o volume assoreado no tributário determinado por levantamento batimétrico $\left(12,31 \mathrm{hm}^{3}\right)$ e o volume de solo erodido na voçoroca por meio de levantamento topográfico $\left(0,22 \mathrm{hm}^{3}\right)$. Comparando estes resultados obtivemos a contribuição de $1,80 \%$ da erosão linear para o assoreamento do tributário nos 21,12 anos anteriores a pesquisa. No entanto, devido a estimativa do surgimento e desenvolvimento da voçoroca estar associado aos últimos 7,11 anos, a contribuição no assoreamento para este período foi de $5,17 \%$. O estudo ainda apontou o depósito destes sedimentos nos primeiros $2 \mathrm{~km}$ à jusante da interface erosão-represa. Erosões lineares podem contribuir significativamente no processo de assoreamento como demonstrado no estudo de caso, sendo necessário se considerar este tipo de contribuição nos estudos de aporte de sedimento em corpos d'água.

Palavras-chave: sedimentometria, erosão linear, assoreamento 



\begin{abstract}
CAMARGO, A. A. B. Assessment and quantification of a gully erosion contribution to the Ribeirão das Cruzes siltation, a tributary of the Três Irmãos dam, SP. 2012. Dissertation (Master) - Escola de Engenharia de São Carlos, Universidade de São Paulo, São Carlos, 2012.

Due the difficulty of modeling the contribution of sediment delivery from linear erosions in a watershed, these are often overlooked in hydrosedimentological studies, however, may represent a significant portion of siltation. This project analyzes the contribution of a gully erosion in Santo Antonio do Aracanguá (SP) for the sedimentation of Ribeirão das Cruzes, a tributary of the UHE Three Brothers reservoir (Tietê River). The study was conducted from theoretical research (bibliographic research), data collection in the study area and through computer simulation. With the aid of GIS tools were quantified the silted volume in the tributary, determined by bathymetric survey $\left(12.31 \mathrm{hm}^{3}\right)$ and the volume of eroded soil in the gully erosion by topography surveying $\left(0.22 \mathrm{hm}^{3}\right)$. Comparing these results, we have obtained the contribution of $1.80 \%$ from linear erosion to the sedimentation in the tributary during the 21.12 years preceding the survey. However, due to estimative of the beginning and development of the gully erosion being associated with the last 7.11 years, the contribution to sedimentation in this period was $5.17 \%$. The study also accused the deposit of sediment in the first $2 \mathrm{~km}$ downstream interface "erosion-dam". Linear erosions can contribute significantly in the process of sedimentation as shown in the study case, being necessary to consider this type of contribution in studies of sediment input into water bodies.
\end{abstract}

Palavras-chave: sediment research, gully erosion, siltation 



\section{LISTA DE FIGURAS}

Figura 1. Gráfico de eficiência de retenção de sedimento de Brune (1953) 57

Figura 2. Localização da Bacia Hidrográfica do Ribeirão das Cruzes no Estado de São Paulo.

Figura 3. Uso e ocupação do solo na bacia hidrográfica do Ribeirãos das Cruzes.

Figura 4. Imagem do local (20/11/2001) com perímetro da bacia hidrográfica do Riberão das Cruzes.

Figura 5. Ocupação das margens do Ribeirão das Cruzes por pastagens. 63

Figura 6. Ocupação do entorno da voçoroca por pastagem (janeiro de 2011). 64

Figura 7. Ocupação do entorno da voçoroca por cana-de-açúcar (setembro de 2011). 64

Figura 8. Caracterização da bacia hidrográfica do Ribeirão das Cruzes. A: Unidades litológicas. B: Teor de salinidade. C: Tipos de solo. Datum: Córrego Alegre. 65

Figura 9. Susceptibilidade à erosão da bacia hidrográfica do Ribeirão das Cruzes. Datum: Córrego Alegre.

Figura 10. Área de estudo: trecho da voçoroca.

Figura 11. Corte transversal da voçoroca com as vertentes superiores direita e esquerda (VSD/VSE), vertentes inferiores direita e esquerda (VID/VIE), pontos intermediários $(\mathrm{pI})$ e pontos de controle $(\mathrm{pC})$.

Figura 12. Corte longitudinal da voçoroca com alocação adequada dos pontos notáveis horizontais. .70

Figura 13. Imagens históricas de sensoriamento remoto Landsat TM5 para a região da voçoroca.

Figura 14. Coleta de pontos: Estação Total no interior da voçoroca.......................................81

Figura 15. Exemplo de georreferenciamento de um plano XY em UTM WGS84 .................83

Figura 16. Distribuição dos pontos intermediários no interior da voçoroca. ............................. 84

Figura 17. Exemplo da distribuição dos pontos coletados em uma região da voçoroca e o resultado obtido com a interpolação.

Figura 18. Exemplo da distribuição dos pontos coletados e acrescentados em uma região da voçoroca e o resultado obtido com a interpolação.

Figura 19. Distribuição dos pontos de georreferenciamento das cartas do IGGSP...................8 88

Figura 20. Exemplo de uma interpolação sem e com a consideração do fundo de vale. 88 
Figura 21. Distribuição dos elementos gráficos na bacia hidrográfica do Ribeirão das Cruzes.

Datum horizontal: Córrego Alegre. Datum vertical: Tôrres (RS). 89

Figura 22. Traçado da bacia hidrográfica do Ribeirãos das Cruzes e traçado da bacia hidrográfica da voçoroca. Datum horizontal: Córrego Alegre............................... 90

Figura 23. Exemplo dos traçados realizados pelo barco na coleta dos dados de batimetria.... 91

Figura 24. Limite da interpolação dos dados de batimetria. 93

Figura 25. Exemplo da interpolação dos dados do IGGSP (1967) e das batimetrias de 1967, 2008 e 2011, respectivamente, para um trecho do Ribeirão das Cruzes. 94

Figura 26. Exemplo do assoreamento e erosão no leito do Ribeirão das Cruzes para os períodos de 1967 à 2008, 2008 à 2011, e 1967 à 2011, respectivamente. 96

Figura 27. Curva COTA X VOLUME de 1967, 2008 e 2011 para o Ribeirão das Cruzes... 100

Figura 28. Regiões ou trechos de análise individual de taxas de assoreamento. 101

Figura 29. Taxa de assoreamento individual de cada região estipulada no Ribeirão das Cruzes. 


\section{LISTA DE TABELAS}

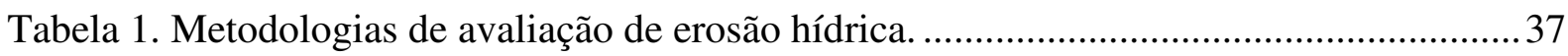

Tabela 2. Métodos de avaliação do processo de assoreamento em reservatórios. ...................58

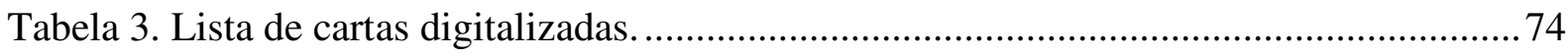

Tabela 4. Coordenadas geográficas WGS 84 e UTM Fuso 22 das estação do levantamento topográfico. 82

Tabela 5. Resultados obtidos para os valores de área 2D, área 3D e volume para os MDT's da área de estudo com e sem a presença da voçoroca. 86

Tabela 6. Resultados obtidos para os valores de área 2D e área 3D para as bacias hidrográficas do Ribeirão das Cruzes e da voçoroca.

Tabela 7. Valores de leitura de régua e profundidade do transdutor nos dias de coleta de campo.

Tabela 8. Resultados obtidos para os valores de área 2D, área 3D e volume para os MDT's da Carta IGGSP (1967) e das batimetrias de 1967, 2008 e 2011.

Tabela 9. Distribuição do volume de água armazenado por cota segundo os MDT's das

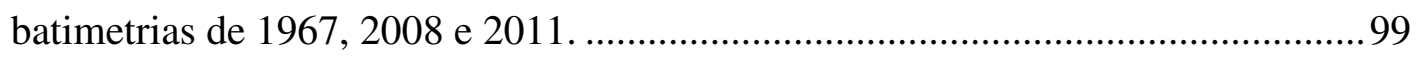

Tabela 10. Taxa de assoreamento por período e região. ...................................................... 102

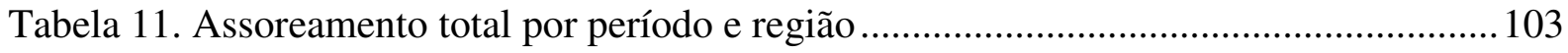




\section{LISTA DE SIGLAS}

ABNT - Associação Brasileira de Normas Técnicas

ANEEL - Agência Nacional de Energia Elétrica

APP - Área de Preservação Permanente

CESP - Companhia Energética de São Paulo

CPRM - Companhia de Pesquisa de Recursos Naturais

CRHEA - Centro de Recursos Hídricos e Ecologia Aplicada

DEM - Digital Elevation Model

DGPS - Differential Global Positioning System

EUPS - Equação Universal da Perda de Solo

FIPAI - Fundação para o Incremento da Pesquisa e do Aperfeiçoamento Industrial

GPS - Global Positioning System

INPE - Instituto Nacional de Pesquisas Espaciais

LIDAR - Light Detection And Ranging

MDT - Modelo Digital do Terreno

NBR - Norma Brasileira

pC - Ponto de Controle

pI - Ponto Intermediário

PNRH - Plano Nacional de Recursos Hídricos

SIG - Sistema de Informação Geográfica

SHS - Departamento de Hidráulica e Saneamento

SRTM - Shuttle Radar Topography Mission

TIF - Tagged Image File

TIN - Triangulated Irregular Network

UGRHI - Unidades de Gerenciamento de Recursos Hídricos

UHE - Usina Hidrelétrica

UTM - Universal Transverse Mercator

VID - Vertente Inferior Direita

VIE - Vertente Inferior Esquerda

VSD - Vertente Superior Direita

VSE - Vertente Superior Esquerda

WGS - World Geodetic System 


\section{SUMÁRIO}

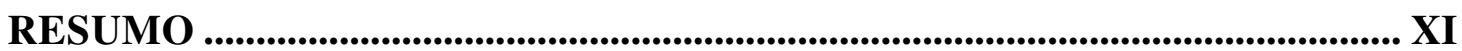

ABSTRACT .....................................................................................................

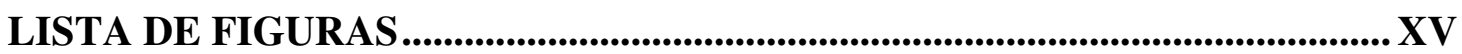

LISTA DE TABELAS ...............................................................................

LISTA DE SIGLAS .......................................................................................... XVIII

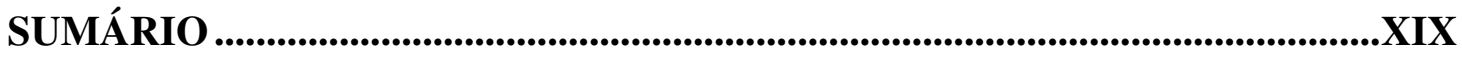

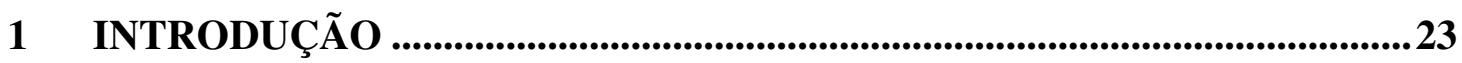

2 OBJETIVOS …….......................................................................................................25

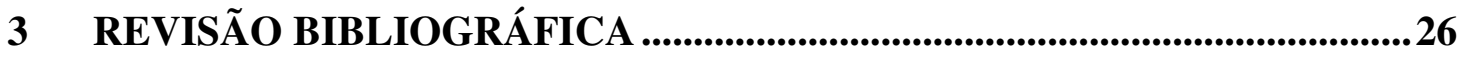

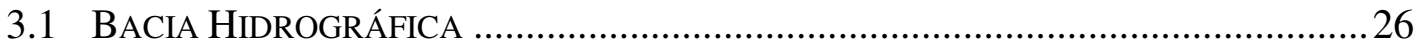

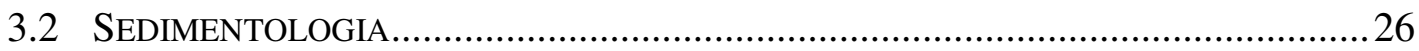

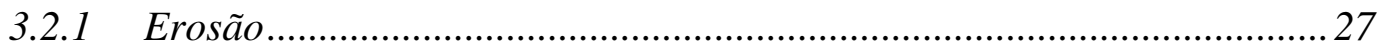

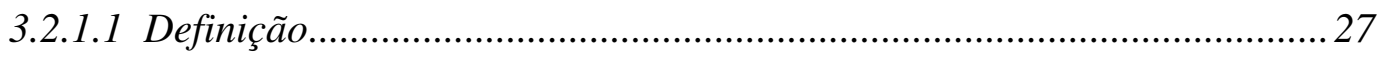

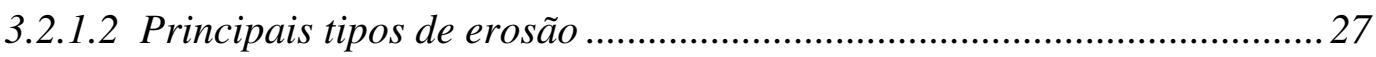

3.2.1.3 Feiçôes erosivas.....................................................................................2

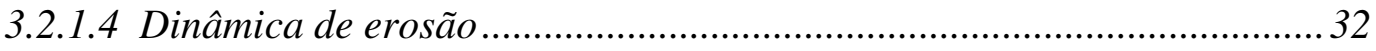

3.2.1.5 Agentes erosivos e condicionantes da erosão linear ...................................33

3.2.2 Métodos de avaliação dos processos erosivos ………………………........ 37

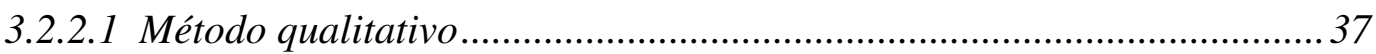

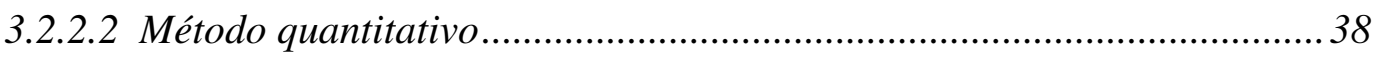

3.2.2.3 Equação Universal da Perda de Solo - EUPS...........................................41

3.2.3 Deposição de sedimentos...................................................................... 42

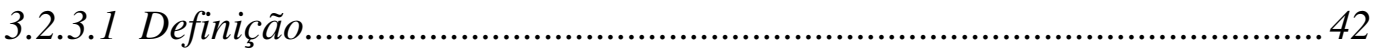

3.2.3.2 Dinâmica e tipos de deposição ............................................................... 45

3.2.4 Métodos de avaliação do processo de deposição ......................................4

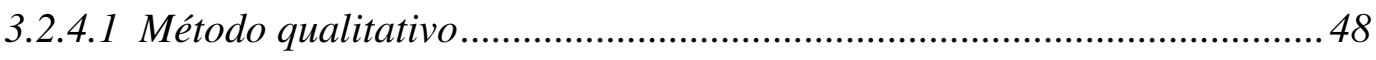

3.2.4.2 Método quantitativo............................................................................... 49

4 MATERIAIS E MÉTODOS …...............................................................60 


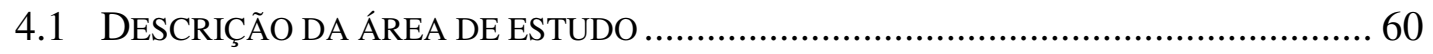

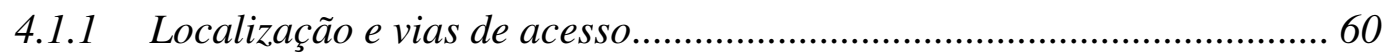

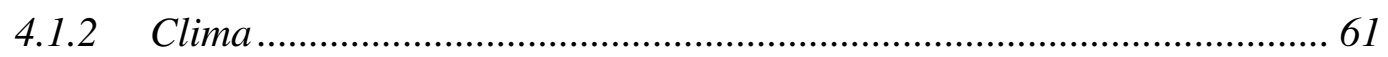

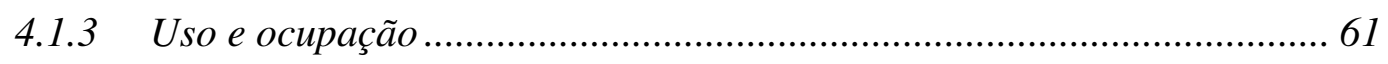

4.1.4 Geologia, pedologia e geomorfologia................................................. 65

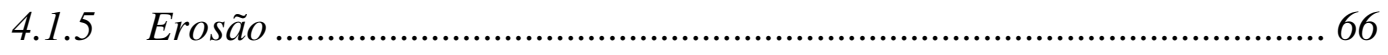

4.2 PROCESSO DE ASSOREAMENTO RELACIONADO A EROSÃO LINEAR ...................... 67

4.2.1 Análise da existência da voçoroca ....................................................... 68

4.2.2 Quantificação do volume do solo erodido na voçoroca .......................... 68

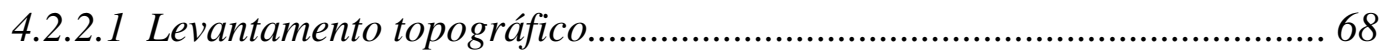

4.2.2.2 Análise de consistência e tratamento de dados ....................................... 70

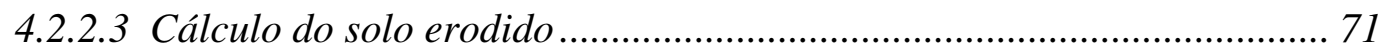

4.2.3 Quantificação do volume do assoreamento no Ribeirão das Cruzes entre os anos de 1967 e 2011 ............................................................................ 73

4.2.3.1 Modelo digital do terreno original, anterior ao enchimento da barragem da UHE Três Irmãos .......................................................................... 73

4.2.3.2 Delimitação do perímetro do alagamento .............................................. 75

4.2.3.3 Delimitação das bacias hidrográficas .................................................. 75

4.2.3.4 Levantamentos batimétricos................................................................. 75

4.2.3.5 Análise de consistência e tratamento de dados...................................... 76

4.2.3.6 Cálculo do volume de assoreamento.................................................... 77

5 RESULTADOS E DISCUSSÃO ................................................................. 79

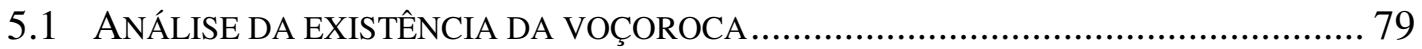

5.2 QUANTIFICAÇÃO DO VOLUME DO SOLO ERODIDO NA VOÇOROCA ...................... 81

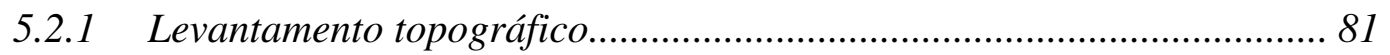

5.2.2 Análise de consistência e tratamento de dados....................................... 82

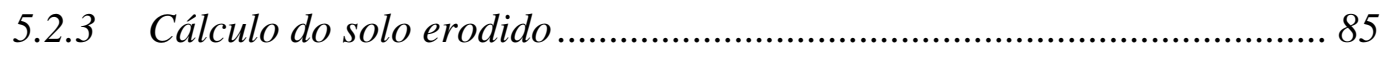

5.3 QUANTIFICAÇÃO DO VOLUME DO ASSOREAMENTO NO RIBEIRÃO DAS CRUZES

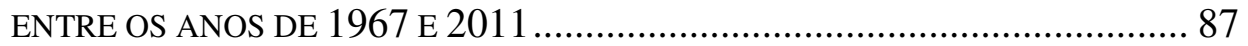

5.3.1 Modelo digital do terreno original, anterior ao enchimento da barragem da UHE Três Irmãos ........................................................................... 87

5.3.2 Delimitação do perímetro do alagamento ............................................. 89 
5.3.3 Delimitação das bacias hidrográficas ...................................................90

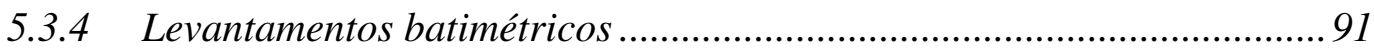

5.3.5 Análise de consistência e tratamento de dados ...................................... 92

5.3.6 Cálculo do volume de assoreamento .................................................... 92

5.4 CONTRIBUIÇÃO DA VOÇOROCA PARA O ASSOREAMENTO DO RIBEIRÃO DAS

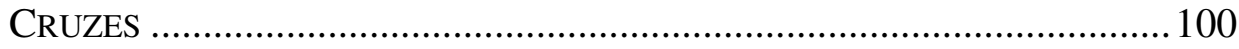

6 CONCLUSÃ

7 REFERÊNCIAS BIBLIOGRÁFICAS ...............................................................106

APÊNDICE A - ..................................................................................................116

APÊEDICE B - ................................................................................................... 117

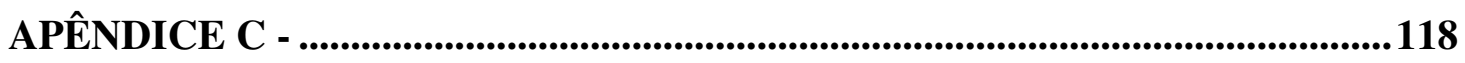

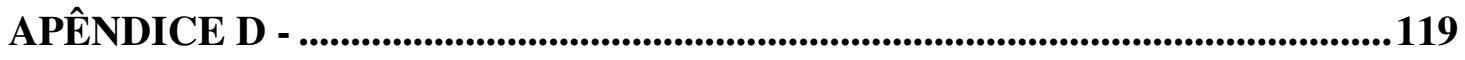

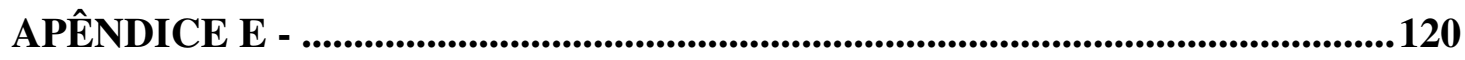

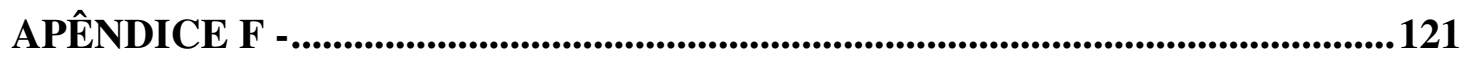

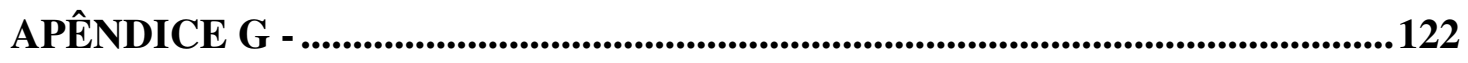

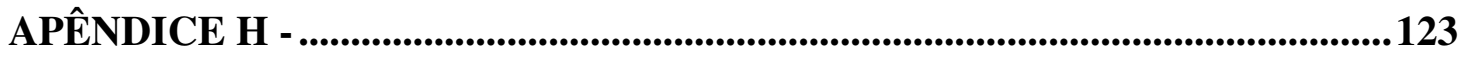

APENDICE I

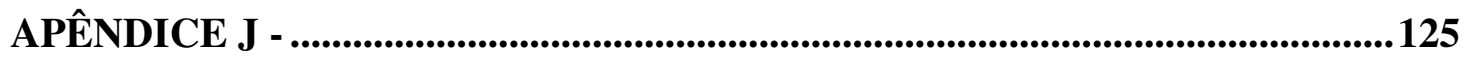

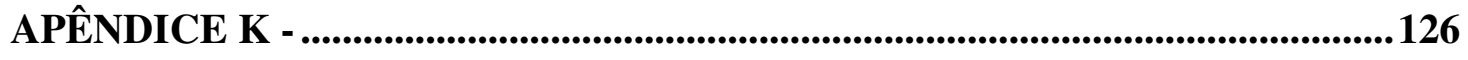

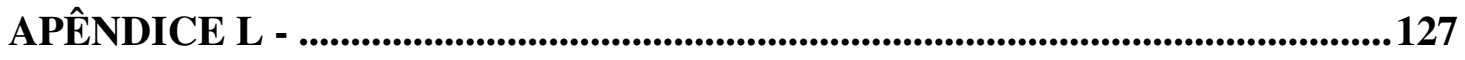

APÊNDICE $M$ 



\section{INTRODUÇÃO}

O estudo do processo de assoreamento em reservatórios vem ganhado notória importância nas áreas acadêmica, de administração pública e de interesses particulares devido às consequências desastrosas à economia, sociedade e ao meio ambiente, observadas e registradas no decorrer de anos de negligência ao tema. A obstrução de hidrovias, tomadas de água e obras de arte, a interferência na produção de energia hidrelétrica, o encarecimento do tratamento da água para consumo, o aumento nos índices de inundações, o soterramento de várzeas, o comprometimento de ecossistemas submersos, a diminuição na capacidade de dissolver oxigênio, dentre outros, são alguns exemplos dos diversos problemas enfrentados pela sociedade em suas diversas esferas, acarretados pelos processos de deposição acelerados nestes ambientes lacustres.

A tendência do material particulado solto e transportado, dentre outras formas pela ação do escoamento superficial da água no solo, é de se depositar em regiões de baixa turbulência e energia potencial, muitas delas ocupadas pelos corpos hídricos.

Sua previsão, através de estudos qualitativos e quantitativos, é o foco dos trabalhos acadêmicos em sedimentologia, que buscam mapear áreas críticas e contabilizar variações volumétricas de erosões e depósitos, a fim de se evitar o agravamento do assoreamento e direcionar as ações públicas e particulares para sua prevenção, contenção e remediação.

As ações de prevenção buscam estudar as origens dos efeitos desencadeadores do processo de assoreamento de represas. Neste contexto, a erosão constitui o início de todos os problemas derivados do sedimento no meio ambiente, sendo, portanto, o foco das ações conjuntas dos estudos de assoreamento.

Dentre os modelos empíricos mais empregados que contabilizam a erosão em uma bacia hidrográfica está a Equação Universal da Perda de Solo (EUPS) e suas derivações proposta inicialmente por Wischmeier \& Smith (1978). A aplicação deste modelo permite estimar e espacializar as taxas médias anuais da perda de solo que estão associadas à erosão laminar e pequenos sulcos, quando aplicada a áreas homogêneas com declividade uniforme. Estas equações são comumente empregadas na determinação do aporte de sedimentos e consequente assoreamento que um determinado corpo hídrico irá sofrer. Apesar da modelação da erosão laminar prevalecer nos trabalhos acadêmicos, os valores de sedimentos provenientes de processos erosivos agressivos, como ravinas e voçorocas, não são 
considerados nas previsões realizadas pela EUPS, devido a grande dificuldade em se modelar a dinâmica destas feições erosivas e o volume de material erodido.

Alguns estudos demonstram que as contribuições de erosões lineares profundas, no aporte de sedimentos nos recursos hídricos superficiais, são significativas e relevantes no processo de assoreamento de reservatórios, no entanto, a discussão que se segue no meio acadêmico é a dificuldade em se obter dados reais consistentes para modelação e compreensão destes tipos de erosão no processo de deposição de sedimentos nos corpos d'água. Muitos grupos de trabalho se focam em compreender a dinâmica das ravinas e voçorocas, com auxílio de equipamento e técnicas de sensoriamento remoto, para obter relações matemáticas entre suas características físicas, como profundidade e largura da erosão e, assim, prever o volume do solo desprendido e transportado.

No entanto, a dificuldade dos estudos de quantificação volumétrica da perda de solo em ravinas e voçorocas, ainda está no aprimoramento das técnicas e metodologias que as tornem mais rápidas, exatas e acessíveis sendo, ainda, as mensurações diretas in situ as mais confiáveis e consagradas no campo da sedimentologia. Assim, estudos que preveem a contribuição da erosão em uma bacia hidrográfica para o assoreamento de um corpo hídrico no fundo de vale, ou ao inverso, que quantificam a erosão em uma bacia hidrográfica com base no volume de solo depositado no leito, por exemplo, de reservatórios, atribuem os valores obtidos a uma erosão uniforme, em toda área estudada, desconsiderando a ação das erosões lineares profundas.

Com este enfoque, o presente trabalho tem como objetivo analisar e quantificar a contribuição de uma voçoroca no processo de assoreamento de um corpo hídrico represado, utilizando dados reais mensurados em campo, tomando como estudo de caso, um tributário da represa da Hidrelétrica Três Irmãos, localizados a noroeste do Estado de São Paulo. 


\section{OBJETIVOS}

Avaliar e quantificar a contribuição de uma voçoroca no município de Santo Antônio do Aracanguá/SP, para o assoreamento do Ribeirão das Cruzes, tributário da represa de Três Irmãos.

Objetivos específicos do estudo foram:

- Representar graficamente o perfil longitudinal da erosão linear através da modelação digital do terreno.

-Representar graficamente o perfil longitudinal do assoreamento do Ribeirão das Cruzes para três períodos de estudo, 1967, 2008 e 2011, através da modelação digital do terreno.

- Determinar a evolução do processo de deposição de sedimentos no interior do Ribeirão das Cruzes de 1967 à 2011.

-Relacionar o volume de assoreamento com o volume de material erodido.

-Analisar a relevância da contribuição da voçoroca para o assoreamento do Ribeirão das Cruzes. 


\section{REVISÃO BIBLIOGRÁFICA}

\subsection{Bacia Hidrográfica}

A Bacia Hidrográfica é uma área de captação natural de água da precipitação que faz convergir os escoamentos para um único ponto de saída, seu exutório. Esta se compõe basicamente de um conjunto de superfícies vertentes e uma rede de drenagem formada por cursos de água que confluem até resultar um leito único no exutório (TUCCI, 2002). Ainda definida pela Política Nacional dos Recursos Hídricos (PNRH) n ${ }^{\circ}$ 9.433, de 8 de Janeiro de 1997, a Bacia Hidrográfica representa a unidade territorial para implementação da PNRH e atuação do Sistema Nacional de Gerenciamento de Recursos Hídricos.

A visão de Bacia Hidrográfica feita por Tucci (2002), considerada um sistema físico onde a entrada é o volume de água precipitado e a saída é o volume de água escoado pelo exutório, considerando-se como perdas intermediárias os volumes evaporados, transpirados e os infiltrados profundamente, é complementada por Costa (2009) quando este menciona que o funcionamento desta exige o conhecimento de todos os seus componentes aquáticos e terrestres. Todas as áreas urbanas industriais, agrícolas ou de preservação fazem parte de alguma bacia hidrográfica, podendo-se dizer que, no seu exutório, estarão representados todos os processos que fazem parte do seu sistema (PORTO, 2008). Deste modo, quando uma bacia sofre uma modificação considerável, principalmente no solo, diversas alterações podem ocorrer afetando diretamente os cursos d'água.

\subsection{Sedimentologia}

Um dos problemas de relevante interesse acadêmico, decorrentes do uso e ocupação inadequada do solo nas bacias hidrográficas e dos intemperismos presentes no meio ambiente, está diretamente relacionado aos sedimentos e seus impactos associados desde sua produção à deposição final. Neste contexto, a sedimentologia, disciplina que estuda os sedimentos, abrange uma área de conhecimento com grande importância mundial, que compreende os estudos de processos complexos que envolvem erosão, deslocamento das partículas até os rios, transporte do sedimento nos cursos d'água, deposição do sedimento na calha dos rios, lagos e reservatórios e sua compactação (CARVALHO, 2008). Alguns dos estudos que utilizam a sedimentologia em seus planejamentos são, por exemplo, projetos e operações de obras fluviais tais como pontes, 
hidrovias, portos, barragens, hidroelétricas, bem como para o planejamento da conservação dos recursos hídricos e das terras agricultáveis.

\subsubsection{Erosão}

\subsubsection{Definição}

Erosão, palavra com origem etimológica proveniente do Latim "erodere" (ZACHAR, 1982) ou "erosio" (LAL, 1990), que significa corroer ou desgastar, é o nome dado ao processo, ou conjunto de processos, que promovem o desgaste do relevo, através da desagregação e transporte de partículas de solo, rochas ou fragmentos, por ação da água, vento ou gelo (DAEE/IPT, 1990; CARVALHO et. al., 2006; CARVALHO, 2008). Estes fenômenos de desprendimento e arraste das partículas, que ocorrem de forma natural, aos quais chamamos de erosão natural ou geológica, são responsáveis pelo desgaste dos relevos ao longo de centenas de anos pela ação dos agentes erosivos, elementos do meio físico que causam ou afetam diretamente a erosão (DAEE/IPT, 1990; CARVALHO, 2008). Quando acelerados por ação do homem, erosão acelerada, estes fenômenos provocam o desequilíbrio entre a formação e transporte do solo, desencadeando problemas de cunho econômico (RYZHOV, 2009; FRANKL et al., 2011), social (RYZHOV, 2009) e ambiental (KOLDING; ZWIETEN, 2012).

\subsubsection{Principais tipos de erosão}

Os processos erosivos ocorrem em todo o globo terrestre sob diferentes condições impostas pelos diversos ambientes, podendo surgir de várias maneiras (ARAUJO, 2011), dificultando sua compreensão e estudo (CARVALHO, 2008). Para melhor compreender este fenômeno, a erosão pode ser classificada em três grandes tipos: erosão eólica, erosão gravitacional, e erosão hídrica (LAL, 1990; CARVALHO, 2008).

\subsection{Eólica}

Erosão eólica, ou erosão provocada pelo vento, ocorre quando as condições de baixa umidade do terreno diminuem a coesão entre suas partículas, facilitando o desprendimento e transporte pela ação da movimentação de grandes quantidades de ar (CARVALHO, 2008; HOFFMANN et al., 2011; THORARINSDOTTIR; ARNALDS, 2012). A dinâmica do transporte de sedimentos pela ação dos ventos se assemelha ao 
transporte observado em rios. Partículas maiores de solo sofrem a ação turbulenta provocada pela movimentação do vento, se deslocam através da saltação, enquanto partículas menores permanecem em suspensão na massa de ar (THORARINSDOTTIR; ARNALDS, 2012). Uma vez em movimento, as partículas se chocam contra o solo ou a rocha de forma abrasiva, agravando a situação da erosão (ARAUJO, 2011).

$\mathrm{Na}$ região agricultável da estepe Xilingol na China, Hoffmann et al. (2011) estimaram a perda de $30 \mathrm{~mm} / \mathrm{mês}$ de superfície do solo, apenas com a ação de transporte de sedimento provocado pelos ventos em superfícies de solo expostas.

\subsection{Gravitacional}

A erosão gravitacional, ou por remoção em massa, corresponde ao movimento de grande quantidade de materiais das formações superficiais e de rochas, sob a influência da gravidade (CARVALHO, 2008). Este tipo de erosão, geralmente associado à saturação líquida do solo que diminui a coesão das partículas e o torna plástico ou líquido, dependendo do teor de água, pode ser classificado quanto ao fluxo lento ou rápido de material (CARVALHO, 2008).

O fluxo lento pode ocorrer por rastejo e solifluxição. O rastejo, rastejamento ou cripe é o movimento coletivo lento e contínuo das camadas superficiais de solo ou de rocha decomposta sobre as camadas mais profundas. A solifluxão é o movimento lento de uma massa de solo ou rocha decomposta que esteja saturada de água devido a chuvas persistentes (CARVALHO, 2008).

O fenômeno erosivo gravitacional de fluxo rápido é de relevante interesse no estudo de estabilidade de taludes, podendo ocorrer pelo desprendimento de terras ou deslizamento, quando uma porção do solo se desprende do resto do maciço, por escorregamento superficial ou ruptura de talude, quando o deslocamento rápido de uma massa de solo escorrega pela superfície e passa pelo pé do talude, e escorregamento profundo, semelhante ao anterior, porém se caracterizando pela curva de deslizamento passar por um ponto afastado do pé do talude (CARVALHO, 2008). Ji et al. (2012), por exemplo, estudaram a influência mecânica da distribuição das raízes com variação da declividade do terreno na coesão do solo, para abrandamento da erosão e estabilidade de taludes. 


\subsection{Hídrica}

A água, em estado líquido ou sólido, é o principal agente responsável pelo surgimento e desencadeamento dos processos erosivos superficiais, sub-superficiais e subterrâneos observados no globo terrestre (IDE, 2009; RYZHOV, 2009). A ação deflagradora e a capacidade de deslocar os sedimentos exercidas pela água e pelo gelo promove a desagregação das partículas do solo, que sobre a atuação das massas de água, se deslocam da sua posição original para uma região onde diminua ou não esteja presente as forças de arrasto.

$\mathrm{Na}$ erosão glacial, por exemplo, o gelo provoca a erosão do solo e rochas semelhante ao fenômeno provocado pela água. Assim como a água, o gelo exerce grande força contra obstáculos presentes no terreno, fracionando-o em partes menores de rocha que auxiliam na abrasão da superfície por onde se deslocam, promovendo sua corrosão. As feições mais comuns da erosão e transporte pela ação do gelo são ranhuras e sulcos traçados na superfície de solos e rochas (BLOOM, 1970). O fenômeno de congelamento e desgelo da água no solo, em regiões de clima temperado, também interferem na coesão entre as partículas do solo e fragmentos de rocha, aumentando a suscetibilidade ao arrasto e transporte destes materiais pela ação do vento, água, gelo e/ou gravidade. A neve, igualmente, desencadeia processos erosivos, principalmente no período de desgelo, mas também pela ação das avalanches que friccionam e arrastam o solo logo abaixo da camada de neve em movimento (RYZHOV, 2009).

Por outro lado, em regiões tropicais e sub-tropicais, como no caso do Brasil onde as condições de pluviosidade são elevadas, o principal agente desencadeador de processos erosivos são as águas provenientes das chuvas. Todo o percurso da água, da entra ao exutório da bacia hidrográfica, está sujeito aos processos erosivos desencadeados pela ação de sua movimentação.

\subsubsection{Feições erosivas}

\subsection{Laminar}

A erosão laminar é o processo erosivo decorrente do escoamento difuso das águas das chuvas pela encosta, quando o solo superficial já está saturado (CARVALHO, 2008), resultando na remoção progressiva e uniforme dos horizontes superficiais do solo, em 
toda sua extensão, geralmente ocorrendo em locais com pouca ou nenhuma vegetação e/ou obstáculos (DAEE/IPT, 1990).

Esta feição erosiva não é de fácil percepção e pode ser identificada pelo aparecimento de raízes ou marca nas estruturas e queda da produtividade agrícola (CASALÍ et al. 2006; CARVALHO, 2008; DESCROIX et al. 2008).

\subsection{Linear}

A erosão linear ou em sulcos ou ainda por escoamento difuso intenso se caracteriza pela presença de filetes de água percorrendo longas distâncias, desprendendo e transportando grandes quantidades de material, podendo se aprofundar à medida que o escoamento se concentra em um único percurso (DAEE/IPT, 1990; SIDORCHUK, 1999; CARVALHO, 2008; WIRTZ; SEEGER; RIES, 2012). No início, este tipo de feição erosiva hídrica causa pequenas fissuras na superfície do terreno em forma de sulcos, que ao longo do desencadeamento do processo erosivo se aprofundam formando ravinas e, posteriormente, voçorocas (INFANTI JUNIOR; FORNASARI FILHO, 1998). Dentre estes, as voçorocas são as mais preocupantes e o estágio mais avançado (FERREIRA, 2004).

\section{Sulcos}

Erosão por escoamento difuso ou em sulcos é a consequência da concentração das linhas de fluxo das águas de escoamento superficial (DAEE/IPT, 1990), perpendiculares às curvas de nível (CANIL et al., 1995), que se apresentam como pequenas incisões em forma de sulcos sinuosos rasos, posterior à ocorrência da erosão laminar (FERREIRA, 2004). É uma forma caracterizada por filetes de água que infiltram depois de curta distância, divididos em braços que se espalham e se juntam constantemente (CARVALHO, 2008). Apresentam profundidade e largura inferior a 50 centímetros com ruptura das bordas na superfície do terreno (DAEE/IPT, 1990), geralmente associados a trilhas de gado e a terrenos escarpados com solo exposto, podendo ser recuperados por operações normais de preparo de solo (MORGAM, 1986). Em alguns casos essa feição erosiva é imperceptível até que se interfira no preparo do solo em áreas agrícolas ou em novos loteamentos e ruas sem pavimentação (IDE, 2009). Sulcos são agentes de transporte de material já desagregado pelas chuvas ou outros fatores, com capacidade 
reduzida de arranque, existindo mesmo sobre uma cobertura vegetal (CARVALHO, 2008).

\section{Ravinas}

Ravinas são classificadas como sulcos alongados e estreitos com profundidade superior a 50 centímetros, não chegando a atingir o nível freático, associadas diretamente ao escoamento de água superficial. Raramente se ramificam, apresentam perfil transversal em "V" e seu avanço lateral ocorre através de movimentos de massa gravitacionais devido ao abatimento dos taludes (CANIL et al., 1995). É um processo erosivo mais intenso que o sulco, que ocorre quando o escoamento superficial se concentra em um determinado local, criando um canal preferencial (ARAUJO, 2011), geralmente a uma distância crítica do topo da encosta, podendo ser formados próximos à base por uma pequena incisão que recua contrário à queda da vertente (GUERRA; CUNHA, 2001). O desenvolvimento das ravinas pode estar associado à saturação do escoamento superficial (MORGAN, 1986).

O crescente desgaste do solo ao fundo da ravina, aumenta sua profundidade podendo, em alguns casos, atingir a rocha mãe (FOURNIER, 1960 apud ARAUJO, 2011). Quando a evolução do aprofundamento de ravinas atinge o nível freático, processos erosivos ligados à circulação das águas de sub-superfície passam a intervir, aumentando as dimensões do ravinamento. A este grau de evolução da erosão linear denominamos de voçoroca ou boçoroca (PONÇANO; PRANDINI, 1987).

\section{Voçorocas}

A palavra voçoroca ou boçoroca de origem etimológica do tupi-guarani ibi-çorok significa "terra rasgada" (HERRMANN; FRANCICANI; CAVALEIRO, 1994² apud FERREIRA, 2004), em alusão ao sulco ramificado de grande profundidade, de paredes irregulares e perfil transversal em "U", presente no solo em desacordo com a paisagem (CANIL et al., 1995).

No quadro evolutivo da erosão linear, a voçoroca constitui a feição erosiva mais avançada, complexa e destrutiva (DAEE/IPT, 1990; FOURNIER, 1960 apud ARAUJO, 2011), podendo ser formada através de uma passagem gradual da erosão laminar para a

\footnotetext{
${ }^{1}$ FOURNIER, F. Climat et erosion. França: Press Universitaires de France. 1960.

${ }^{2}$ HERRMANN, H.; FRANCICANI, E. M.; CAVALEIRO, F. Boçorocas: uma visão legal. In: Congresso Brasileiro de Geologia, 38, Balneário Camboriú (SC). Anais... São Paulo: SGB, 1994. p. 187-188.
} 
erosão em sulcos e ravinas cada vez mais profundas, ou então, diretamente por uma elevada concentração de fluxo de água sem a devida dissipação de energia (DAEE/IPT, 1990). A ação combinada das águas do escoamento superficial e sub-superficial, pela presença do lençol freático interceptado pela voçoroca, induz o aparecimento de minas d'água ao fundo e laterais da erosão. A liquefação do solo pelo surgimento de minas d'água pode ter uma continuidade para o interior do terreno, formando vazios no interior do solo em forma de tubos, processo conhecido como erosão interna ou piping. Quando estes vazios se tornam significativos ocasionam o colapso do terreno por desabamentos, escorregamentos e solapamentos (DAEE/IPT, 1990; INFANTI JUNIOR; FORNASARI FILHO, 1998; CARVALHO, 2008). Assim, todos os processos erosivos se conjugam no sentido de dotar esta forma de erosão de elevado poder destrutivo (DAEE/IPT, 1990), incontroláveis através de manejo por máquinas agrícolas comum (LAL, 1990; CANIL et al., 1995), impondo vários impactos negativos sobre as características do solo, culturas, e recursos hídricos em todo mundo (BOUAZIZ; WIJAYA; GLOAGUEN, 2009)

O desenvolvimento de uma voçoroca é dividido em dois estágios de acordo com as ações dos processos geomórficos. No primeiro, o qual corresponde a 5\% do tempo de vida de uma voçoroca, as ações hídricas de formação do canal são elevadas propiciando o intenso crescimento da erosão, principalmente de suas laterais. As características morfológicas do canal, comprimento, profundidade, largura, área e volume, estão longe de serem estáveis nesta fase de desenvolvimento da erosão. Estima-se que este período seja responsável pela formação de $90 \%$ do comprimento do rego, $60 \%$ da área de erosão e $35 \%$ do volume da vala (SIDORCHUK, 1999). Durante a segunda fase, que corresponde à maior parte do tempo de vida da erosão, sua evolução é morfologicamente estável, com menor remoção de material, surgimento de um pequeno curso d'água em seu interior e o crescimento de vegetação (SIDORCHUK, 1999; IDE, 2009). A tendência de estabilidade do processo ocorre quando o leito atinge o nível de base local ou substratos rochosos mais resistentes (IDE, 2009).

Poesen et al. (2003) afirmam que as erosões em sulco podem contribuir entre $10 \mathrm{a}$ 94\% do sedimento produzido nas bacias hidrográficas.

\subsubsection{Dinâmica de erosão}

A erosão, responsável pela produção de sedimentos em uma bacia hidrográfica, se inicia com a separação e remoção da partícula da rocha e do solo pela ação da água, do 
vento ou por outro efeito de degradação da superfície do terreno. O desprendimento da partícula no processo de erosão hídrica ocorre através da energia cinética de impacto da gota da chuva sobre a superfície desprotegida do solo e pelas forças geradas devido à ação do escoamento das águas (CARVALHO, 2008; WIRTZ; SEEGER; RIES, 2012). Em solos protegidos por vegetação arbórea, dependendo da forma e distribuição das copas e do tamanho das árvores, a energia cinética resultante do impacto da gota de chuva no solo pode ter uma redução de até 59\% (GEIßLER et al., 2012).

Estando a partícula solta, esta é deslocada de sua posição, podendo ser transportada pelas enxurradas para os cursos d'água ou depressões no terreno. A forma, tamanho, peso da partícula e forças exercidas pela ação do escoamento são fatores determinantes da condição de transporte ou deposição do sedimento. Condições desfavoráveis ao deslocamento das partículas nos leitos fluviais provocam a deposição dos fragmentos de solo no fundo e laterais do canal, conhecida como assoreamento dos cursos d'água (CARVALHO, 2008).

\subsubsection{Agentes erosivos e condicionantes da erosão linear}

Os agentes erosivos, elementos do meio físico que causam, ou afetam, diretamente a erosão, são classificados em agentes passivos e agentes ativos. Os passivos são aqueles que não atuam diretamente nos processos de erosão, porém colaboram no desencadear do processo, como, por exemplo, topografia, gravidade, o tipo de solo, a cobertura vegetal, as formações superficiais e as ações antrópicas. Já os agentes ativos contribuem diretamente em todas as etapas do processo erosivo. São eles: a água, temperatura, insolação, vento, gelo, neve, ação de microorganismos e ainda a ação humana (CARVALHO, 2008).

A exemplo dos quatro principais agentes erosivos naturais e mais atuantes para o surgimento e desenvolvimento de erosões lineares em regiões tropicais e sub-tropicais, podemos destacar a chuva, o solo e natureza do substrato rochoso, a geomorfologia e o uso e ocupação do solo, fatores erosivos que não agem de forma independente no desencadear do fenômeno erosivo (MORGAN, 1986; DAEE/IPT, 1990; FERREIRA, 2004; IDE, 2009). Estes fatores são diretamente responsáveis pela variação nas taxas de erosão do terreno (GUERRA; CUNHA, 2001). 


\subsection{Erosividade da chuva}

A aceleração do desenvolvimento de um processo erosivo linear causada pela ação da chuva, está diretamente relacionada com as características de intensidade, duração e frequência das precipitações(DAEE/IPT, 1990). O efeito desagregador de solo, promovido pelo impacto das gotas de chuva no terreno e o acúmulo de água e desencadeamento de transporte de sedimentos pelas enxurradas, pode ser maior ou menor de acordo com estas características (INFANTI JUNIOR; FORNASARI FILHO, 1998; GUERRA; CUNHA, 2001).

Em épocas chuvosas quando o volume de água das chuva (intensidade) é muito elevado durante um longo período de precipitação (duração) e com alta frequência no tempo, o espaço disponível para a infiltração de água no solo e o acúmulo em depressões no terreno é saturado, propiciando o desenvolvimento de enxurradas agressivas à estabilidade dos solos (GUERRA; CUNHA, 2001). Chuvas torrenciais ou pancada de chuvas intensas associadas a altas velocidades de enxurrada, constituem a forma mais agressiva de impacto da água no solo, elevando o índice de erosão ao máximo, criando condições favoráveis ao avanço extremamente rápido de ravinas e voçorocas (DAEE/IPT, 1990; FERREIRA, 2004).

Apesar de, em feições erosivas lineares avançadas, como as voçorocas ou boçorocas, o processo dominante no avanço destas erosões ser o escoamento superficial, o aumento do fluxo de água no sub-solo, propiciado durante os períodos chuvosos, também elevam as taxas de erosão sub-superficiais como piping e escorregamentos (IDE, 2009).

\subsection{Erodibilidade do solo}

O solo é o fator precípuo inerente ao processo erosivo por influenciar e sofrer a ação da erosão (MIRANDA, 2005). A erodibilidade do solo ou o grau de facilidade dos solos de serem erodidos, fixando os demais fatores ou agentes, determina a suscetibilidade dos terrenos a sofrerem erosão (DAEE/IPT, 1990; IDE, 2009), seja, principalmente, pela influência de suas propriedades físicas como textura, estrutura, permeabilidade e densidade, ou pelas propriedades químicas, biológicas e mineralógicas (LAL, 1990; GUERRA; CUNHA, 2001; MIRANDA, 2005; CARVALHO, 2008). Tal diversidade de parâmetros dificulta suas correlações e a afirmação de uma metodologia ideal na determinação da erodibilidade dos solos, sendo, portanto, poucos os métodos de análise 
desenvolvidos (IDE, 2009). No entanto, desconsiderando a mutabilidade das propriedades do solo em um determinado período de tempo (GUERRA; CUNHA, 2001), a identificação e classificação dos solos pela pedologia, com base no conjunto de suas características, resume seu comportamento frente à erosão (DAEE/IPT, 1990).

As principais áreas de ocorrência de voçorocas no Brasil são as regiões de formações geológicas sedimentares, cuja pedologia corresponde a solos arenosos como: podzólicos e latossolos (INFANTI JUNIOR; FORNASARI FILHO, 1998).

\subsection{Geomorfologia}

O relevo é o fator erosivo associado à velocidade adquirida pelo escoamento superficial, fundamental no surgimento de processos erosivos (DAEE/IPT, 1990). A influência da geomorfologia do terreno ocorre, principalmente, pela declividade e comprimento de rampa (INFANTI JUNIOR; FORNASARI FILHO, 1998). O desencadeamento de erosões em relevos acidentados é mais esperado do que em relevos suaves, pois a velocidade e concentração atingidas pela água em relevos acidentados são mais propícias do que em regiões planas (DAEE/IPT, 1990). Em alguns casos de elevada declividade, a chuva escoa tão rapidamente que não há infiltração, provocando um maior esforço no terreno (CARVALHO, 2008). Já o comprimento de rampa está diretamente associado à energia potencial gravitacional disponível, que favorece a aceleração da enxurrada, quanto mais extenso for o percurso da água no talvegue.

A forma do relevo é outro fator não menos importante na determinação do surgimento de processos erosivos. Encostas com o perfil convexo são mais suscetíveis ao surgimento e desenvolvimento de voçorocas, principalmente as que apresentam as curvas de nível côncavas ou coletoras, concentrando o escoamento superficial em um único canal. O perfil côncavo de encostas, seja com curvas de nível côncavas ou convexas, são menos propensas ao desenvolvimento de erosões lineares (RODRIGUES, $1982^{3}$ apud MIRANDA, 2005).

\subsection{Uso e ocupação do solo}

A produção de sedimentos nas bacias hidrográficas também tem suas origens nos processos erosivos decorrentes do mau planejamento do uso e ocupação do solo. Solos

\footnotetext{
${ }^{3}$ RODRIGUES, J. E. Estudo de fenômenos acelerados: Boçorocas. 1982. 162 f. Tese (Doutorado) - Escola de Engenharia de São Carlos, Universidade de São Paulo, São Carlos, 1982.
} 
desnudos ou com baixa proteção em regiões tropicais, onde a pluviosidade é mais frequente e intensa, são frequentemente erodidos pela ação da água da chuva que desagrega e lava o solo exposto e, por consequência, transporta este material ao leito dos rios que drenam a bacia hidrográfica.

Trabalhos como os desenvolvidos por Morais et al. (2004), Ferreira et al. (2005), Sobral et al. (2006), Casalí et al. (2006), Silva et al. (2007), Lucena et al. (2007), Valério et al. (2008), Descroix et al. (2008), Henrique (2009) e Ide (2009) abordam o mau planejamento do uso e ocupação do solo como precursor no aumento dos índices de aporte de sedimentos nos recursos hídricos.

Ide (2009), por exemplo, estudou a interferência do uso e ocupação do solo na aceleração do processo erosivo a partir da análise de ensaios in situ e em laboratório, afirmando que a evolução das erosões urbanas em Bauru (SP) tem seu processo agravado com o desmatamento, impermeabilização do solo e deságue de águas pluviais e esgoto devido a projetos inadequados e falta de infra-estrutura de drenagem. Da mesma forma nas áreas rurais, Descroix et al. (2008) também relataram o efeito do desmatamento e do uso e ocupação do solo como precursores no processo de erosão laminar e por sulcos em regiões montanhosas da bacia hidrográfica do rio Nazas, México. Casalí et al. (2006) afirmam que sulcos e ravinas são comuns em áreas de cultivo e pastagem ao redor do mundo e podem causar grandes perdas de solo. Morais et al. (2004) ressalvam em seus estudos que embora os processos superficiais relacionados ao escoamento superficial e ao uso e ocupação do solo sejam cruciais, os processos sub-superficiais, como mineralogia e textura, também são importantes na determinação do surgimento de ravinas e voçorocas, principalmente relacionados a formação de piping que aceleram estes tipos de processos erosivos.

Henrique (2009), por outro lado, utilizou o manejo adequado do uso do solo e do reflorestamento na busca de soluções para evitar a erosão hídrica e o aumento das cargas poluidoras difusas, aumentando a disponibilidade e qualidade de água. Quando aplicadas a montante das bacias hidrográficas, estas técnicas beneficiam, por consequência, usuários de água a jusante da bacia. Os percentuais de redução de sedimentação para um cenário com aumento de $20 \%$ da área florestal das bacias, segundo o autor, podem chegar à ordem de $35 \%$. 


\subsubsection{Métodos de avaliação dos processos erosivos}

Apesar da preocupação com a problemática da erosão ser anterior ao século XX, foi neste século que as investigações sobre a erosão hídrica e as técnicas para avaliar as perdas de solo começaram a ser desenvolvidas e empregadas (CARVALHO, 2008).

Dependendo dos objetivos da investigação científica que queremos empreender, da natureza do problema que se deseja conhecer ou estudar, devemos escolher e empregar as metodologias que mais nos ajudam na compreensão do fenômeno. De modo geral, as metodologias de pesquisa científica são divididas em qualitativas e quantitativas que não se substituem, mas se complementam. Da mesma forma, as metodologias de avaliação dos processos erosivos se dividem nestes dois tipos, com intuito de analisar os fenômenos sobre os diversos aspectos de seu desenvolvimento (SILVA, 2003), sendo a qualitativa voltada para a análise das formas e grau das erosões, e a quantitativa para as características pertinentes do sistema (ALMOROX et al., $1994^{4}$ apud ARAUJO, 2011).

Tabela 1. Metodologias de avaliação de erosão hídrica.

Método Qualitativo

Formas de erosão

Graus de erosão

\begin{tabular}{lc|c}
\hline & \multicolumn{2}{c}{ Avaliação direta } \\
\cline { 2 - 3 } Método Quantitativo & Modelo físico \\
& Avaliação indireta & Modelo estatístico \\
& Modelo paramétrico \\
\hline
\end{tabular}

Fonte: Almorox et. al. (1994 apud ARAUJO, 2011).

\subsubsection{Método qualitativo}

Métodos qualitativos utilizam, principalmente, a foto interpretação dos dados de sensoriamento remoto para analisar diferentes características que determinam os processos erosivos de uma região (BOUAZIZ; LEIDIG; GLOAGUEN, 2011). Os resultados obtidos, que não se utilizam de valores numéricos, devem ser confrontados com levantamentos de campo, necessário à comprovação da análise realizada (ALMOROX et al., 1994 apud ARAUJO, 2011). A aprovação dos resultados obtidos é de fundamental importância para operacionalizar sistemas de monitoramento regionais, porém a falta de dados para validação ainda é motivo de preocupação (VRIELING, 2006).

\footnotetext{
${ }^{4}$ ALMOROX, J. et. al. Métodos de estimación de la erosión hídrica. España: Agrícola Española. 1994.
} 


\subsubsection{Método quantitativo}

O método quantitativo, diferente do qualitativo, analisa os processos erosivos com base em números (ARAUJO, 2011), que representam as características de tendências observáveis, geralmente apropriado quando há possibilidades de coleta de medidas quantificáveis a partir da amostra de uma população.

A quantificação de determinados parâmetros pode ser obtida através de avaliações diretas ou indiretas, dependendo da disponibilidade física, de tempo e recursos para sua execução, traduzindo em números as opiniões e informações a serem classificadas e analisadas.

\subsection{Avaliação direta}

$\mathrm{Na}$ avaliação direta, os parâmetros de análise são coletados a partir de experimentos realizados diretamente na área de estudo, também chamados de experimentos in situ. Com base em ensaios de solo, simuladores de chuva, mensuração de características físicas e medidas de parâmetros junto aos sedimentos no solo, como Cs137 (KONZ; PRASUHN; ALEWELL, 2012), matéria orgânica e fósforo, é possível estimar os fatores de erosão (ALMOROX et al., 1994 apud ARAUJO, 2011) e quantificar a perda de solo.

Wirtz, Seeger e Ries (2012), por exemplo, criaram e utilizaram uma nova metodologia de campo para quantificar a perda de sedimentos provocada pelas erosões em sulco. A pesquisa concentrava o escoamento de uma vazão de água conhecida em um trecho do terreno em estudo, e coletava o material arrastado pela enxurrada para quantificação. $\mathrm{O}$ estudo demonstrou que a variação de material carreado pode ser de 5 a $440 \mathrm{~g} \cdot \mathrm{L}^{-1}$ de água escoada, e que os resultados obtidos não são explicados pelas equação de perda de solo existentes.

A existência de pouca informação disponível sobre a precisão dos diferentes métodos por medições diretas utilizados na determinação de volume de sulcos e voçorocas no campo (WIRTZ; SEEGER; RIES, 2012), foram a base dos estudos realizados por Casalí et al. (2006) para avaliar adequadamente a erosão do solo em áreas agrícolas. Considerando a importância deste tipo de erosão, métodos de medição para determinar com precisão o volume de sulcos e voçorocas efêmeras são 
obrigatórios. Métodos atuais podem chegar a um erro médio de até $12 \%$ segundo os autores.

Apesar da influência desta classe de erosão na degradação do solo ser de grande relevância, a falta de métodos adequados para a documentação e monitoramento, além da realização de poucos experimentos na área, resultou na baixa confiança e escassez de dados quantitativos para compreender o papel dos sulcos na erosão do solo (MARZOLFF; POESEN, 2009; WIRTZ; SEEGER; RIES, 2012).

\subsection{Avaliação indireta}

A avaliação indireta consiste em quantificar os processos erosivos através do uso de modelos que simplificam a realidade do sistema natural, com auxílio de cálculos computacionais e banco de dados de informações. Estes modelos podem ser estatísticos, físicos e paramétricos (ALMOROX et al., 1994 apud ARAUJO, 2011).

As primeiras fórmulas que estimavam a perda de solo foram desenvolvidas com poucos parâmetros e para regiões específicas em estudo. No decorrer do aumento de informações sobre erosões como características de escoamento da água, dinâmica de erosões, comportamento de agentes erosivos, permitiram o melhoramento das equações empíricas anteriores e a definição da primeira equação universal da perda de solo na década de 1960. Posteriormente na década de 70, os primeiros modelos aplicáveis na escala de bacia hidrográfica começaram a surgir como o modelo hidrológico HYMO e a equação de transporte de William (CARVALHO, 2008).

As equações que quantificam a perda de solo se mostraram úteis para estudos de controle de erosão, apesar da probabilidade de erros grosseiros na sua determinação, no entanto, estas fórmulas e modelos se referem a uma erosão ocorrida em sua maior parte como erosão laminar. Modelos específicos foram desenvolvidos para a previsão de outros tipos de erosão como em leitos de rios ou voçorocas (CARVALHO, 2008). As principais fórmulas empregadas avaliam o avanço linear anual da cabeceira do barranco (THOMPSON, $1964^{5}$ apud CARVALHO, 2008; UNIVERSIDAD POLITÉCNICA DE MADRID, $1984^{6}$ apud CARVALHO, 2008), a superfície de crescimento dos barrancos

\footnotetext{
5 THOMPSON, J. R. Quantitative effect of watershed variables on rate of gully head advancement. Transactions of the American Society of Agricultural Engineers, Ed. 7, p. 54 - 55, 1964.

${ }^{6}$ UNIVERSIDAD POLITÉCNICA DE MADRID. Metodologia para la evaluación de la erosión hídrica. Madrid: Departamento de Hidráulica e Hidrologia de la Escuela Técnica Superior de Ingenieros de Montes, 1984.
} 
(BEER; JOHSON, $1963^{7}$ apud CARVALHO, 2008), e o volume de sedimentos produzidos pelas erosões na rede de drenagem (WILLIAMS, $1975^{8}$ apud CARVALHO, 2008). Trabalhos desenvolvidos com estes tipos de erosão demonstram que a quantidade de sedimento desprendido destas feições erosivas são relevantes.

Rijsdijk et al. (2007) estimaram a contribuição de sedimentos de voçorocas na Indonésia como sendo superior a $10 \%$ dos sedimentos totais encontrados na foz da bacia hidrográfica do Konto e Ndomba et al. (2009) estimaram a contribuição da produção de sedimentos de uma voçoroca na região nordeste da Tanzânia levando em consideração 10 parâmetros ambientais e ferramentas computacionais, chegando a um montante de 6.800 t/ano, aproximadamente $1,6 \%$ do total de sedimentos encontrados na foz do rio Pangani, principal drenagem da bacia de estudo. Ambos os estudos demonstram a importância da contribuição de sulcos e voçorocas no montante final de sedimentos transportados nas bacias hidrográficas.

Casasnovas (2003) explica que as voçorocas têm um elevado grau de expansão lateral em relação ao recuo de sua cabeceira ou avanço linear devido à falta de estabilidade das paredes laterais da cavidade. A erosão provocada pela ação de fricção da drenagem na base dos barrancos em conjunto com a ação da gravidade leva ao contínuo desmoronamento das laterais e alargamento da voçoroca. Os sedimentos desprendidos em grandes massas das paredes geralmente são removidos pela água após chuvas de alta intensidade contribuindo significativamente para o aumento do nível de sedimentos em suspensão nos corpos d'água receptores. Apenas em poucos casos os sedimentos são depositados nas paredes ou no fundo da voçoroca, podendo levar a certo grau de estabilização da erosão (BRAYSHAW; HASSAN, 2009). Com isso, Casasnova (2003) desenvolveu na Catalunha, Espanha, uma metodologia para a determinação da taxa de desbarrancamento das laterais de voçorocas, assim como o estudo de modelagem de Zinck et al. (2001), com base em tecnologias de sistemas de informações geográficas (SIG), modelagem digital de elevação (DEM) e sensoriamento remoto, como princípio para o cálculo da contribuição na produção de sedimentos. Comparando seus resultados com os obtidos por outros pesquisadores, Casasnovas (2003) afirmou que a contribuição na produção de sedimentos por voçorocas está longe de ser desprezível e que, apesar dos

\footnotetext{
${ }^{7}$ BEER, C. E.; JOHNSON, H. P. Factors related to gully growth in the deep loess area of western Iowa. Proceedings of the Federal Inter-Agency Sedimentation Conference, Miscellaneous Publications, p. 37 43, 1970.

${ }^{8}$ WILLIAMS, J. R. Sediment-yield prediction with universal equation using run off energy factor. Present and Prospective Technology for Predicting Sediment Yields and Sources. USDA-ARS-S-40, p. 244 - 252, 1975.
} 
esforços que tem sido empregados para investigar os processos erosivos nas últimas décadas, relativamente poucos estudos têm sido focados na quantificação e/ou modelagem de voçorocas.

Posteriormente, Torri et al. (2006) demonstraram que a relação largura do canal com a descarga de fundo aplicada a córregos pode ser aplicada a sulcos e voçorocas. Após alguns ajustes nas fórmulas comumente utilizadas, os autores desenvolveram uma nova metodologia da relação aplicada a estes tipos de erosão. Outros trabalhos como o de Marzolff e Poesen (2009) e Bouchnak et al. (2009) desenvolveram novas metodologias sobre a produção de sedimentos em voçorocas com uso integrado de fotografias aéreas e sistemas de informações geográficas (SIG).

As Nações Unidas reconhecem (PEART; WALLING, $1988^{9}$ apud NDOMBA et al., 2009) que dados de medições de campo com métodos diretos do volume do material erodido são mais úteis (BERTONI; NETO, 2008) e confiáveis para usos em estimativas de contribuição de produção de sedimentos por voçorocas, no entanto, as dificuldades associadas ao tempo e orçamento necessários à realização destes levantamentos ainda favorecem o uso e determinação de métodos indiretos pelos pesquisadores para quantificação volumétrica (KOMPANI-ZARE et al., 2011)

\subsubsection{Equação Universal da Perda de Solo - EUPS}

Levando-se em conta os agentes erosivos e seus fatores, Wishmeier e Smith (1978) desenvolveram a primeira Equação Universal de Perdas de Solo (EUPS) para estimativa da erosão laminar em termos médios anual, posteriormente melhorada por outros pesquisadores, passando a ser a fórmula mais empregada nesta determinação (CARVALHO, 2008).

O uso da EUPS para avaliar as perdas de solo de uma área cultivada vem se tornando prática indispensável para o planejador conservacionista (BERTONI; NETO, 2008). Exemplos de uso desta fórmula podem ser encontrados nos trabalhos de Mansor et al. (2002), que estudaram o "comprimento da rampa", componente do fator LS da Equação Universal de Perdas de Solo, como parâmetro de avaliação do potencial de risco de erosão. Da mesma forma, Guimarães e Santos (2007), baseados nas características pedológicas, do relevo e do uso e ocupação, fizeram um diagnóstico do potencial à erosão

\footnotetext{
${ }^{9}$ PEART, M. R.; WALLING, D. E. Techniques for establishing suspended. In: BORDAS, M. P., WALLING, D. E. (Eds.), Sediment Budgets Proceedings of the International Symposium. IAHS Press, Ed. 174, p. 269 279,1988
} 
laminar da bacia hidrográfica da represa Piraquara I, responsável por abastecer a região metropolitana de Curitiba (PR), como uma ferramenta de suporte a detecção de áreasfonte ao assoreamento da barragem.

Vanmaercke et al. (2011) utilizaram dados históricos de sedimento em suspensão, batimetria de reservatórios e lagos e de trabalhos de sedimentologia desenvolvidos para a realidade Européia, bem como dados climatológicos, de solo, de topografia e uso e ocupação do solo de toda a Europa, como dados de entrada para modelar a produção de sedimento em todo o continente europeu. Os resultados apontam que na porção ocidental, setentrional e central, apresentam baixa produção de sedimentos, enquanto que a região mediterrânea e de montanhas, taxas maiores. No entanto, os próprios autores concordam que os dados são muito vastos e que diversos erros podem estar embutidos no resultado final.

A confiabilidade da EUPS e outras técnicas foram contestadas por Souza et al. (2006) a partir de estudos e comparações das metodologias mais utilizadas de estimativa de produção de sedimentos, averiguando uma diferença de magnitude nos resultados em até 41 vezes, na bacia do rio Potiribu (RS).

\subsubsection{Deposição de sedimentos}

\subsubsection{Definição}

As represas são ambientes lacustres provenientes do barramento artificial de cursos d'água, que tem como objetivo o armazenamento de água, seja para obtenção de um volume adequado às diversas utilizações como abastecimento de água para centros urbanos, indústrias e irrigação, seja para garantir uma altura de queda d'água suficiente para a geração de energia (SPERLING, 1999).

As barragens são construídas pela civilização humana a mais de 4500 anos. Devido às limitações de conhecimento na área de construção, suas represas de armazenamento de água eram modestas, causando um impacto local relativamente pequeno. Com a aplicação de materiais mais resistentes e desenvolvimentos de novas técnicas de construção, as barragens e volume de água retidos passaram a ser maiores, agravando, consequentemente, os problemas decorrentes (STERNBERG, 2006) das modificações físicas (KRASA et al., 2005; WANG; HU, 2009; GUOZHONG et al., 2010; HUA; YANG, 2011), ambientais (CHETTRI; BOWONDER, 1983; WANG; HU, 2009) e 
sociais (BERMANN, 2007; WANG; HU, 2009) nos locais em que são instalados (MIRANDA, 2011).

O processo de assoreamento das represas em todo o mundo é a consequência dos processos erosivos na bacia hidrográfica (HAREGEWEYN et al., 2012) e está diretamente relacionado às condições de transporte de sedimentos exercido pelas águas do rio represado. A queda acentuada ou eliminação da turbulência do fluxo d'água afluente ao reservatório devido ao aumento da sessão transversal corrente, ocasionada pelo enchimento da barragem, diminui drasticamente a velocidade da água, reduzindo as forças exercidas pela ação do escoamento (MAIA; VILLELA, 2009). Quando estas forças se reduzem até a condição de não poderem continuar a deslocar as partículas de sedimento, ocorre o processo de deposição/assoreamento do canal (CARVALHO, 2008). Assim, os reservatórios seguem o mesmo princípio das caixas de areia nos processos de tratamento de água e efluentes, funcionam como armadilhas de sedimento (THOTHONG et al., 2011), modificando o equilíbrio sedimentológico dos cursos d'água.

O conhecimento do processo de sedimentação em reservatórios é de interesse global para a gestão da água, uma vez que este fenômeno reduz gradualmente a capacidade de retenção de água nestes ambientes (CHETTRI; BOWONDER, 1983; LU et al., 2010).

Os primeiros estudos internacionais relacionados ao problema de assoreamento de reservatórios de águas continentais se iniciaram com os trabalhos de Fiock (1934) ${ }^{10}$, Grover e Howards (1938) ${ }^{11}$ e Eakin (1939) ${ }^{12}$ e no Brasil apenas em meados de 1980 com os estudos de Ponçano et al. $(1981)^{13}$, Gimenez et al. $(1981)^{14}$ e Caristron Filho et al. $(1981)^{15}$ (CARVALHO, 2000).

\footnotetext{
${ }^{10}$ FIOCK, L. R. Records of silt carried by the Rio Grande and its accumulation in elephant butte reservoir. American Geophysical Union, Ed. 15, p. 468 - 473, 1934.

${ }^{11}$ GROVER, H. G; HOWARDS, C. S. The passage of turbid water through lake mead. Tran ASCE, Ed. 103, p. $720-736,1938$.

${ }^{12}$ EAKIN, H. M. Silting of reservoirs, revised by Brow, C. B. Dept Agricultura. Tech Bulletin, Ed. 524, p. 90 167, 1939.

${ }^{13}$ POÇANO, W. L.;GIMENES, A. F.; LEITE, A. A. G.; CARLSTRON FILHO, C; PRADINI, F. L.; MELO, M. S. de. Metodologia para estudo de assoreamento de reservatório (III): roteiro para estudo de reservatórios no sul e sudeste brasileiro. IN: CBGE, 3, Itapema (SC). Anais... São Paulo: ABGE, V2, 1981. p. 331 - 353.

${ }^{14}$ GIMENEZ, A. F.; CARLSTRON FILHO, C.; CARNEIRO, C. D. R.; STEIN, D. P.; PRADINI, L. F.; MELO, M. S.; FULFARO, V. J.; PONÇANO, W. L. Metodologia de estudo de assoreamento de reservatórios (I) Reservatório de Capivari (PR). In: CBGE, 3, Itapema (SC). Anais... São Paulo: ABGE, 1981. p. 205 - 224.

${ }^{15}$ CARLSTRON FILHO, C.; GIMENEZ, A. F.; PIRES NETO, A. G.; PRADINI, L. F.; MELO, M. S.; FULFARO, V. J.; PONÇANO, W. L. Metodologia para estudo de assoreamento de reservatórios (II) Reservatório de Passo Real e Ernestina (RS). In: CBGE, 3, Itapema (SC). Anais... São Paulo: ABGE, 1981. p. $143-162$.
} 
Em trabalhos realizados por Mahmood $(1987)^{16}$ para reservatórios em todo o mundo e, posteriormente, pela Eletrobrás e Instituto de Pesquisas Hidráulicas Eletrobrás/IPH (1992) ${ }^{17}$ para reservatórios brasileiros, foram estimadas as taxas médias anuais de perda de volume dos reservatórios, devido ao assoreamento, em $1 \%$ mundialmente, com variação de um local para outro, e 0,5\% para os reservatórios brasileiros (CARVALHO, 2008). Para estudos realizados na China, a taxa encontrada é de 2,3\% de perda média ao ano (WANG; HU, 2009).

No entanto, quando não há estudos prévios do aporte de sedimentos nos corpos d'água a serem represados, nem o controle dos processos erosivos no entorno das represas, a experiência histórica comprova que reservatórios podem ser parcialmente ou completamente assoreados em poucos anos após o seu enchimento. Este quadro de más práticas conservacionistas, associado ao aumento das intensidades das chuvas provocado pelas mudanças climáticas, tende a aumentar e agravar os casos de assoreamento de reservatórios de águas continentais (THOTHONG et al., 2011).

Chettri e Bowonder (1983), por exemplo, apontam que o acompanhamento regular do assoreamento e a tomada de medidas corretivas em tempo oportuno, teriam reduzido a extensão dos danos por assoreamento no reservatório Nizamsagar, Índia, que teve $60 \%$ do seu volume assoreado em apenas 40 anos.

Kertész e Gergely (2011) estudaram as causas erosivas no assoreamento completo dos $95.300 \mathrm{~m}^{3}$ de uma represa, na bacia de Tetves - Hungria. A represa foi construída em 1970 e assoreada completamente no ano 2000, período em que já se tinha conhecimento da importância do planejamento sedimentológico.

Haregeweyn et al. (2012) estudaram o assoreamento precoce da represa Angereb na Etiópia. O reservatório foi construído em 1997, projetado para abastecer a população local durante 25 anos. No entanto, estudos batimétricos demonstraram a possibilidade do completo assoreamento do lago ao final do ano de 2011, totalizando apenas 15 anos de vida útil da represa.

Estudos revelaram que 8 bilhões de metros cúbicos disponíveis em 20 grandes reservatórios para armazenamento de água na China, até o ano de 1985, foram

\footnotetext{
${ }^{16}$ MAHMOOD, K. Reservoir Sedimentation - Impact, Extent and Mitigation. Washington, DC: World Bank Technical Paper Number 71, 1987.

${ }^{17}$ ELETROBRÁS/IPH. Diagnóstico das condições sedimentológicas dos principais rios brasileiros. Rio de Janeiro: Eletrobrás, 1992, 100 p.
} 
comprometidos com o processo de deposição de sedimentos em seus leitos, equivalente a 66\% do volumes destes reservatórios (IRTCES, $1985^{18}$ apud WANG; HU, 2009).

A exemplo dos casos dos reservatórios brasileiros, Carvalho e Lôu (1986) relatam o assoreamento precoce do reservatório da UHE de Mascarenhas localizada no Rio Doce ES. A usina foi projetada para regularizar uma vazão de $600 \mathrm{~m}^{3} / \mathrm{s}$, no entanto a realidade demonstrou que na maior parte do tempo a vazão permanecia em $400 \mathrm{~m}^{3} / \mathrm{s}$. O erro de cálculo associado à grande quantidade de sedimentos presente nas águas do Rio Doce provocou o assoreamento precoce do reservatório da UHE Mascarenhas.

Carvalho (2008) destaca os reservatórios de Três Marias (Rio São Francisco), Funil (Rio Paraíba do Sul), Barra Bonita (Rio Tietê) e Capivara (Rio Paranapanema), entre tantos outros relatados em seus estudos, como parcialmente assoreados, porém sem apresentar problemas evidentes na sua operação. Outros estudos históricos referentes ao assoreamento de represas no Brasil e no mundo foram relatados por Miranda (2011).

\subsubsection{Dinâmica e tipos de deposição}

O estudo do assoreamento de reservatórios é muito complexo devido aos diversos fatores que influenciam na deposição do sedimento. Alguns dos mais importantes são: a extensão e a forma física dos reservatórios, razão entre a capacidade do reservatório e tamanho da bacia hidrográfica ou deflúvio afluente, geomorfologia da bacia hidrográfica, densidade da rede de canais, uso e ocupação do solo, e características físicas e químicas do sedimento afluente (DENDY, 1986).

A distribuição dos depósitos de sedimentos no interior dos reservatórios é observada a montante e a jusante do curso d'água represado, sendo averiguada maior intensidade e alterações mais evidentes na região a montante da represa e em exutórios de afluentes (ALCÂNTARA et al., 2010). Todos os tributários de reservatórios tendem a desenvolver a formação de deltas em resposta a queda da velocidade do fluxo d'água, influenciando a formação de pequenas ilhas e baias (CHETTRI; BOWONDER, 1983; STERNBERG, 2006).

Portanto, o início do processo de deposição se dá na interface rio/lago onde ocorrem os chamados depósitos de remanso cujas partículas características são de grande diâmetro (TEIXEIRA, 2008).

\footnotetext{
${ }^{18}$ INTERNATIONAL RESEARCH AND TRAINING CENTER ON EROSION AND SEDIMENTATION. Lecture notes of the training course on reservoir sedimentation. China: Series of publication, 1985.
} 
Conforme se avança em direção a barragem da represa, a seção transversal da área molhada tende a aumentar, diminuindo ainda mais a velocidade do escoamento e a presença de turbulências que revolvem o sedimento depositado. $\mathrm{O}$ aumento das condições descritas associadas à presença física da barragem que impede a passagem das partículas, favorecem a deposição de materiais mais finos como siltes e argilas, formando o chamado depósito de leito ou de fundo. Assim os depósitos na entrada do reservatório são mais frequentes e formados por sedimentos mais grossos enquanto que os depósitos mais próximos a barragem com sedimentos finos.

No entanto, a distribuição dos sedimentos em reservatórios não segue um padrão uniforme, variando em três origens de depósitos: depósito de remanso, delta e depósito de fundo (CARVALHO, 2008).

Os depósitos de remanso, como já mencionado, ocupam as regiões de entrada do reservatório e são formados por sedimentos de granulometria maior. O assoreamento destas áreas não altera a capacidade útil do reservatório, no entanto, pode prejudicar a navegabilidade do canal (WANG; HU, 2009; HUA; YANG, 2011) e provocar o fenômeno hidráulico conhecido como remanso, intensificando problemas de enchentes a montante do reservatório (CARVALHO, 2008).

Os deltas são depósitos formados no interior do reservatório por diversas granulometrias, predominando, no entanto, materiais mais grossos como areia. Os sedimentos neste tipo de assoreamento ocupam o volume morto do reservatório, volume previsto para o depósito de materiais em suspensão, mas sua principal consequência ao reservatório é a redução gradativa do volume útil, ou volume destinado à regularização da vazão para melhor aproveitamento e gerenciamento dos usos múltiplos das represas. Ou seja, os assoreamentos delta são os principais responsáveis pela alteração das características de funcionamento do reservatório, resultando em perdas econômicas, por exemplo, na geração de energia (MIRANDA, 2011).

Por último, mas não menos importante, os depósitos de fundo são formados por materiais mais finos como silte e argila, e se localizam nos trechos mais profundos do reservatório, próximos à barragem (ALCÂNTARA et al., 2010), região conhecida como volume morto do reservatório. Estes depósitos, quando ultrapassam o volume destinado ao assoreamento, passam a interferir na tomada d'água para geração de energia (CARVALHO, 2008; WANG; HU, 2009; MIRANDA, 2011). 
Carvalho (2008) ainda menciona a formação de depósitos de várzeas, gerados pela ação das enchentes, e depósitos de sedimento nas margens ou depósitos de margem, gerados pela ação das ondas das represas e vento. Este último foi estudado posteriormente por Ma et al., (2010) que criaram um modelo 2D para analisar a relação das ondas e gravidade no processo de deposição em Waiapu shelf, Nova Zelândia.

\subsubsection{Métodos de avaliação do processo de deposição}

Os estudos sedimentológicos devem ser conduzidos em todas as fases do aproveitamento, desde o planejamento até a operação dos reservatórios, a fim de se prever e minimizar os efeitos depreciativos do sedimento a montante e a jusante da barragem. Os detalhes dos estudos devem ser maiores quanto forem os problemas de erosão, transporte e assoreamento que se apresentarem na bacia hidrográfica(CARVALHO, 2008).

Para novos empreendimentos, quando ainda não há interferência do barramento no curso d'água, as fases de estudo do assoreamento são divididas em três etapas: fase de inventário, fase de viabilidade e de projeto básico e fase de operação.

O inventário é a fase onde se reúnem os dados existentes das redes de postos hidrossedimentológicos. No Brasil, apesar dos dados serem antigos e não espelharem a realidade atual da erosão na bacia hidrográfica, podem servir como informações para comparação e quantificação da variação das taxas de erosão com dados atuais. Quando não existentes, dados de bacias vizinhas com as mesmas características podem ser utilizados desde que criteriosamente justificado. Os estudos iniciais de assoreamento indicarão as necessidades de controle de sedimentos no empreendimento e as necessidades construtivas do projeto da barragem e de concepção de estruturas hidráulicas como desarenadores e descarregador de fundo, para fins de gestão (CARVALHO, 2008; LU et al., 2010). Estas informações iniciais são utilizadas em diferentes modelos empíricos e numéricos para determinar a quantidade total de deposição, assim como o padrão e distribuição de depósitos em um reservatório (LU et al., 2010).

$\mathrm{Na}$ segunda etapa, ou fase de viabilidade e de projeto básico são utilizadas as conclusões da fase de inventário para refinar e desenvolver trabalhos mais consistentes, empregando, principalmente, modelos matemáticos que darão respostas mais definitivas como efeito do assoreamento no remanso e efeitos a jusante da barragem. Nesta fase é que são definidos os arranjos das obras e intervenções necessárias ao controle de sedimentos na barragem (CARVALHO, 2008). 
Quando construída a barragem e iniciado seu funcionamento, estudos sedimentométricos são necessários para o acompanhamento da evolução do assoreamento do reservatório. A esta fase dos estudos de deposição de sedimentos denomina-se de fase de operação. Nesta etapa, os esforços e vigilância nos estudos dos processos sedimentológicos devem ser permanentes (WANG; HU, 2009). Reservatórios de água por barramentos de rios geralmente influenciam o desenvolvimento da região (ALCÂNTARA et al., 2010), alterando os usos do solo, principalmente na agropecuária, modificando as características do aporte de sedimentos nos corpos d'água (CARVALHO, 2008; THOTHONG et al., 2011).

Nesta fase, levantamentos sistemáticos da topografia do fundo do reservatório são necessários para a determinação da disponibilidade hídrica e constante atualização das curvas cota x área x volume, a fim de se planejar e garantir o melhor aproveitamento da água represada, seja para produção de energia ou para outros usos múltiplos. O conhecimento do volume do reservatório é particularmente importante para a gestão de abastecimento de água na área de influência da represa durante os períodos de seca ou cheia (ALCÂNTARA et al., 2010).

No entanto, a dificuldade em se estudar assoreamento em corpos d'água está na determinação e quantificação do volume de material depositado em seus leitos.

\subsubsection{Método qualitativo}

Os métodos qualitativos de estudo de deposição de sedimentos em reservatórios buscam demonstrar a influência do acúmulo de sedimentos nas atividades que envolvem o uso das represas. Maia e Villela (2010) estudaram a distribuição do assoreamento no reservatório de Promissão, SP em busca de analisar a interferência dos bancos de areia no volume útil do reservatório. O estudo apontou a baixa interferência dos sedimentos no corpo principal da represa, sendo a maior influência observada nos tributários da represa, no qual dois obtiveram $100 \%$ de assoreamento em 30 anos de existência do reservatório.

Kolding e Zwieten (2012) mostraram que as flutuações do nível da água em relação à profundidade de um sistema parecem ter influências significativas nos atributos do ecossistema em geral e na produção biológica de lagos e reservatórios tropicais.

A morfologia dos lagos, bem como a presença de nutrientes, são descritos pelos autores como fatores abióticos que interferem em partes na produção biológica destes 
ambientes. Assim, o assoreamento de reservatórios tem influência direta na variação da população de certos organismos aquáticos.

\subsubsection{Método quantitativo}

\subsection{Avaliação direta}

\subsection{Estudos de Sensoriamento Remoto}

O sensoriamento remoto vem sendo utilizado como ferramenta para determinação do assoreamento em corpos d'água rasos (FENG et al., 2011). A técnica utiliza sofisticados sensores para medir a quantidade de energia liberada por um objeto, ou região à distância, e interpreta as informações captadas usando algoritmos matemáticos e estatísticos. Estes sistemas ópticos podem ser passivos, como fotografias aéreas, ou ativos, como imagens de satélite (JENSEN, 1949).

Imagens de satélite, por exemplo, foram essenciais no trabalho desenvolvido por Alcântara et al. (2010) para determinação da altimetria e características do terreno em estudo. Os autores utilizaram imagens SRTM com dados de altimetria e imagens Ladsat-5 TM para caracterização dos limites e topografia da represa da UHE Itumbiara. Apesar das imagens SRTM fornecerem informações refinadas para a topografia da área, o sensor é incapaz de captar as informações topográficas do interior da represa, abaixo da superfície molhada, limitando a metodologia para a aquisição de dados de profundidade, além de sofrer com a interferência das variações climáticas.

Assim, no intuito de transpor essas barreiras, outra técnica de medição por sensor ativo foi empregada, utilizando o Radar LIDAR. Este sensor proporciona a aquisição de dados de forma rápida para avaliação da sedimentação em reservatórios (PFENNIGBAUER et al., 2011), devido à sua vantagem em transpor a barreira das nuvens, dificuldade enfrentada em outra metodologias por sensoriamento remoto (ALCÂNTARA et al., 2010). A restrição ao seu uso rotineiro está na necessidade de condições ideais de superfície do corpo d'água, como baixa turbidez e águas claras, além do alto custo de execução e faixa estreita captada nas imagens (ALCÂNTARA et al., 2010).

A metodologia do sensoriamento remoto passivo que mede a luz solar refletida, também tem sido utilizada a décadas para obtenção de mapas batimétricos. Esta técnica utiliza a relação empírica entre várias bandas espectrais de águas rasas para derivar mapas 
batimétricos usando algoritmos de rede neural (ALCÂNTARA et al., 2010). A batimetria hidráulica assistida (HAB-2), objeto de estudo de Walther, Marcus e Fonstad (2011), utiliza imagens aéreas para mapear a altimetria de fundo de rios e reservatórios. Apesar da metodologia demonstrar resultados compatíveis com dados coletados por sensores de ecos em solo, o procedimento está sujeita à profundidade máxima de 1,5 metros e a erros nas imagens associados a sombras, corredeiras e obstruções.

No estudo de Alcântara et al. (2010) realizado na represa da Hidrelétrica de Itumbiara no Brasil, os autores desenvolveram uma nova metodologia para estimar a topografia de fundo de reservatórios. A abordagem metodológica foi baseada na integração de derivados de dados topográficos históricos e de satélite para estimar as profundidades dentro da represa. A informação utilizada pelos autores para a determinação geomorfológica do terreno foi a fusão de dados entre as cartas topográficas 1:250.000, anteriores ao enchimento da represa, com curvas de nível espaçadas em 50 metros, e a altimetria do terreno fornecidas com imagens SRTM, resolução 30 metros, com curvas de nível espaçadas em 30 metros. Os limites da interface água/solo foram traçados com base em imagens Landsat-5 TM para o período histórico de menor variação do volume d'água do reservatório. O resultado obtido foi utilizado para representar as feições originais do terreno, anterior ao enchimento da barragem, e para comparação com estudos batimétricos posteriores.

Assim, alguns métodos de sensoriamento remoto foram utilizados no passado para determinar a batimetria em águas rasas, no entanto, todas as técnicas ativas e passivas de detecção por sensoriamento remoto (batimetria por sonar, LIDAR aerotransportado, Radar e fotografia aérea) são de difícil aplicação em águas profundas, maior que 10 metros, e estão restritas a situações de baixa turbidez no corpo d'água. Assim, novas pesquisas devem ser desenvolvidas visando a solução das barreiras encontradas na mensuração por sensoriamento remoto (ALCÂNTARA et al., 2010).

Imagens do sensor MODIS, nova tecnologia presente no projeto ACQUA da NASA, que apresenta alta resolução temporal, permite o monitoramento sistemático das feições em observação, além de avançar nos estudos de detecção de pequenas profundidade em águas turvas. O novo sensor permite determinar a topografia do fundo de águas rasas com elevada turbidez, podendo ser aplicado em massas de águas costeiras e continentais (FENG et al., 2011). 
Legleiter, Kinzel e Overstreet (2011) também avaliaram a aquisição de dados de profundidade por sensoriamento remoto para rios de leito de areia com elevada concentração de material em suspensão e turbidez da água. Porém o uso da associação da espectroscopia de campo com modelos de transferência radiativa mostraram a limitação da profundidade de estudo em 0,5 metros, estando os resultados sujeitos a um grau significativo de incertezas.

\subsection{Estudos de batimetria por sondagem acústica}

A análise da literatura de estudos de assoreamento aponta apenas uma única metodologia para avaliação direta dos efeitos de deposição de sedimento no leito de reservatórios profundos e oceânicos. A metodologia, conhecida como batimetria por sondagem acústica, consiste em determinar a profundidade dos depósitos de sedimento no interior das represas, lagos, lagoas ou oceano, através da mensuração da altura da coluna d'água com sondagem acústica, georreferenciamento dos dados no campo com sistemas de GPS, determinação da altimetria em relação ao nível d'água, e determinação do contorno do reservatório, no caso de ambientes aquáticos continentais.

Comumente utilizado para estudos de dinâmicas de erosão, transporte e deposição de sedimentos nos leitos oceânicos ao redor do mundo (YOSHIKAWA; NEMOTO, 2010; SILVIO et. al., 2010; RATZOV et. al., 2010; SAVINI; CORSELLI, 2010; LASDRAS et. al., 2011; RAMSAY; PYSKLYWEC, 2011), o método por sondagem acústica vem sendo empregado como ferramenta para o mapeamento de fundo de reservatórios e lagos. Com o intuito de calcular e tabelar as variações de áreas e volumes dos diversos níveis da água, a metodologia por sondagem acústica, aplicada em reservatórios de águas continentais, fornece dados quantitativos reais para que gestores disponham de informações mais confiáveis, necessárias ao gerenciamento e regulamentação do uso deste valioso recurso (ALCÂNTARA et al., 2010).

Os resultados obtidos para estudos frequentes por sondagem acústica de um único reservatório ou canal de drenagem, seguindo a mesma metodologia de equipamentos e planejamentos, fornecem a base de dados para comparação da topografia submersa e a determinação da evolução do assoreamento ou erosão do leito do corpo hídrico (CARVALHO, 2008), parâmetros fundamentais na caracterização e compreensão de muitos processos em sistemas aquáticos (ALCÂNTARA et al., 2010). 
Yang et al. (2011) estudaram a evolução da erosão fluvial no rio Yangtze, na China, utilizando a comparação de levantamentos batimétricos por sondagem acústica. A construção de aproximadamente 50.000 barragens e em especial a da UHE Três Gargantas ao longo do rio Yangtze, provocaram a diminuição drástica do volume de sedimento transportado pelo rio. A consequência da retenção dos sedimentos pelas barragens foi o intenso processo erosivo à jusante, fundo e delta do canal demonstrada pela comparação dos resultados da sondagem acústica. As observações feitas em 2007 pelos autores apontam, com estudos batimétricos, o agravamento da erosão em regiões mais profundas enquanto que não houve grandes alterações em áreas rasas, especialmente no delta. No entanto, a conclusão obtida pelos autores é a tendência do aumento dos processos erosivos com o passar dos anos.

Estudos de análise de assoreamento em grandes reservatórios, como os desenvolvidos por Page et al. (2004 apud ORPIN et. al., 2010), Teixeira (2008), Costa (2009), Thothong et al. (2011) e Haregeweyn et al., (2012), utilizaram-se de técnicas batimétricas com sonar acústico para a determinação das cotas topográficas ao fundo dos reservatórios, para posterior quantificação de material sedimentado.

Page et al. (2004 apud ORPIN et al., 2010) estimaram o assoreamento do lago Tutira, Nova Zelândia, na ordem de 63.000 ton/ano, baseados na comparação entre batimetrias históricas por sondagem acústica (1925 e 1963) e análise da densidade do material dos depósitos.

Teixeira (2008) buscou comparar dados batimétricos do início da operação da represa da UHE de Barra Bonita (SP) com dados obtidos no ano de 2005, porém a inconsistência dos dados antigos impossibilitou suas comparações e consequentemente a quantificação do volume assoreado. Costa (2009) comparou dados topobatimétricos do reservatório da UHE de Três Irmãos (SP) adquiridos em 2008 com cartas topográficas anteriores a construção da barragem em 1971, resultando em uma taxa média de assoreamento de $0,4 \%$ ao ano e, portanto, 6,73\% do volume do reservatório assoreado, concluindo que a taxa encontrada está abaixo da média nacional e mundial, de $0,5 \%$ e $1 \%$, respectivamente.

No reservatório de abastecimento de água Mae Thang, localizado ao norte da Tailândia, também foi realizado um estudo para determinar a perda volumétrica por deposição de sedimentos no seu leito. A partir da comparação de modelos digitais de terreno gerados com informações batimétricas por sondagem acústica (1995 - 2006), 
constatou-se que em 12 anos de análise, a capacidade de armazenamento da represa Mae Thang diminuiu 6,6\% devido ao assoreamento. $O$ estudo ainda verificou que a concentração de depósito de sedimento grosseiro em áreas menos profundas foi 3 vezes maior do que no leito profundo do reservatório, onde se encontram sedimentos mais finos. Estas áreas estão localizadas nas margens do reservatório e regiões de afluência de tributários. O processo de assoreamento e distribuição dos sedimentos no interior da represa são atribuídos às erosões na bacia hidrográfica e influência das inundações excepcionais, respectivamente (THOTHONG et al., 2011).

No estudo realizado por Haregeweyn et al. (2012) para o reservatório Angereb, Etiópia, foram utilizadas dois levantamentos batimétricos por sondagem acústica, 2005 e 2007, para a determinação da capacidade de armazenamento da represa nos períodos de 1997 à 2005, 1997 à 2007 e 2005 à 2007, e o acúmulo de sedimento em seu leito. A análise das batimetrias mostrou uma queda na taxa de deposição de sedimentos com o passar dos anos e a eficiência da implementação de técnicas conservacionistas da água e do solo na fase posterior a construção da barragem.

No lago Candia em Turin, norte da Itália, Sambuelli e Bava (2011) inovaram ao experimentar o uso de radar ao invés de sonda acústica na captação de dados de profundidade. Os pesquisadores utilizaram um radar de penetração no solo, conhecido com GPR, simultaneamente com a metodologia consagrada do sonar acústico para comparação dos dados coletados. Os resultados obtidos demonstraram a viabilidade do uso do radar GPR para batimetria de águas rasas $(<10 \mathrm{~m})$ e com baixa condutividade. Este equipamento também tem a capacidade de estimar o tipo de sedimento depositado no fundo do lago, abolindo alguns estudos antes realizados em laboratório, o que o coloca em vantagem em relação ao uso do sonar acústico para as condições estabelecidas.

\subsection{Avaliação indireta}

Como avaliação indireta do processo de assoreamento em reservatórios, Carvalho (2008) formulou uma equação matemática de previsão de deposição de sedimentos, tendo como dados de entrada: valores de deflúvio sólido total médio anual afluente ao reservatório, eficiência de retenção de sedimentos afluente ao reservatório e o peso específico aparente médio dos depósitos. 
$\mathrm{S}=\frac{\mathrm{D}_{\mathrm{st}} \times \mathrm{E}_{\mathrm{r}}}{\mathrm{T}_{\mathrm{gp}}}=\frac{365 \times \mathrm{Q}_{\mathrm{st}} \times \mathrm{E}_{\mathrm{r}}}{\mathrm{T}_{\mathrm{gp}}}$

Equação 1

Onde:

$\mathrm{S}=$ volume de sedimento retido no reservatório, $\mathrm{m}^{3} / \mathrm{ano}$

$\mathrm{D}_{\mathrm{st}}=$ deflúvio sólido total médio anual afluente ao reservatório, t/ano

$\mathrm{E}_{\mathrm{r}}=$ eficiência de retenção de sedimentos afluente ao reservatório, fração

$\gamma_{\mathrm{ap}}=$ peso específico aparente médio dos depósitos, $\mathrm{t} / \mathrm{m}^{3}$

$\mathrm{Q}_{\mathrm{st}}=$ descarga sólida total média afluente ao reservatório, $\mathrm{t} / \mathrm{dia}$

No entanto, a avaliação do assoreamento por meio da Equação 1 deve ser revista constantemente. As alterações intrínsecas de uso e ocupação do solo decorrentes da implementação de uma represa, alteram ao longo do tempo as condições de transporte de sedimentos, $\mathrm{Q}_{\mathrm{st}}$ e $\mathrm{D}_{\mathrm{st}}$, devido ao aumento dos processos erosivos na bacia, a eficiência de retenção do reservatório, $\mathrm{E}_{\mathrm{r}}$, com o aumento dos depósitos em seu interior, e o peso específico aparente médio, $\gamma_{\mathrm{ap}}$, a medida que os depósitos se compactam devido ao peso da coluna de água. A constância da análise, neste caso, acaba por depender da disponibilidade e consistência das informações hidrosedimentológicas registradas na bacia hidrográfica, ficando o gestor dependente da coleta diária de informações.

A importância de se avaliar o transporte de sedimentos para a caracterização da bacia hidrográfica foi relatada por Fill e Santos (2001), visando à quantificação de impactos do manejo do terreno e alterações antrópicas e estimativa do assoreamento em reservatórios, lagos e estuários. Para estes estudos, geralmente é necessário dispor de uma série temporal longa e contínua da descarga sólida que tradicionalmente é determinada através da chamada curva-chave de sedimentos, obtida a partir de medidas de vazão líquida e da determinação simultânea da concentração de sedimentos em suspensão, arrastados ao longo do fundo e transportados por saltação ao longo do leito (VESTANA et al., 2007).

Wang, Yan e Li (2012), por exemplo, analisaram a variação histórica do sedimento em suspensão em 4 postos sedimentométricos no rio Amarelo, China, no período de 1952 a 2009. Com os registros históricos de sedimentos em suspensão foi possível demonstrar uma drástica variação no período de estudo. A construção de reservatórios ao longo do curso d'água, como no caso do rio Amarelo, favorece a deposição do sedimento em suspensão, no entanto, durante o período estudado, foi 
observado a dinâmica de deposição dos sedimentos nos reservatórios, seguida por um período em 1960-1985 de erosão do leito e, novamente, seguido por um período de deposição. O estudo ainda demonstrou que a partir de 1990 uma maior concentração de material em suspensão foi observado a jusante dos postos de monitoramento. A constatação foi associada, pelos autores, ao preenchimento do volume morto dos reservatórios pelo material depositado, e só foi possível com o registro histórico fluviométrico e sedimentométrico nas represas do rio Amarelo.

Devido à dificuldade de aquisição de dados e custos envolvidos referentes à sedimentação nos recursos hídricos brasileiros, Loureiro (2008) definiu as necessidades relativas à precisão, facilidade, custo e frequência de aquisição dos dados referentes ao aporte de sedimentos em rios, baseado na identificação de tecnologias atuais e nas tecnologias promissoras que estarão disponíveis em curto prazo, demonstrando as diversas possibilidades para o registro destas informações.

Por outro lado, Fill e Santos (2001) contestaram a tradicional aquisição de dados de material transportado em suspensão e avaliaram a concentração destes sólidos a partir de medidas de transparência pelo disco de Sechi, concluindo a viabilidade técnica e econômica da nova metodologia, conduzindo a resultados melhores que a curva-chave de sedimentos.

O conhecimento e a coleta de dados referentes ao transporte de sedimentos são de fundamental importância para estudos na bacia, para projetos de obras hidráulicas, estudos ambientais e usos dos recursos hídricos. No entanto, a falta de dados históricos que caracterizem as condições do aporte de sedimentos nos corpos d'água, dificulta a aplicação de modelos de sedimentação, resultando em projetos de barragens super estimados ou inadequados (HAREGEWEYN et al., 2012).

Assim, para a validade e realidade dos valores finais de assoreamento, a aplicação da equação descrita depende de uma rede sedimentométrica de monitoramento dos recursos hídricos, com dados diários que representem fielmente as alterações hidrossedimentológicas sofridas pela bacia hidrográfica.

Para efeito de cálculo da equação anterior, Brown $\left(1943^{19}\right.$ apud CARVALHO, 2008) estabeleceu a eficiência de retenção de sedimentos em reservatórios, em função da

\footnotetext{
${ }^{19}$ BROWN, C. B. Discussion of sedimentation in reservoir by B. J. Witzig. Procedures American Society of Civil Engineers, v. 69, no. 6, p. 793 - 815, p. 1493 - 1499. 1943.
} 
razão entre a capacidade do reservatório pela área da bacia hidrográfica, com base em observações e dados de alguns reservatórios.

$E_{r}=100\left[1-\frac{1}{1+4,76 \times 10^{-5} \times \frac{V_{r s h}}{A_{b h}}}\right]$

Equação 2

Onde:

$\mathrm{E}_{\mathrm{r}}=$ eficiência de retenção de sedimentos, \%

$\mathrm{V}_{\text {res }}=$ capacidade do reservatório, $\mathrm{m}^{3}$

$\mathrm{A}_{\mathrm{bh}}=$ área da bacia hidrográfica, $\mathrm{m}^{2}$

No entanto a equação determinada por Brown não considera informações em função da localização do reservatório. Em regiões secas as condições de depósito são mais favoráveis que em regiões úmidas (CARVALHO, 2008).

Outra equação para determinação da eficiência de retenção de sedimentos em reservatórios foi estabelecida por Heinemann (1981 ${ }^{20}$ apud CARVALHO, 2008), que considerou em seus cálculos a relação da razão da capacidade do reservatório pelo volume médio afluente anual, tendo por base valores observados em pequenos reservatórios.

$E_{r}=-22-\frac{119,6 \times \frac{V_{r g s}}{V_{a f l}}}{0,012-1.02 \times \frac{V_{Y E S}}{V_{a f l}}}$

Onde:

$\mathrm{E}_{\mathrm{r}}=$ eficiência de retenção de sedimentos, \%

$\mathrm{V}_{\text {res }}=$ capacidade do reservatório, $\mathrm{m}^{3}$

$\mathrm{V}_{\mathrm{afl}}=$ volume médio afluente anual, $\mathrm{m}^{3}$

Carvalho (2008) aponta que estas equações são menos conhecidas e que, no Brasil, as mais comumente utilizadas são a de Gunnar Brune e o de Churchill.

O método de Brune (1953 ${ }^{21}$ apud CARVALHO, 2008) leva em consideração em seus resultados, além da capacidade de afluência estabelecida por Heinemann (1981 apud

\footnotetext{
${ }^{20}$ HEINEMANN, H. G. A new sediment trap efficiency curve for small reservoir. Water Resources Bulletin, Ed. 17, p. 825 - 830, 1981.

${ }^{21}$ BRUNE, G. Trap efficiency of reservoirs. Trans. of Am. Geophysical Union, 34(3), p. 407 - 418, 1953.
} 
CARVALHO, 2008), razão da capacidade do reservatório pelo volume médio afluente anual, os valores referentes a granulometria do material depositado em vários reservatórios dos EUA. Com base nestes fatores, o autor estabeleceu uma curva média em gráfico logarítmico para a determinação da eficiência de retenção (Figura 1).

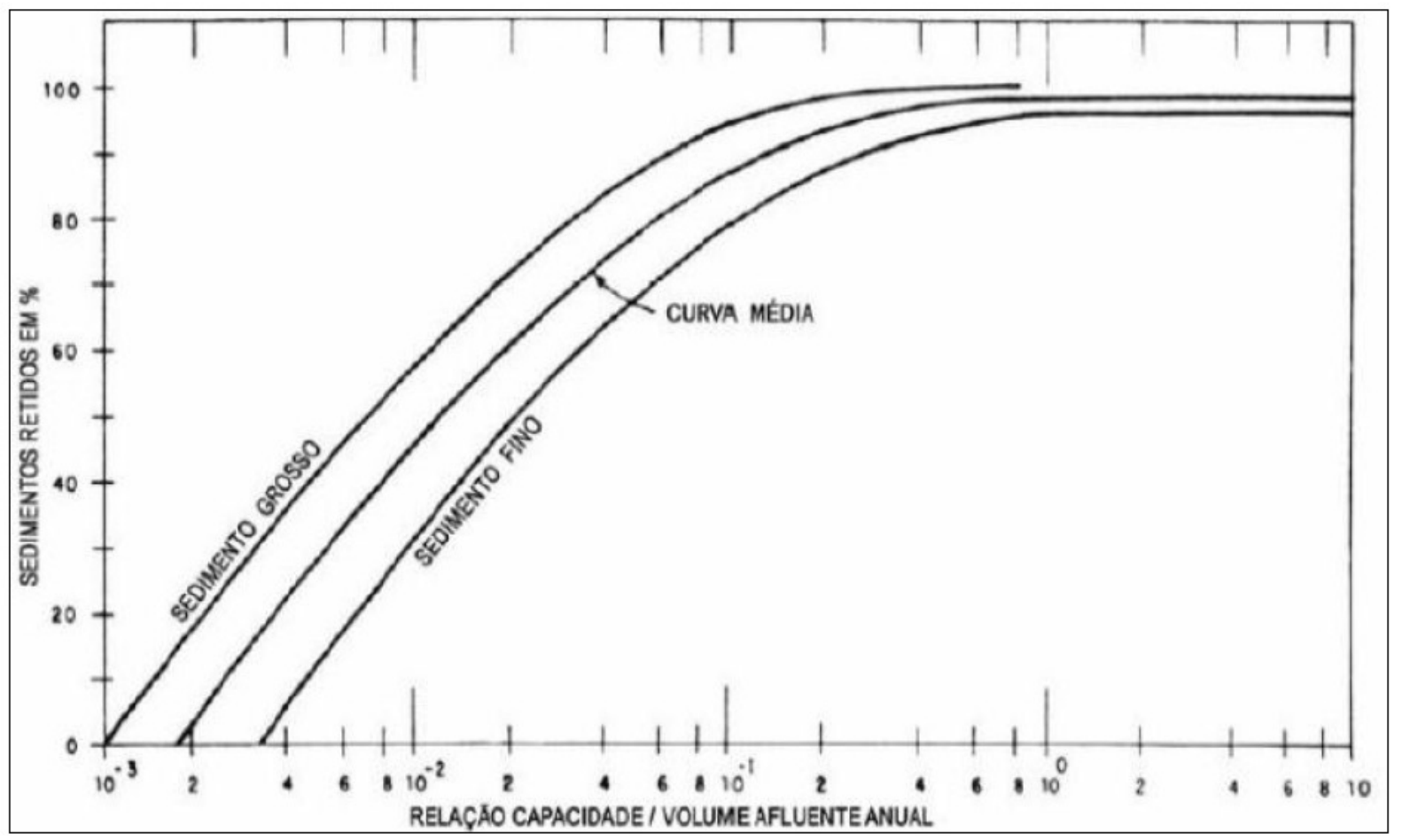

Figura 1. Gráfico de eficiência de retenção de sedimento de Brune (1953) Fonte: Carvalho (2008)

Já a curva de retenção estabelecida por Churchill (sem data) e apresentada por Strand (1974 ${ }^{22}$ apud CARVALHO, 2008) e Vanoni (1977²3 apud CARVALHO, 2008) tem por base os valores de índice de sedimentação, que corresponde a razão entre o período de retenção pela velocidade média no reservatório.

$I S=\frac{V_{r s s}^{2}}{Q^{2} \times L}$

Equação 4

Onde:

IS = índice de sedimentação do reservatório, $\mathrm{s}^{2} \cdot \mathrm{ft}^{-1}$

$\mathrm{V}_{\text {res }}=$ volume do reservatório no nível médio de operação, $\mathrm{ft}^{3}$

$\mathrm{Q}=$ vazão afluente média diária durante o período de estudo, $\mathrm{ft}^{3} . \mathrm{s}^{-1}$

${ }^{22}$ STRAND, R. I. Sedimentation - Design of Small Dams. Washington, D.C.: USBR - United States Bureau of Reclamation. 1974.

${ }^{23}$ VANONI, V. A. Sedimentation Engineering: manuals and reports on engineering pratice. New York: ASCE, n 54, 1977. 745 p. 
$\mathrm{L}=$ comprimento do reservatório, $\mathrm{ft}$

Assim, para o cálculo da eficiência de retenção temos a seguinte expressão:

$E_{r}=100-\left[1600 \times(I S \times g)^{-0,2}-12\right]$

Equação 5

Onde:

$\mathrm{E}_{\mathrm{r}}=$ eficiência de retenção de sedimentos, \%

IS = índice de sedimentação do reservatório, $\mathrm{s}^{2} \cdot \mathrm{ft}^{-1}$

$\mathrm{g}=$ aceleração da gravidade, $\mathrm{ft} . \mathrm{s}^{-2}$

Outros métodos empíricos e analíticos são utilizados para a previsão de assoreamento em reservatórios. Em destaque para os mais utilizadas no Brasil estão os métodos empíricos "Método empírico de redução de área", desenvolvido por Borland e Miller (1958 ${ }^{24}$ apud CARVALHO, 2008) e o " Método de área incremental", desenvolvido por Borland (1970 25 apud CARVALHO, 2008).

A Tabela 2 relaciona os métodos mais conhecidos, descritos por Carvalho (2008).

Tabela 2. Métodos de avaliação do processo de assoreamento em reservatórios.

\begin{tabular}{cc}
\hline MÉTODOS EMPÍRICOS & MÉTODOS ANALÍTICOS \\
\hline Borland \& Miller, 1958 & White \& Bettes, 1984 \\
Menné \& Kriel, 1959 & Pitt \& Thompson, 1984 \\
Borland, 1970 & SEDRES de Croley II, 1978 \\
& Lopez, 1978 \\
& Ana Maria Alvim, 1989 (método brasileiro) \\
& Rogério Campos, 2001 (método brasileiro) \\
& HEC-6, 1960 \\
\hline
\end{tabular}

Fonte: Carvalho (2008)

Lu et al. (2010), por exemplo, utilizaram um modelo 2D para fluxo de água na previsão de mudança espaço-temporal da sedimentação na UHE Três Gargantas, China. O estudo revelou que na modelação das características de sedimentação, a construção de reservatórios a montante do rio Yangtze e rio Jialing, principais rios afluentes, reduziriam o aporte de sedimentos ao reservatório da UHE Três Gargantas consideravelmente. A

\footnotetext{
${ }^{24}$ BORLAND, W. M., MILLER, C. R. Distribution of Sediment in Large Reservoirs. Journal of the Hydrological Division, ASCE. 1958. v. 84.

${ }^{25}$ BORLAND, W. M. Reservoir Sedimentation in River Mechanics. Fort Collins: Water Resources Publications. 1970.
} 
quantidade de sedimento liberada pelas barragens nos dois rios afluentes a UHE Três Gargantas seria de $17,4 \%$ e $10,3 \%$, respectivamente, do valor total modelado para as condições sem a presença das barragens.

Maia e Villela (2009) apresentaram um estudo do assoreamento de reservatório baseados no estudo de caso da UHE de Promissão, localizado no médio Tietê, entre o período de 1975 e 2005. Utilizaram-se da topobatimetria, de cartas topográficas anteriores ao enchimento da barragem, e do módulo de "análise de volume" do modelo RESSASS para análise da variação do volume do reservatório neste período. Os valores de assoreamento encontrados pelos autores atingiram 3,73\% do volume total do reservatório.

A equação universal da perda de solos também pode ser utilizada para a previsão indireta do assoreamento de reservatórios, desde que calibrada e validada para cada nova área em que for empregada. Em estudo realizado no reservatório Vrchlice, República Tcheca, Krasa et al. (2005) demonstraram, a partir da comparação com resultados de levantamento batimétrico, a viabilidade do uso da EUPS no país para a quantificação do depósito de sedimentos no interior de represas. A batimetria demonstrou um acúmulo de sedimentos no reservatório da ordem de $120.000 \mathrm{~m}^{3}$ a $140.000 \mathrm{~m}^{3}$ enquanto que a EUPS quantificou o solo perdido por erosão em aproximadamente $111.000 \mathrm{~m}^{3}$. Para o caso da Republica Tcheca, o método se mostrou eficiente mas deve ser aplicado em outras regiões para comparação e validação do método. 


\section{MATERIAIS E MÉTODOS}

\subsection{Descrição da área de estudo}

\subsubsection{Localização e vias de acesso}

A área do presente estudo está compreendida totalmente dentro do município de Santo Antônio do Aracanguá, região que fica localizada na macrorregião de Araçatuba no estado de São Paulo. É limitada pelas coordenadas UTM 524000m e 546000m E; e $7690000 \mathrm{~m}$ e $7714000 \mathrm{~m} \mathrm{~S}$, na zona 22S, datum horizontal WGS84. Apresenta uma área e um perímetro reais aproximados de, respectivamente, $208,2 \mathrm{~km}^{2}$ e $74 \mathrm{~km}$.

A bacia hidrográfica em estudo corresponde a sub-bacia do Ribeirão das Cruzes, pertencente à Bacia do Rio Tietê, na Unidade Hidrográfica de Gerenciamento de Recursos Hídricos - UGRHI - 19, conhecida como Baixo Tietê. O canal principal está disposto preferencialmente no sentido NE-SW, e assim como suas nascentes está localizado nos terrenos do Planalto Ocidental (Figura 2).

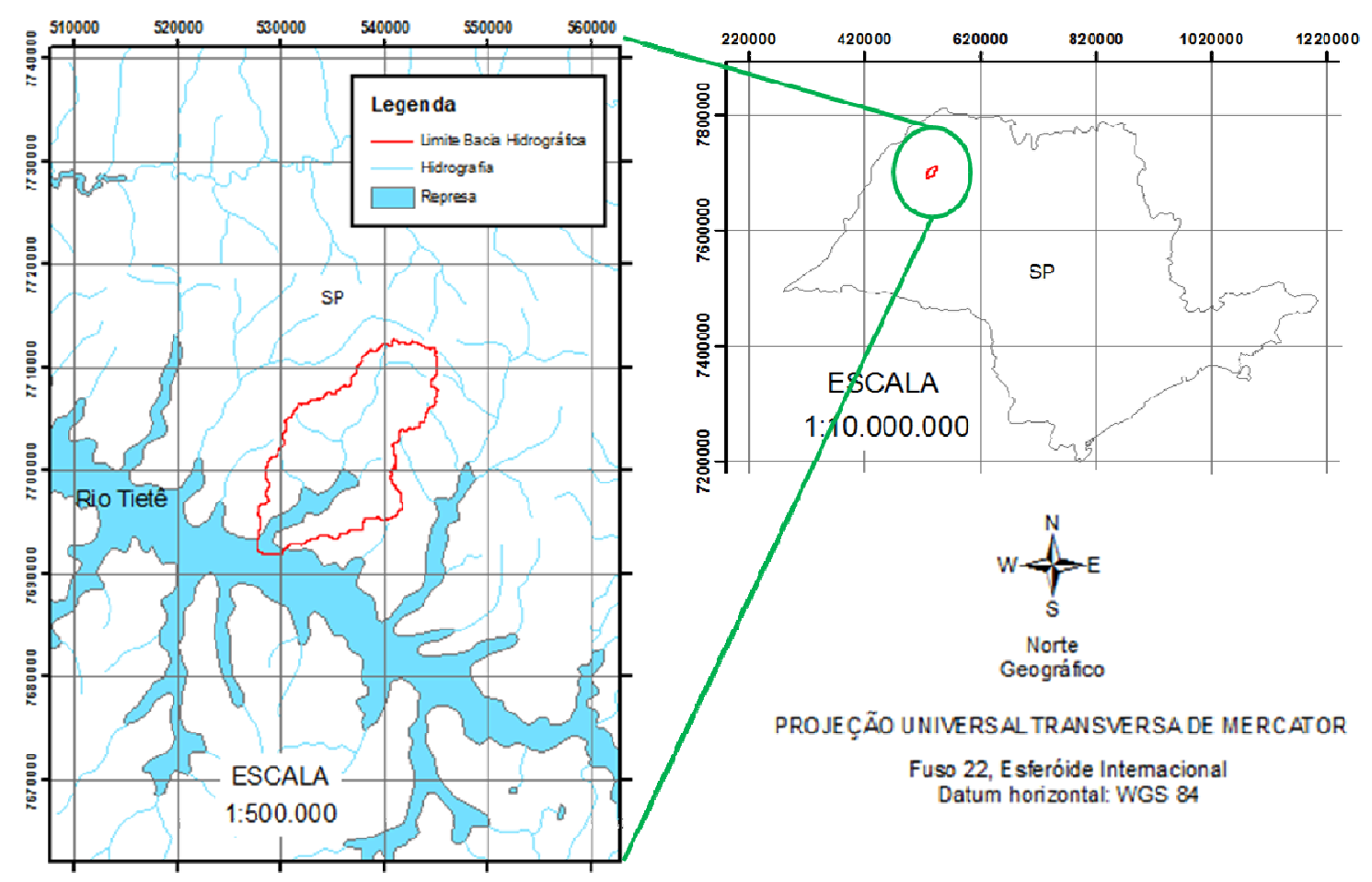

Figura 2. Localização da Bacia Hidrográfica do Ribeirão das Cruzes no Estado de São Paulo. Fonte: Adaptado de Mapas Interativos IBGE

Como principal via de acesso à área de estudo, temos a estrada vicinal que interliga os municípios de Santo Antônio do Aracanguá - SP, com acesso a rodovia SP - 463 (Elyeser 
Montenegro Magalhães) e Auriflama - SP, com acesso a rodovia SP - 310 (Washington Luiz).

Os municípios limítrofes à Santo Antônio do Aracanguá, a partir do norte em sentido horário, são: Guzolândia, Auriflama, General Salgado, Nova Castilho, Nova Luzitânia, Lourdes, Buritama, Araçatuba, Pereira Barreto e Sud Mennucci.

\subsubsection{Clima}

O clima da região de Santo Antônio do Aracanguá, de acordo com a classificação de Köppen (1936), está indicado como CWa (clima Subtropical Úmido), com inverno seco e verão quente e úmido. A região encontra-se sob a influência das massas de ar Tropical Continental e Polar Antártica, caracterizando o típico regime pluviométrico tropical, com um período chuvoso, entre os meses de outubro e março, e um período de estiagem de abril a setembro. A pluviosidade anual média, entre os anos de 1970 e 2004, foi de $1200 \mathrm{~mm}$ segundo o Sistema Integrado de Gerenciamento de Recursos Hídricos de São Paulo para valores não consistidos do posto pluviométrico de prefixo B7-045 no município de Auriflama. O mês de janeiro se caracteriza pela maior média mensal, aproximadamente $225 \mathrm{~mm}$, em oposição a média mensal histórica de julho de aproximadamente $20 \mathrm{~mm}$, mês de menor pluviosidade.

A temperatura anual varia de $14^{\circ} \mathrm{C}$ a $22^{\circ} \mathrm{C}$ no período de inverno e de $24^{\circ} \mathrm{C}$ a $30^{\circ} \mathrm{C}$ no período de verão segundo o CETEC (2008).

\subsubsection{Uso e ocupação}

No oeste do estado de São Paulo o uso e ocupação do solo se deram pela expansão agrícola no início do século XX com a cafeicultura ao longo das ferrovias. Com a crise do mercado internacional e a consequente queda nos preços do café, outros insumos agrícolas passaram a prevalecer na região, predominando atualmente a pecuária bovina de corte extensiva.

A área da bacia hidrográfica em estudo não apresenta ocupação por manchas urbanas ou atividades do setor industrial, sendo seu espaço territorial totalmente destinado à pecuária e produção agrícola em larga escala. Segundo os dados fornecidos pela CETEC (2008) para uso e ocupação do solo na região, $78,3 \%$ da área em planta da bacia hidrográfica está ocupada com pastagens para a pecuária bovina, $11,4 \%$ com o cultivo de cana de açúcar, $6,1 \%$ com o 
espelho d'água formado pela represa, restando apenas $4,2 \%$ da área em planta ocupada por glebas de matas remanescentes e matas galerias (Figura 3 e APÊNDICE A).

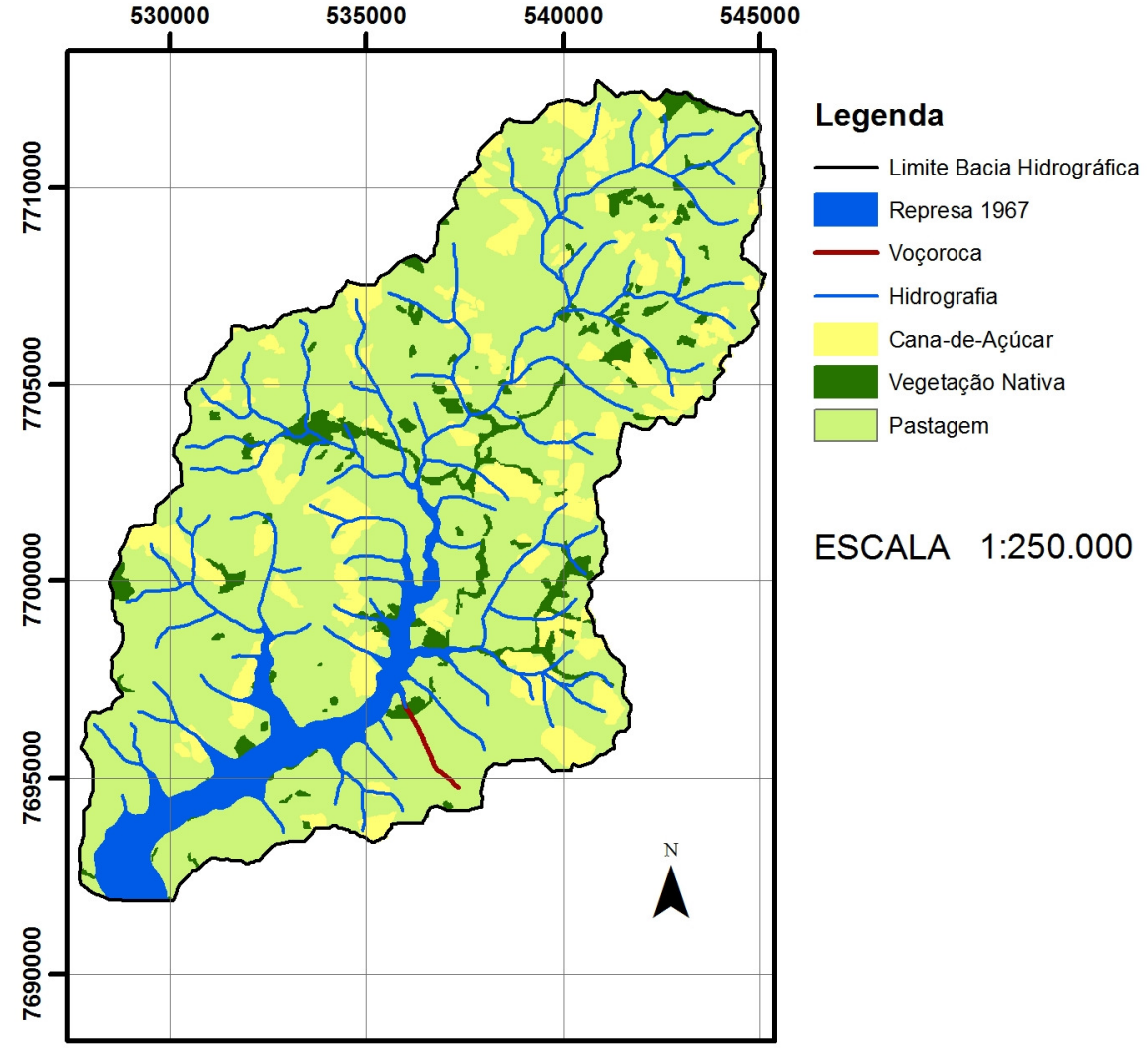

Figura 3. Uso e ocupação do solo na bacia hidrográfica do Ribeirãos das Cruzes. Fonte: Adaptada de CETEC (2008).

Nas visitas em campo e na análise de imagem de satélite fornecida pelo Google Maps para o ano de 2001 (Figura 4), não foram identificadas significativas porções ou glebas de vegetação natural preservadas na área da Bacia Hidrográfica do Ribeirão das Cruzes. O próprio Plano de Bacia do Baixo Tietê aponta a deficiência na cobertura vegetal nativa, que totaliza apenas $5 \%$ de toda a área da bacia hidrográfica do Baixo Tietê. 


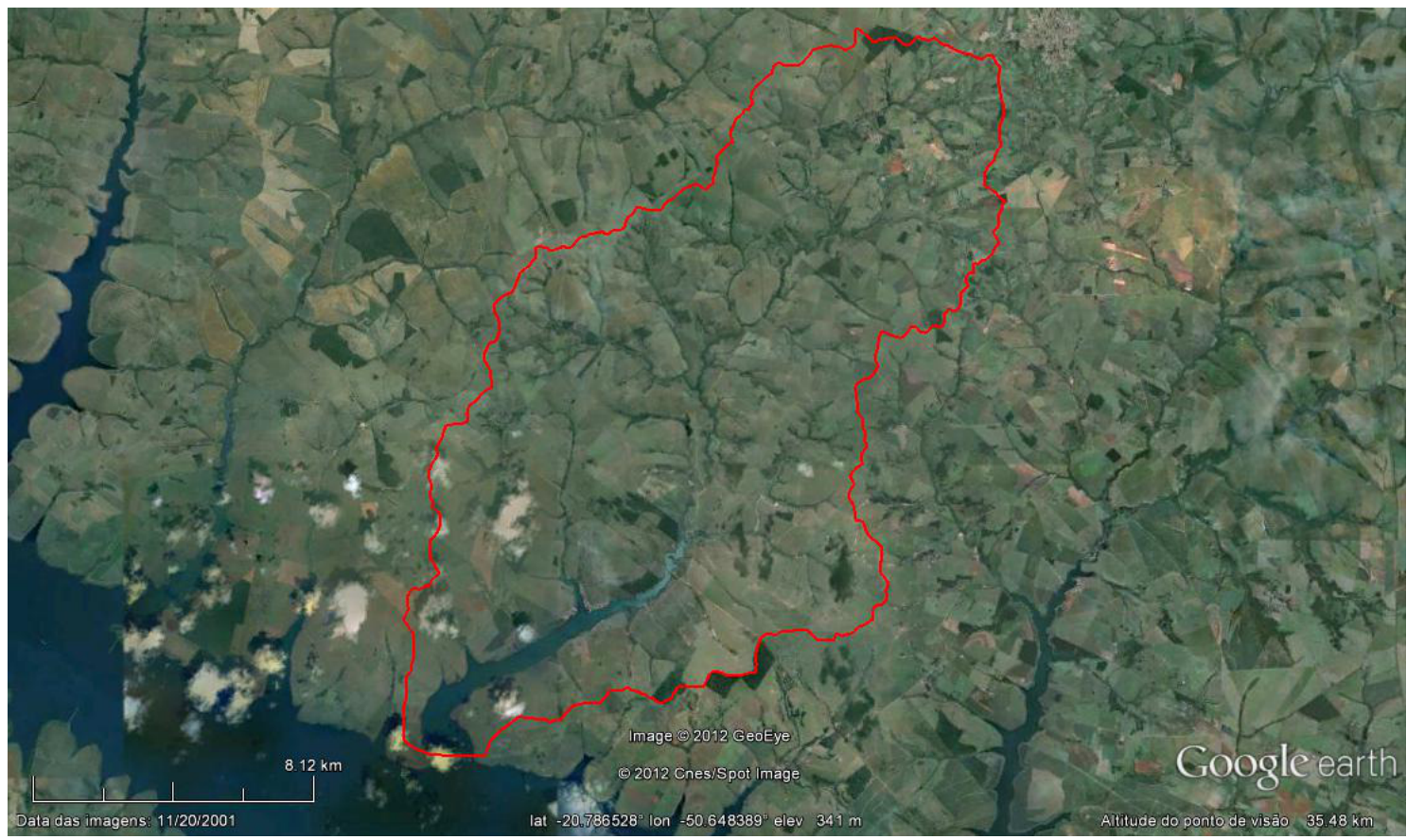

Figura 4. Imagem do local (20/11/2001) com perímetro da bacia hidrográfica do Riberão das Cruzes.

Fonte: Google Earth (Centro da Imagem: 20 $46^{\prime} 47^{\prime \prime} S 5^{\circ} 38^{\prime} 56^{\prime \prime} O$ - Acesso em: 07 mar. 2012)

Praticamente toda a área de preservação permanente - APP no entorno da represa não apresenta a devida proteção com vegetação estabelecida pela lei 4771/65, Código Florestal, sendo esta ocupada totalmente por pastagens de Brachiaria sp (Figura 5). Apenas alguns córregos na cabeceira da bacia apresentam vestígios de vegetação em suas margens e nascentes.

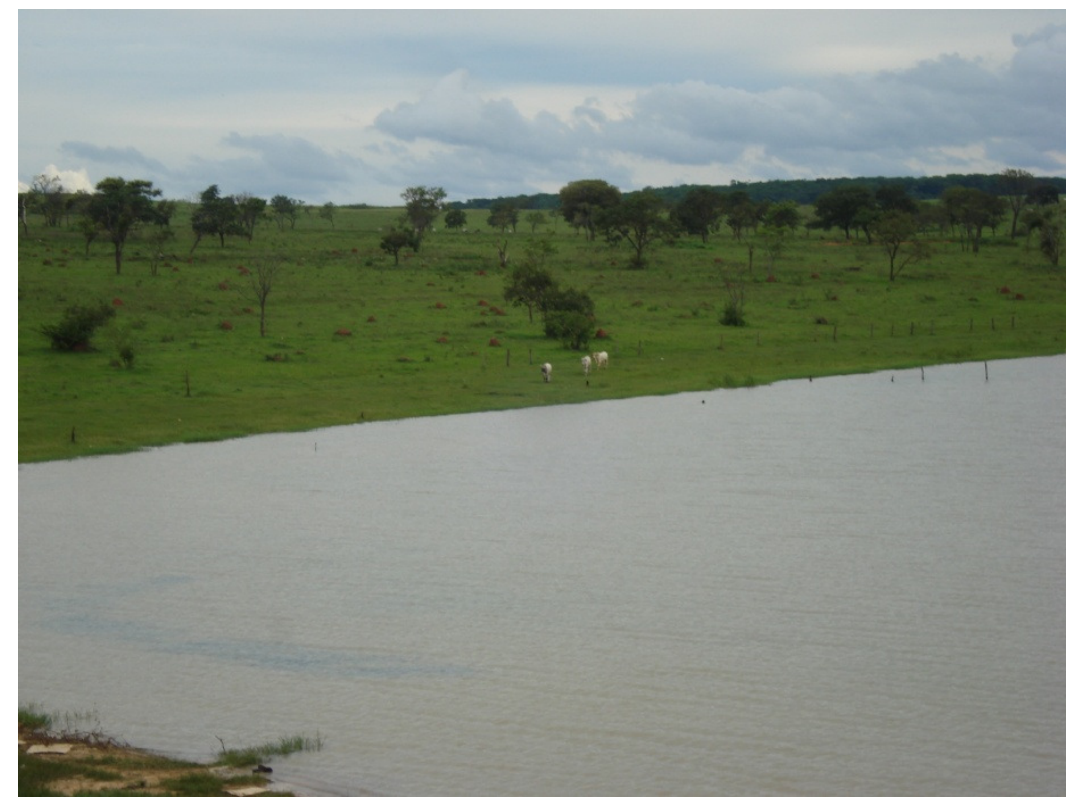

Figura 5. Ocupação das margens do Ribeirão das Cruzes por pastagens. 
Cabe neste ponto ressaltar a pressão que a área vem sofrendo com a expansão do plantio da cana de açúcar. No período decorrido durante as duas visitas realizadas a campo, janeiro e setembro de 2011, o uso da área da bacia hidrográfica da erosão em estudo foi alterado, por completo, de pastagem com Brachiaria sp (Figura 6) para área de canavicultura (Figura 7). O Plano de Bacia ainda aponta o crescimento de $155,5 \%$ da canavicultura no município de Santo Antônio do Aracanguá - SP no período de 1995 a 2008 em decorrência da instalação e/ou potencialização de diversas usinas de açúcar e álcool na região.

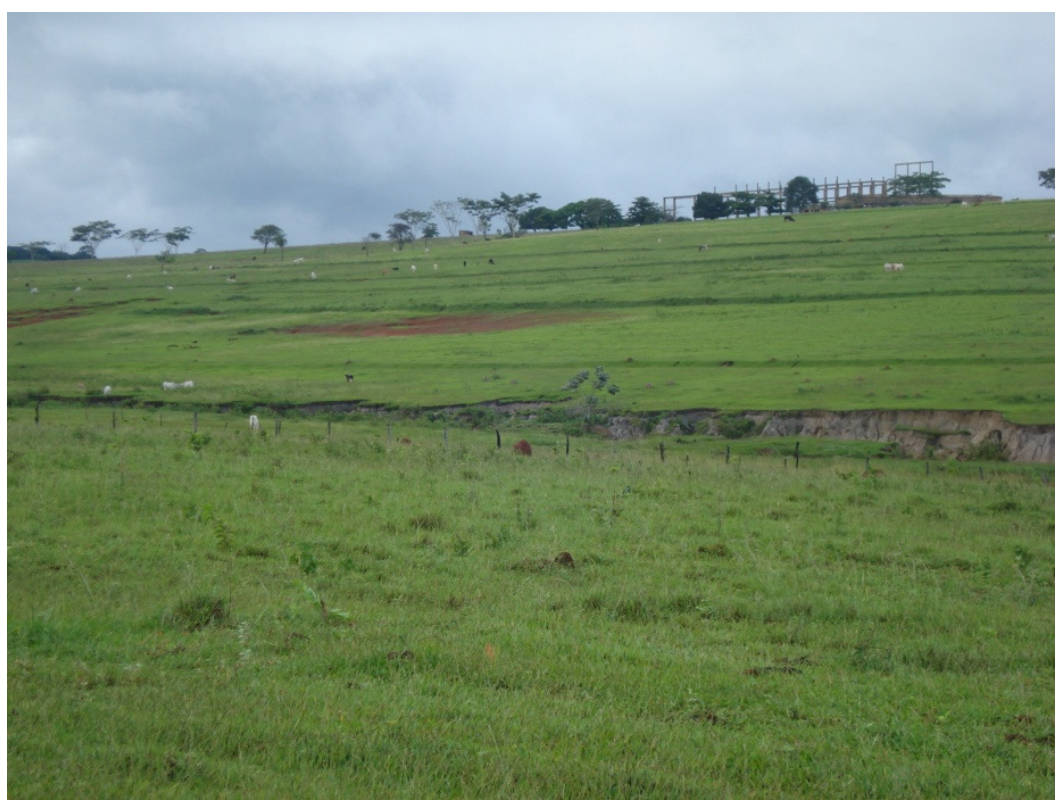

Figura 6. Ocupação do entorno da voçoroca por pastagem (janeiro de 2011).

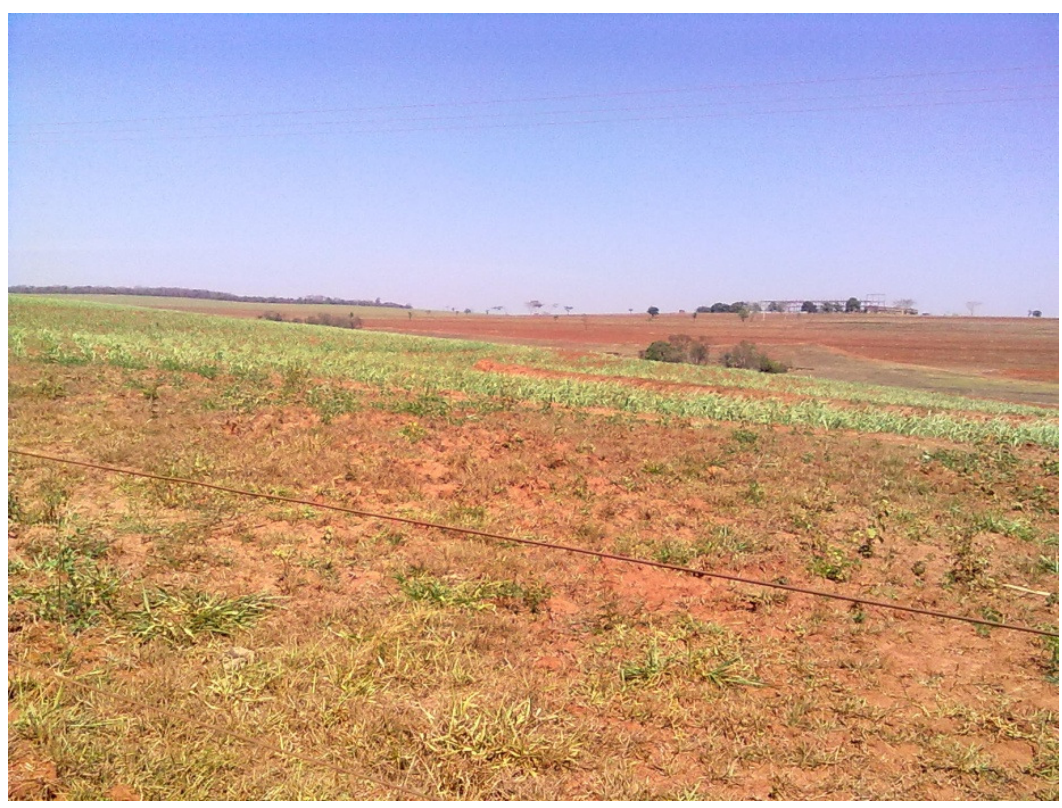

Figura 7. Ocupação do entorno da voçoroca por cana-de-açúcar (setembro de 2011). 


\subsubsection{Geologia, pedologia e geomorfologia}

A área da Bacia Hidrográfica do Ribeirão das Cruzes compreende duas unidades litológicas, classificadas pela CPRM em: Unidade Araçatuba (K2ar) e Unidade Vale do Rio do Peixe (K2vp). A idade relativa à formação das rochas em ambas as unidades compreende de 65 a 100 milhões de anos, que na escala dos tempos geológicos estão classificadas da seguinte forma: EON - Fanerozóico; ERA - Mesozóico; PERÍODO - Cretáceo; EPOCA Superior (Figura 8 A).
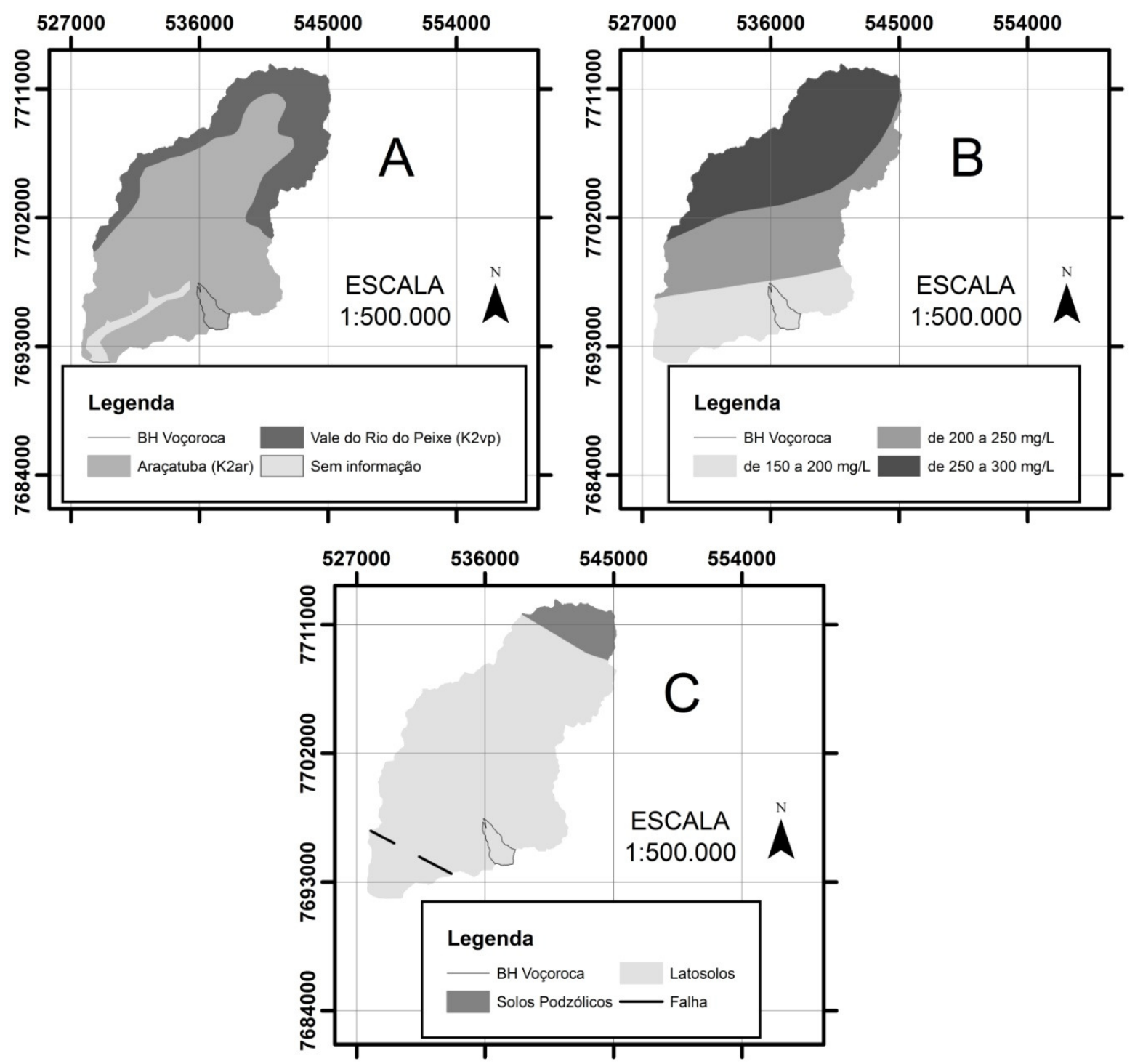

Figura 8. Caracterização da bacia hidrográfica do Ribeirão das Cruzes. A: Unidades litológicas. B: Teor de salinidade. C: Tipos de solo. Datum: Córrego Alegre.

Fonte: Adaptado de Mapas Interativos IBGE

A hidrogeologia da área da bacia está inserida nas rochas sedimentares do grupo Bauru, aquífero freático com recarga por precipitação pluvial. Apresenta teores de salinidade 
variando de $150 \mathrm{mg} / \mathrm{L}$ em sua foz à $300 \mathrm{mg} / \mathrm{L}$ na região de nascentes ao norte, próximo a cidade de Auriflama, SP, sendo o teor salino para a área da erosão em estudo variando de 150 à $200 \mathrm{mg} / \mathrm{L}$. O tipo químico da hidrogeologia para toda a bacia está classificado em bicarbonatada cálcica (Figura $8 \mathrm{~B}$ ).

O Latosolo vermelho-amarelo está presente em praticamente toda a área de estudo. Apenas uma pequena parcela no extremo norte da bacia hidrográfica apresenta solos do tipo Podzólicos (Figura 8 C).

A região apresenta uma descontinuidade classificada como falha indiscriminada ao sul da bacia hidrográfica (Figura $8 \mathrm{C}$ ).

Por estar inserida na província geomorfológica do planalto ocidental, colinas amplas e suaves são a forma de relevo predominante, caracterizadas por variações de declividades entre 3 a 10 graus e topográfica de 20 a 50 metros.

\subsubsection{Erosão}

O prevalecimento de critérios de crescimento de ordem econômica para a ocupação e desenvolvimento do Oeste do estado de São Paulo, favoreceu um desmatamento desordenado na região que, em conjunto com as condições naturais do solo e clima local, culminaram em alterações nítidas do meio ambiente, principalmente no que tange os processos da sedimentação (FUJIHARA, 2002).

No Plano de Bacia do Baixo Tietê, a CETEC (2008) classificou a área da grande bacia hidrográfica do Baixo Tietê em três categorias de susceptibilidade a ocorrência de erosão laminar: baixa, média e alta susceptibilidade, correlacionando os diferentes graus de pontencialidade "natural" e "antrópica", de acordo com os dados constantes no relatório de Bases de Dados Geoambientais do Estado de São Paulo.

Para os limites da bacia hidrográfica do Ribeirão das Cruzes os riscos associados aos processos erosivos estão classificados em alta e média susceptibilidade à atuação de erosão laminar, sendo frequente o desenvolvimento de sulcos, ravinas e voçorocas CETEC (2008) (Figura 9). Na região da bacia hidrográfica em que está inserida a erosão do presente estudo (Figura 10), as condições de desenvolvimento de processos erosivos foi classificada como média susceptibilidade. 


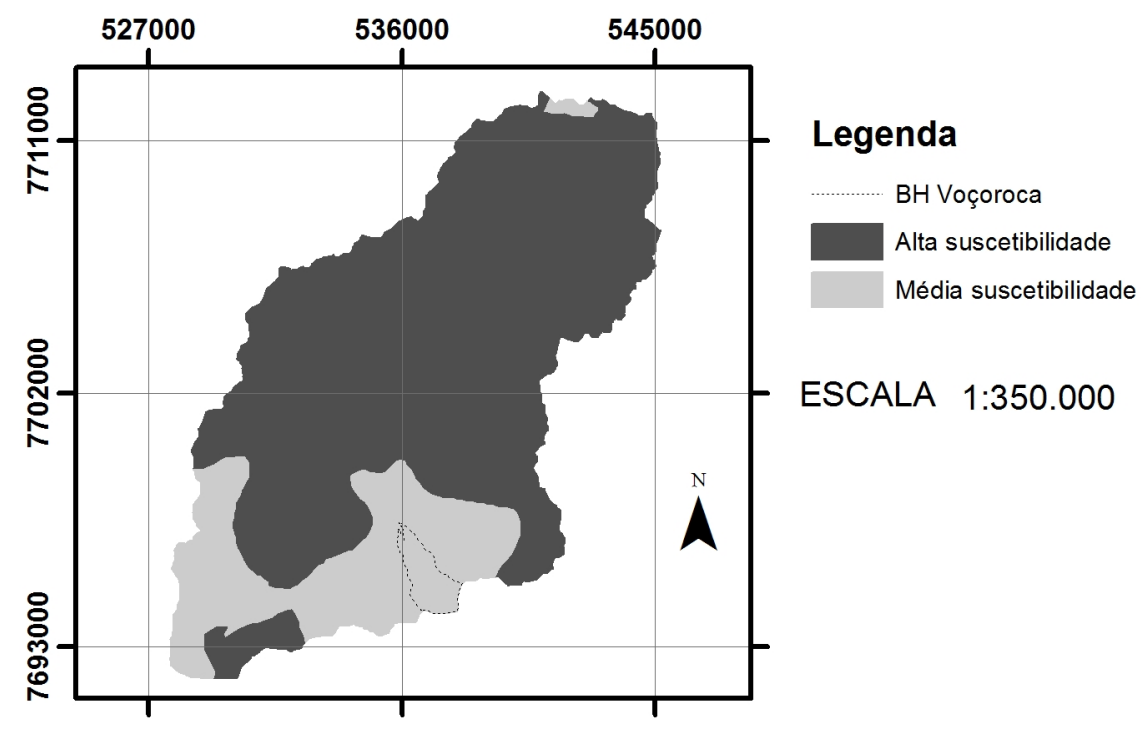

Figura 9. Susceptibilidade à erosão da bacia hidrográfica do Ribeirão das Cruzes. Datum: Córrego Alegre. Fonte: Adaptado de CETEC (2008).

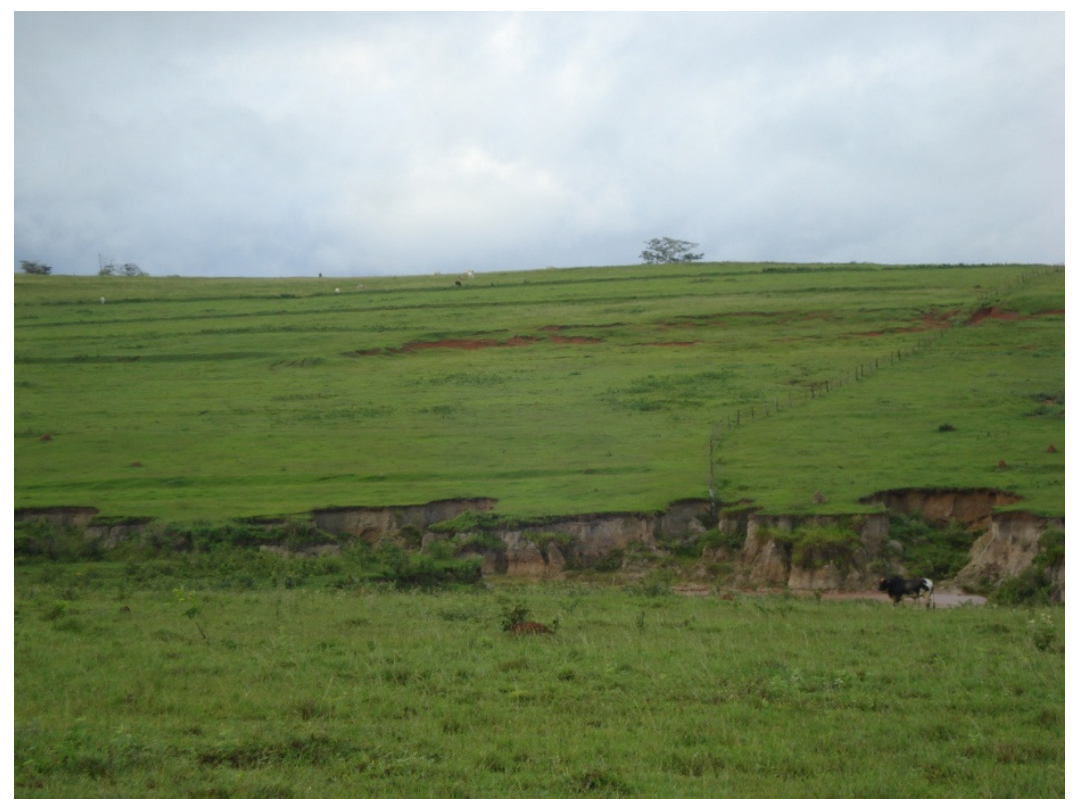

Figura 10. Área de estudo: trecho da voçoroca.

\subsection{Processo de assoreamento relacionado a erosão linear}

Para o conhecimento da contribuição da erosão linear no processo de assoreamento do ribeirão das Cruzes se faz necessário a comparação entre o volume de material perdido pela erosão, o volume de material depositado no leito do ribeirão e a capacidade de deposição do sedimento em suspensão em toda a extensão do represamento em estudo, de modo a caracterizar o balanço de massa do sedimento neste ambiente. 
No entanto foi utilizada apenas a mensuração in situ, com equipamentos precisos para aquisição de dados que caracterizem as feições dos terrenos, e as pesquisas bibliográficas a mapas temáticos e imagens de satélite da região, de forma a contribuir com dados reais e históricos nos trabalhos computacionais de modelação de terreno. Para a capacidade de retenção dos sedimentos dentro do reservatório não foram realizados estudos mais profundos, apenas adotando a retenção de $100 \%$ do material que adentra ao reservatório.

\subsubsection{Análise da existência da voçoroca}

Para a determinação da época de surgimento da voçoroca foram utilizadas imagens de sensoriamento remoto disponibilizadas pelo Instituto Nacional de Pesquisas Espaciais - INPE em seu portal web site.

As imagens selecionadas para o presente estudo foram geradas pelo sensor TM do satélite Ladsat 5, por apresentar uma boa resolução espacial para análise visual (30 metros) e pela disponibilidade de imagens históricas do local que permite a comparação das modificações ocorridas.

A análise do desencadeamento do processo erosivo foi realisada visualmente, utilizando a composição de bandas 3 vermelho, 2 verde e 1 azul, que representam as imagens nas cores reais segundo a capacidade visual humana, para determinar a transição de imagens em que houve, de fato, o surgimento da voçoroca.

\subsubsection{Quantificação do volume do solo erodido na voçoroca}

\subsubsection{Levantamento topográfico}

A modelação digital do terreno (MDT), a partir da aquisição de dados por levantamento topográfico, tem o intuito de permitir uma análise ambiental mais prática e confiável do ponto de vista da engenharia, por representar, de forma mais fiel possível em escritório, as condições reais do terreno, permitindo ao gestor a previsão de suas diversas respostas a condições de alteração do meio ambiente.

As interações entre diversos MDT's, permitidas através de relações booleanas de sistemas de informações geográficas (SIG), fornecem dados relevantes para estudos de engenharia como, por exemplo, perímetros, áreas e volumes, que anteriormente aos SIG's eram de difícil aquisição. 
O levantamento topográfico dos perfis da voçoroca consiste em determinar a relação dos desníveis e distâncias entre pontos notáveis que melhor representem os traços do desenho da erosão. A partir de um ponto, cujas coordenadas de latitude, longitude e altitude são conhecidas, é possível determinar a localização das três coordenadas para outro ponto qualquer no terreno, utilizando-se de dados de distância, ângulos azimutais e zenitais, e conceitos de trigonometria. $\mathrm{O}$ equipamento utilizado para as mensurações foi uma Estação Total da Leica, modelo TC 407, de precisão angular de 7" e linear de $2 \mathrm{~mm}+2 \mathrm{ppm}$, garantindo melhor confiabilidade aos dados coletados. Pode-se comparar a Estação Total a um teodolito digital, que calcula as relações trigonométricas e as armazena diretamente num banco de dados interno ao aparelho, facilitando e agilizando o trabalho desenvolvido em campo e escritório.

Para a representação da voçoroca, foram determinadas quatro vertentes principais para a coleta dos pontos notáveis na vertical: as duas margens, esquerda e direita, em contato com o nível d'água (VIE e VID, respectivamente); e as duas margens superiores, esquerda e direita (VSE e VSD, respectivamente), na ruptura do talude em erosão com o resto do terreno (Figura 11). Em ocasiões específicas foram coletados pontos intermediários (pI) de forma a garantir a precisão final do desenho computacional.

A distribuição dos pontos notáveis coletados na horizontal para cada vertente, ou seja, que representam, na vista em planta, os limites da erosão linear, foi realizada de forma a representar estes limites com precisão, como demonstrado na Figura 12. Regiões lineares constantes permitem a alocação de pontos mais distantes sem perda relevante de informação no desenho final. Locais que apresentam curvatura dos limites estipulados exigem coleta de pontos mais próximos a fim de garantir estas informações.

Pontos de controle (pC), que caracterizam as feições do terreno original, foram distribuídos ao longo do terreno distante do processo erosivo em estudo.

No levantamento topográfico, de todos os pontos coletados, foi atribuído um sistema de localização arbitrário local (valores de latitude, longitude e altitude adotados), devido às distâncias de marcos geodésicos e de referências de nível, e adotado os procedimentos contidos na Norma Brasileira Revisada NBR 13.133 de 1994 da Associação Brasileira de Normas Técnicas (ABNT). Após a coleta de dados, o georreferenciamento dos pontos coletados foi realizado com um GPS Leica Geosystems GS20, para a aquisição de valores de latitude e longitude no elipsóide WGS84 em pontos conhecidos da coleta. 


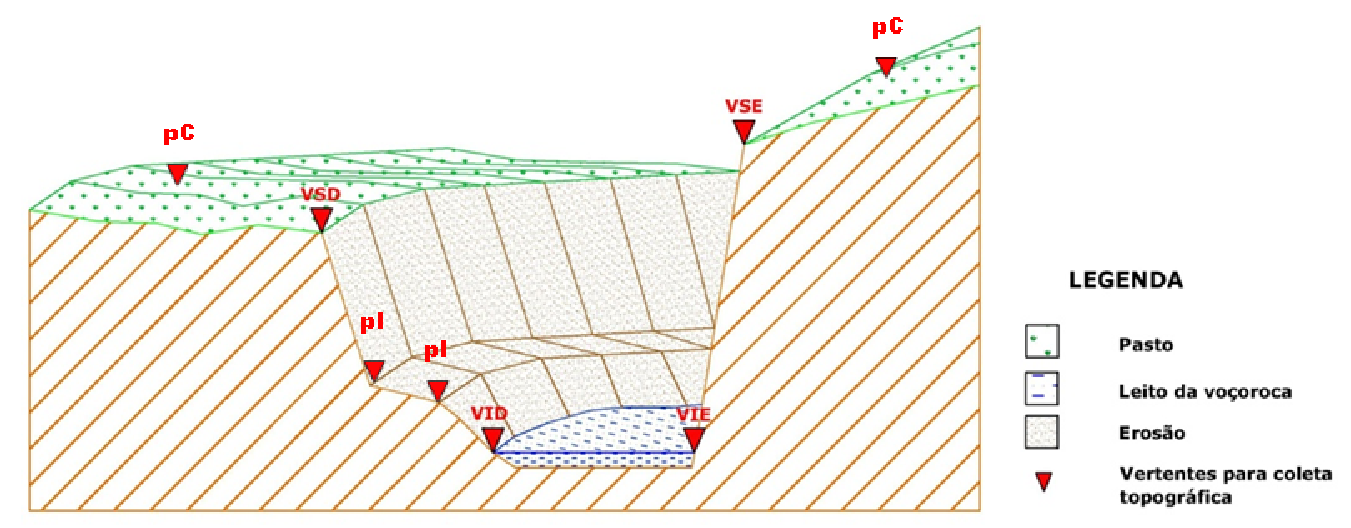

Figura 11. Corte transversal da voçoroca com as vertentes superiores direita e esquerda (VSD/VSE), vertentes inferiores direita e esquerda (VID/VIE), pontos intermediários (pI) e pontos de controle (pC).

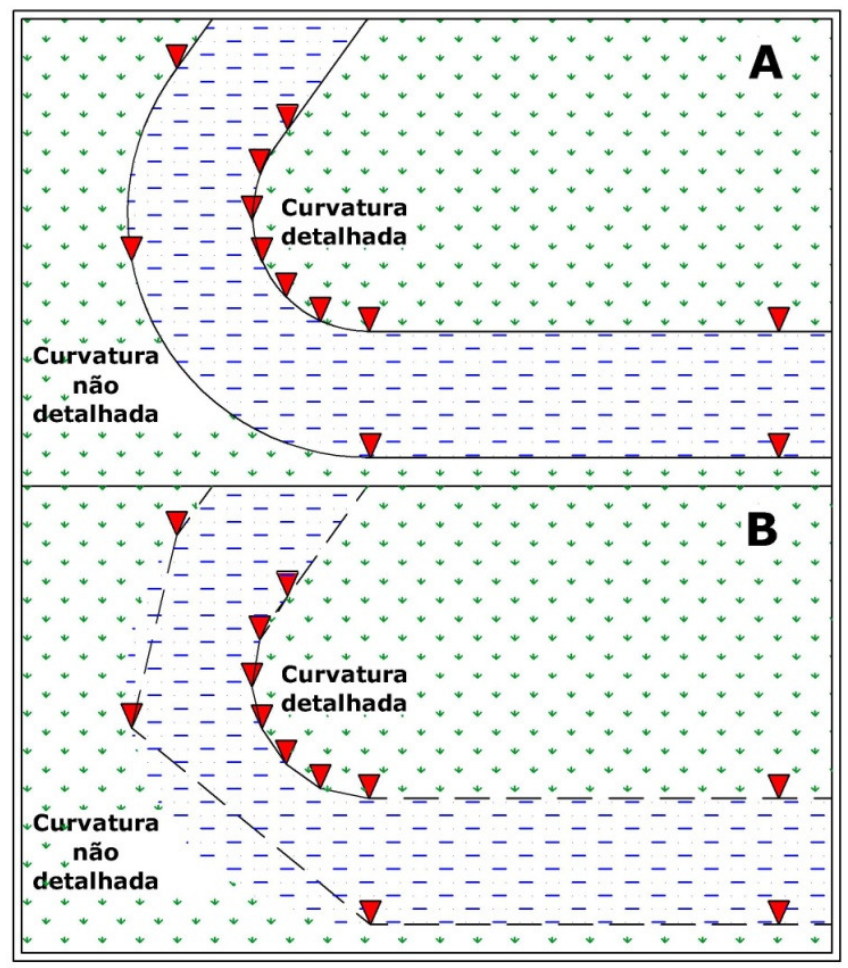

\section{LEGENDA}

Pasto

Leito da voçoroca

Horizonte original

Horizonte digitalizado

Pontos de coleta topográfica

Margem original

União dos pontos topográficos

Figura 12. Corte longitudinal da voçoroca com alocação adequada dos pontos notáveis horizontais.

\subsubsection{Análise de consistência e tratamento de dados}

Após a coleta de dados se faz necessário a análise de sua consistência, a fim de se eliminar ou corrigir dados anômalos ao observado em campo. Erros caracterizados como grosseiros podem ocorrer devido ao mau funcionamento do equipamento, desatenção do operador ou falhas não previstas, se tornando prudente a análise crítica da coerência das informações adquiridas. 
Através da conexão do aparelho de medição a um computador com um cabo de porta serial, os dados foram extraídos do equipamento por meio do software Posição da Manfra \& Cia Ltda. Este software, munido das informações coletadas em campo, realiza automaticamente os cálculos das relações trigonométricas inerentes a topografia, relação de "vante" e "ré" das estações e seus pontos irradiados, e o caminho percorrido pela poligonal adotada. O programa ainda disponibiliza os resultados em formato de tabela contendo, dentre outros, os valores referentes à latitude, longitude e altitude para cada ponto coletado, e em extensões compatíveis para leitura em softwares de desenho gráfico.

O software de desenhos gráficos de mapeamento adotado foi o AutoCAD Map 3D da Autodesk, devido a interface amigável de fácil compreensão, e compatibilidade dos arquivos gerados com o software de SIG adotado, ArcView 9.3 da ESRI.

Nesta etapa, foram atribuídos aos pontos as informações referentes ao seu georreferenciamento, deslocando e rotacionando o desenho para as coordenadas adotadas, e traçados os limites VSE, VSD, VIE, VID, e estradas com a função $3 D$ Polyline, disponibilizada pelo software.

A função $3 D$ Polyline cria linhas que adotam, em cada um de seus vértices, os valores de latitude, longitude e altitude associadas aos pontos ligados, de modo a representar o desenho resultante em três dimensões. Esta característica permite a subdivisão da linha resultante em vários pontos com a ferramenta Divide, aos quais são atribuídas as informações das três coordenadas através da interpolação linear dos seus vértices, gerando assim informações secundárias adicionais a análise.

Por fim, os dados tratados e gerroferenciados foram exportados em formato de extensão shape, compatível com o software ArcView 9.3.

\subsubsection{Cálculo do solo erodido}

A aquisição e tratamento dos dados topográficos, referentes às feições do terreno erodido, fornecem a base de dados primários à análise e construção dos MDT's de caracterização volumétrica do terreno com e sem a presença da voçoroca. Os pontos caracterizados por latitude, longitude e altitude são alocados pelo software ArcView 9.3 em uma superfície segundo o geóide e o sistema de coordenadas adotados a fím de se realizar os cálculos de modelação fornecidos pelo programa.

A modelação adotada para elaboração do MDT foi o modelo por redes irregulares de triangulação - TIN (Triangulated Irregular Network), devido às irregularidades nítidas do 
terreno em estudo e pelo seu amplo uso por sua eficiência em armazenar pontos de elevação irregularmente distribuídos. Em um TIN, os vértices descrevem feições nodais, como a ruptura de talude observadas em grandes erosões, enquanto que os lados representam feições lineares, como as paredes e o fundo plano da voçoroca.

No entanto, a utilização apenas dos dados primários, dados originais coletados em campo, para a modelação digital do terreno não se mostraram suficientes. No processo de interpolação linear utilizada pelo TIN, pontos mais próximos se mostram mais favoráveis a interagirem no processo de formulação dos triângulos enquanto que pontos distantes não se relacionam diretamente. Neste caso, em regiões lineares em que os pontos coletados estão distantes entre si e que deveria haver uma mudança brusca na angulação do terreno, caracterizado pelo início do talude da erosão, o modelo não realiza a triangulação corretamente, descaracterizando a feição real observada em campo. Deste modo, a fim de se garantir a modelação correta do terreno, foi feita a opção por realizar a inclusão de pontos secundários com a ferramenta Divide.

Este processo se torna viável devido à alocação estratégica dos pontos coletados em campo como mencionado anteriormente. É permitido assim, afirmar que os pontos secundários, criados a partir da interpolação linear, caracterizam a feição real do terreno e que portanto, podem ser utilizados no processo de modelação digital do terreno como dados confiáveis.

Desta forma, foram utilizados dados primários e secundários para a elaboração dos MDT's que caracterizam as feições do terreno original e erodido.

Para a modelagem do terreno erodido, com a presença da voçoroca, foram utilizados todos os dados coletados e gerados, caracterizando as condições atuais do terreno. Já para a modelagem da feição do terreno original, anterior ao processo erosivo linear, foram utilizados apenas os dados referentes aos pontos de controle, $\mathrm{pC}$, e os dados referentes as vertentes superiores da erosão, VSD e VSE, desconsiderando a presença da erosão.

O cálculo do volume dos MDT's foi realizado pelo software ArcView 9.3, com a ferramenta Surface Volume, contido na pasta Functional Surface. Esta ferramenta calcula o volume contido abaixo de um plano fictício que corta o MDT em uma cota determinada pelo usuário. Neste caso foi adotada a cota referente ao ponto mais elevado do modelo.

A subtração entre os volumes obtidos para o MDT do terreno original e do terreno erodido, fornece o volume de solo perdido pelo processo erosivo e, consequentemente, transportado ao corpo d'água represado. 


\subsubsection{Quantificação do volume do assoreamento no Ribeirão das Cruzes entre os} anos de 1967 e 2011

Da mesma forma em que foi calculado o volume de solo perdido pela erosão, foi realizada a mesma sequencia de operações para o cálculo do volume assoreado no tributário Ribeirão das Cruzes.

Dados de batimetria para o curso d'água, adquiridos em levantamento de campo realizado em 2011 e 2008 pelo Núcleo de Hidrometria, do CRHEA/SHS/EESC/USP, em São Carlos (SP), foram transformados em um modelo digital de terreno e subtraídos, através de operações booleanas do software ArcView 9.3, do MDT do terreno original, anterior ao enchimento da barragem da UHE de Três Irmãos. O resultado final pode ser considerado como a evolução do volume de material depositado no leito do Ribeirão das Cruzes ao longo dos anos de existência da represa.

\subsubsection{Modelo digital do terreno original, anterior ao enchimento da barragem da UHE Três Irmãos}

Devido ao início do processo erosivo em estudo ser anterior ao levantamento batimétrico realizado em 2008, para aprimoramento da análise do processo de assoreamento do canal do Ribeirão das Cruzes, através de comparação de volume erodido com volume assoreado, é necessário o conhecimento prévio das condições do terreno inundado a fim de se justificar a comparação pretendida. Assim, devido a não existência de estudos batimétricos anteriores ao realizado pelo núcleo de hidrometria, optou-se pelo uso das cartas topográficas 1:50.000 do Instituto Geográfico e Geológico de São Paulo (IGGSP), primeira edição 1967, como base de dados para representação das condições originais do terreno, anterior ao enchimento da barragem da UHE Três Irmãos.

As cartas necessárias à determinação do MDT, descritas na Tabela 3, foram adquiridas em formato analógico, sendo necessária sua conversão para formato digital, compatível com as linguagens computacionais. Para este processo foi utilizado um "scanner" que "rasteriza" o documento cartográfico, armazenando a informação contida em cada quadrícula micrométrica deste (COSTA, 2009). 
Tabela 3. Lista de cartas digitalizadas.

\begin{tabular}{cc}
\hline Nome & Identificação \\
\hline Aracanguá & SF-22-D-III-4 \\
Auriflama & SF-22-X-A-IV-2 \\
\hline
\end{tabular}

Durante o processo de "rasterização" o computador atribui às imagens coordenadas aleatórias que necessitam ser convertidas para um sistema de referência espacial conhecido, a fim de se padronizar as informações dos dados a serem comparados ou sobrepostos. Este procedimento deve ser realizado com o auxílio de um SIG ou software de desenho gráfico, através do georreferenciamento das imagens TIF provenientes da "scannerização". O software utilizado foi o AutoCAD MAP 2012 e o sistema de referência espacial adotado consiste no mesmo utilizado pelo IGGSP (1967a; 1967b), UTM Córrego Alegre 22 Sul.

Ainda assim, o computador não processa as informações sobrepostas contidas nas cartas como hidrografia, altimetria, pontos notáveis, malha viária, etc. sendo necessária a individualização das entidades "rasterizadas" através da vetorização com primitivas geométricas: pontos, linhas e polígonos. Nesta digitalização ou vetorização, que deve ser realizada manualmente, o operador persegue cada feição "raster" com o cursor, tendo como base a imagem TIF georreferenciada ao fundo, desenhando as primitivas geométricas (COSTA, 2009).

As feições digitalizadas necessárias à formulação do MDT foram as curvas topográficas e hidrografia com "linhas" e os pontos notáveis do terreno com "pontos".

Os dados digitalizados no AutoCAD MAP foram, então, transferidos em formato SHAPE (.shp) compatível com a leitura computacional do ArcView.

Devido ao maior nível de detalhamento do terreno contido nas cartas topográficas digitalizadas, para efeito de comparação com as batimetrias de 2008 e 2011, foram selecionadas as informações de altimetria do interior da represa que coincidem com as seções planejadas e utilizadas nas batimetrias. Deste modo, pontos espaçados a cada $90 \mathrm{~cm}$, semelhante aos dados coletados com o ecobatímetro, contendo as informações de latitude, longitude e altimetria foram criados com base nos transectos das coletas batimétricas, curvas de nível e fundo de vale (rios). Ao final, os dados foram exportados para o ArcView.

Para aprimoramento do MDT final que foi obtido, a hidrografia foi utilizada como "fundo de vale" em sua elaboração, atribuindo valores de cotas aos rios através de interpolações lineares das distâncias dos percursos dos rios entre duas curvas de nível consecutivas. 
A modelação digital do terreno foi realizada com a interpolação TIN.

\subsubsection{Delimitação do perímetro do alagamento}

A representação das cartas topográficas do IGGSP (1967) em um modelo digital de terreno também foi destinada ao traçado dos limites da represa em sua cota máxima de enchimento, 328,4 metros. Através do processamento das informações do MDT pela ferramenta TIN Contour contido nas funções TIN Surface do ArcView 9.3, foi delineado e criado um arquivo do contorno da represa, utilizado como referência nos cálculos de assoreamento e limite do espelho d'água.

\subsubsection{Delimitação das bacias hidrográficas}

A ESRI, empresa responsável pela elaboração e comercialização do software ArcView 9.3, disponibiliza em seu website a extensão Whatershed Delineation Tools que possui a ferramenta Watershed Delineation capaz de calcular e delimitar as bacias hidrográficas de uma região, com base na resolução espacial de um MDT raster fornecido pelo usuário.

Para a delimitação da bacia hidrográfica do Ribeirão das Cruzes e da voçoroca foi utilizado o mesmo modelo digital de terreno gerado para a área, a partir das cartas topográficas do IGGSP de 1967, convertendo o modelo vetorial TIN em modelo raster de resolução espacial de 1 metro. O critério adotado para a determinação da resolução espacial apenas buscou garantir maior precisão ao MDT final e, consequentemente, ao traçado da bacia hidrográfica.

\subsubsection{Levantamentos batimétricos}

Em se tratando de estudos que acompanhem as taxas de assoreamento de corpos d'água, a metodologia por levantamentos batimétricos é a mais confiável, conhecida e difundida no meio acadêmico por representar a situação real em que se encontram os corpos hídricos. A batimetria consiste em um levantamento detalhado do relevo da "seção molha" ou parte submersa da seção transversal.

No presente estudo foram utilizadas duas campanhas batimétricas a fim de se comparar o processo de sedimentação ao longo dos anos na região represada do Ribeirão das Cruzes.

A primeira batimetria obtida para a região foi realizada no ano de 2008 pelo Núcleo de Hidrometria do CRHEA/EESC/USP, por meio de um convênio de projeto de pesquisa e 
desenvolvimento entre a concessionária responsável pela UHE Três Irmãos, Cia Energética de São Paulo (CESP), a Agência Nacional de Energia Elétrica (ANEEL) e a Fundação para o Incremento da Pesquisa e do Aperfeiçoamento Industrial (FIPAI)/Escola de Engenharia de São Carlos (EESC). O intuito do projeto era atualizar os dados de cota $\mathrm{x}$ área $\mathrm{x}$ volume para adequar a operação da Usina a nova realidade da represa e mapear regiões com elevado processo de assoreamento no seu interior.

A campanha foi realizada para toda a extensão dos $785 \mathrm{~km}^{2}$ de área alagada no nível de água máximo, com seções planejadas numa configuração contínua, em "zigue-zague", caracterizando transectos paralelos, perpendiculares ao eixo longitudinal do curso d'água e espaçados em aproximadamente $1,5 \mathrm{~km}$ cada um, totalizando 500 seções.

Para o tributário em estudo, o Ribeirão das Cruzes, o mesmo padrão foi seguido totalizando 33 seções mensuradas no dia 25 de março de 2008.

O planejamento das seções foi realizado no software Hypack, demarcando o caminho que o barco deveria percorrer para capturar os dados de profundidade com o ecobatímetro. Ainda com o auxílio de um DGPS, o software identificou as coordenadas, auxiliando a navegação em campo, e as armazenou em um banco de dados associadas aos valores de profundidade mensurados pelo ecobatímetro.

Assim, os equipamentos utilizados para a realização das campanhas de batimetria foram: ecobatímetro modelo BATHY - 500MF da SyQwest Inc., mono feixe na frequência de $200 \mathrm{khz}$ (equipamento que mede a profundidade) com transdutor das ondas, receptor GPS Leica Geosystems GS20 com correções diferenciais (DGPS), computador de bordo equipado com o software Hypack para o mapeamento hidrográfico, gerador de energia e barco com motor de popa.

Para efeito de comparação entre as duas batimetrias executadas no Ribeirão das Cruzes, a segunda campanha em 02 de setembro de 2011 foi realizada com os mesmos equipamentos e planejamento das seções batimétricas da campanha de 2008.

Os técnicos hidrometristas do Núcleo de Hidrometria responsáveis pela campanha de 2008 foram José Roberto Maramarque e Waldomiro Antônio Filho. Para a campanha de 2011 apenas o técnico Waldomiro Antônio Filho foi responsável pela coleta dos dados.

\subsubsection{Análise de consistência e tratamento de dados}

Assim como na topografia, os dados coletados nas campanhas batimétricas estão sujeitos a erros oriundos de diversas falhas e que necessitam de correção por parte do 
operador. É comum em aparelhos como o ecobatímetro a perda de sinal em algum momento na coleta de campo, acusando elevação 0 metros, seja por oscilação da energia que alimenta o aparelho, solavancos de ondas ou erro do próprio equipamento, resultando em dados anômalos de fácil percepção. Também são apresentados erros com relação a "leitos falsos" como a presença de vegetação submersa, troncos de árvores ou demais bloqueios que impeçam a onda sonora de atingir o fundo real do canal. Pela presença inevitável de todos estes casos de anomalia, os dados coletados foram tratados no software Hypack, eliminando dados incoerentes e suavizando as curvas que representam o corte transversal da seção batimétrica.

No software Hypack os dados foram exportados contendo informações sobre as coordenadas geográficas (latitude e longitude) e a profundidade de todos os pontos de cada transecto e, então, foram trabalhados na planilha eletrônica do Microsoft Excel.

Como no ecobatímetro os dados de profundidade são fornecidos considerando o transdutor das ondas como cota 0 metros, faz-se necessário a transformação em altitude através da subtração dos valores obtidos do valor registrado na régua linimétrica do reservatório para o dia da coleta, além de considerar a profundidade em que estava submerso o transdutor das ondas.

Os dados referentes ao nível de água na régua foram fornecidos gratuitamente pela CESP através do serviço de informação por telefonia chamado "TeleCheia 08006479001".

Os dados tratados, já com a altimetria corrigida no software Microsoft Excel, foram salvos em um editor de texto com a extensão computacional SCRIPT (.scr), em formato compatível com a leitura do software de desenho gráfico AutoCAD MAP 2012. Esta etapa apenas auxiliou a transferência das informações dos dados coletados para o software de modelação de terreno ArcView 9.3. Os dados inseridos no AutoCAD MAP foram, então, retransferidos em formato SHAPE (.shp) compatível com a leitura computacional do ArcView.

\subsubsection{Cálculo do volume de assoreamento}

A aquisição e tratamento dos dados batimétricos, referentes às feições do terreno inundado pela barragem da UHE Três Irmãos e o limite estipulado em 328,4 metros para a cota máxima da água, fornecem a base de dados à análise e construção dos MDT's de caracterização volumétrica do terreno. Os pontos caracterizados por latitude, longitude e altitude são alocados pelo software ArcView 9.3 em uma superfície segundo o geóide e o 
sistema de coordenadas adotados a fim de se realizar os cálculos de modelação fornecidos pelo programa.

Assim como o cálculo do volume dos MDT's da erosão linear, o mesmo procedimento foi empregado para os dados de batimetria, utilizando-se da ferramenta Surface Volume, contido na pasta Functional Surface, do software ArcView 9.3.

O plano fictício, estipulado para cálculo do volume que preenche a parte inferior desta superfície, foi a cota maxi maximorum que corresponde ao espelho d'água em sua cota de maior elevação.

Foram quatro as situações para o cálculo do volume submerso: os dados referentes às batimetrias realizadas em 2011 e 2008, os dados para as seções batimétricas de 1967 segundo as cartas do IGGSP, e os dados contendo todas as informações das cartas do IGGSP (1967).

A subtração entre os diversos volumes encontrados caracterizou a evolução do processo de assoreamento do canal e a comparação entre os dois volumes obtidos segundo as cartas do IGGSP (1967), o erro associado à perda de informação em levantamentos batimétricos. 


\section{RESULTADOS E DISCUSSÃO}

\subsection{Análise da existência da voçoroca}

Com base na análise visual das imagens disponibilizadas pelo INPE (Figura 13), foi possível notar uma mudança significativa entre as imagens geradas em 27 de julho de 2004 e 20 de fevereiro de 2005. A região do delta da erosão se apresenta mais clara na imagem de 2005, caracterizando a presença do solo exposto/erodido, enquanto que na imagem de 2004, a mesma região se encontrava preenchida por água.

Para confirmação do período de surgimento da erosão, foram analisadas imagens anteriores e posteriores ao período descrito. Nas imagens de 08 de março de 2005, 11 de março de 2006 e principalmente 14 de março de 2007 fica nítida na constituição das cores a consolidação da voçoroca no terreno, em comparação com as imagens mais antigas, 20 de abril de 2004 e 28 de abril de 2003. Portanto, devido à inexistência de mais imagens entre o

período de 27/07/2004 e 20/02/2005, para efeito deste estudo, foi considerado o desencadeamento da voçoroca em agosto de 2004. 

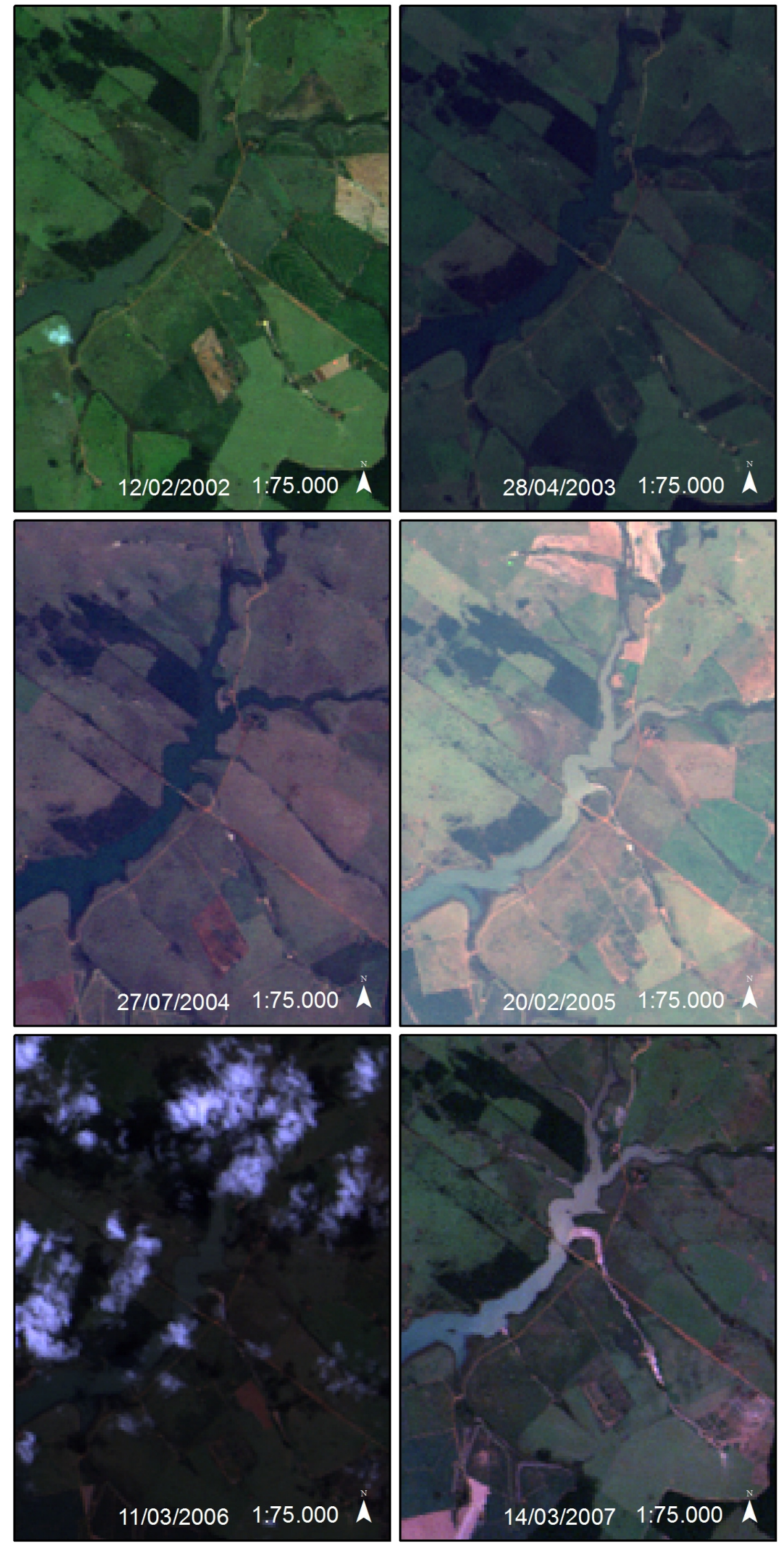

Figura 13. Imagens históricas de sensoriamento remoto Landsat TM5 para a região da voçoroca. 


\subsection{Quantificação do volume do solo erodido na voçoroca}

\subsubsection{Levantamento topográfico}

Na realização do levantamento topográfico foi adotado o sistema por poligonal aberta. Estacas de madeira foram utilizadas para demarcar os pontos exatos de cada estação, a fim de se eternizar os marcos para coletas futuras e minimizar erros nas demarcações de "vante" e "ré".

Devido a grande extensão, aproximadamente $3 \mathrm{~km}$, e as características de forma física do processo erosivo, como o surgimento de meandros e irregularidades que obstruem o ângulo de visão da luneta da Estação Total, o avanço da coleta se deu, em grande parte, pelo interior da voçoroca (Figura 14), afim de se garantir a visão de todas as características e feições internas a erosão.

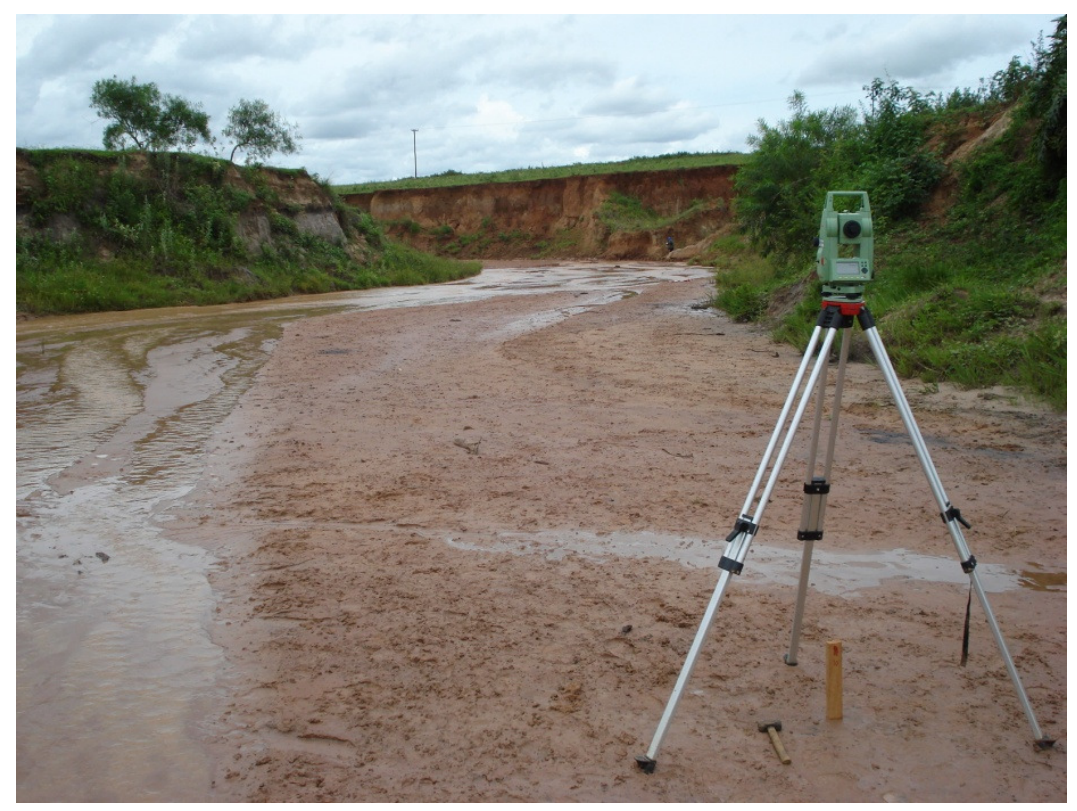

Figura 14. Coleta de pontos: Estação Total no interior da voçoroca.

Ao total foram estabelecidas 31 estações para a poligonal aberta a partir das quais foram coletados 2.576 pontos de irradiação sendo: 2.402 de caracterização da voçoroca e 174 de caracterização do terreno no entorno (pC). Notas e observações a respeito das características de localização dos 2.607 pontos e ainda a classificação em VIE, VID, VSE, VSD, pI, pC e Estação foram registradas manualmente durante a coleta de campo a fim de se evitar confusões no processamento dos dados em escritório.

A região levantada com a topografia limitou-se à jusante da voçoroca, quando esta entra em contato com o espelho d'água da área alagada do Ribeirão das Cruzes, e a montante 
no início do processo erosivo. Na região da cabeceira da erosão, o processo erosivo se divide em diversos sulcos de baixa profundidade que se entrelaçam e dificultam sua representação gráfica. Optou-se por desprezar as informações topográficas referentes a esta área, uma vez que o volume de solo erodido nesta região se torna insignificante perante o restante da erosão à jusante.

Devido a distância da área de estudo da presente pesquisa e as características físicas já mencionadas da erosão, o levantamento topográfico, realizado com estação total de precisão, foi concluído em duas campanhas de visita a campo. A primeira em Janeiro de 2011 e a segunda em Setembro de 2011.

Duas estações da poligonal aberta, distantes entre si, foram escolhidas para a coleta de dados de georreferenciamento (Tabela 4). A estação 2, devido ao bom estado de conservação do marco de estaca de madeira da primeira campanha a campo, e a estação 30 por estar distante da primeira referência e pela facilidade de acesso.

Tabela 4. Coordenadas geográficas WGS 84 e UTM Fuso 22 das estação do levantamento topográfico.

\begin{tabular}{ccc}
\hline Estação & Latitude & Longitude \\
\hline \multirow{2}{*}{02} & $20^{\circ} 49^{\prime} 34.7120^{\prime \prime} \mathrm{S}$ & $50^{\circ} 39^{\prime} 19.1156^{\prime \prime} \mathrm{O}$ \\
& $535864.676 \mathrm{~S}$ & $7697036.682 \mathrm{O}$ \\
\multirow{3}{*}{$\mathbf{3 0}$} & $20^{\circ} 50^{\prime} 37.7167^{\prime \prime} \mathrm{S}$ & $50^{\circ} 38^{\prime} 41.4359^{\prime \prime} \mathrm{O}$ \\
& $536949.454 \mathrm{~S}$ & $7695097.410 \mathrm{O}$ \\
\hline
\end{tabular}

\subsubsection{Análise de consistência e tratamento de dados}

Os dados coletados foram armazenados no banco de dados do software interno a Estação Total, facilitando e agilizando o trabalho desenvolvido em campo e escritório. Através da conexão do aparelho de medição e um computador com um cabo serial, os dados armazenados foram extraídos e tratados pelo software Posição da Manfra \& Cia Ltda. Não foram encontradas irregularidades ou erros aparentes nos dados coletados, restando apenas informar ao software os pontos que definem as estações da poligonal aberta, realizada durante o levantamento de campo. Os demais pontos são automaticamente classificados pelo software como irradiações das estações.

$\mathrm{O}$ arquivo completo foi salvo com a extensão . $d w g$ compatível com o software de desenho gráfico AutoCAD Map 3D. Neste software, o arquivo contendo os dados distribuídos em um espaço de coordenadas arbitrárias foi georreferenciado, segundo o sistema universal convencional, UTM WGS84, de acordo a corresponder com os dados coletados com o GPS em campo. Para o georreferenciamento, o desenho foi deslocado no plano de modo a sobrepor 
o ponto da estação 02 com o ponto exato que o representa no plano de coordenadas UTM registradas com o GPS. As coordenadas UTM, assim como os levantamentos topográficos, são utilizadas para a representação em planta da superfície arredondada do globo terrestre, de forma a preservar características físicas do terreno como distâncias, áreas e volumes. Para longas distâncias este sistema de coordenadas apresenta distorções no valor real de medições, por desconsiderar a curvatura da superfície terrestre. A NBR 13.133 (1994) admite levantamentos topográficos de planos com até $80 \mathrm{Km}$ de distância, podendo o erro de distorção chegar a 3,00 metros. Porém, para a curta distância, aproximadamente $3 \mathrm{Km}$, que caracteriza o comprimento linear da erosão em estudo, a distorção se torna insignificante, 0,22 $\mathrm{mm}$ e, portanto, coerente com as informações coletadas na topografia quando na sobreposição dos planos de referência.

Assim, considerando um eixo de rotação do desenho da planta, adquirida com a topografia, no ponto da estação 02, o plano XY (coordenadas arbitrárias) em que estão contidos os demais pontos que caracterizam a voçoroca em estudo foi rotacionado de forma a coincidir a estação 30 mensurada com a Estação Total, com a estação 30 mensurada com o GPS. A rotação do plano XY de forma a coincidir com o plano UTM WGS 84, plano em que estão contidos os pontos coletados com o GPS, caracteriza o georreferenciamento do levantamento topográfico da voçoroca (Figura 15).

A
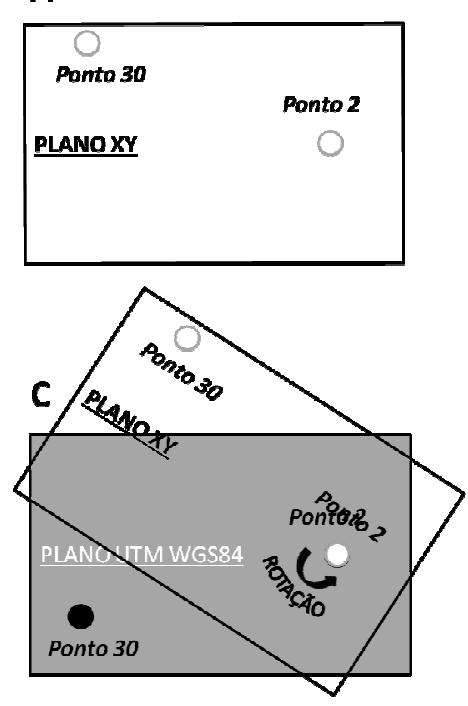

B
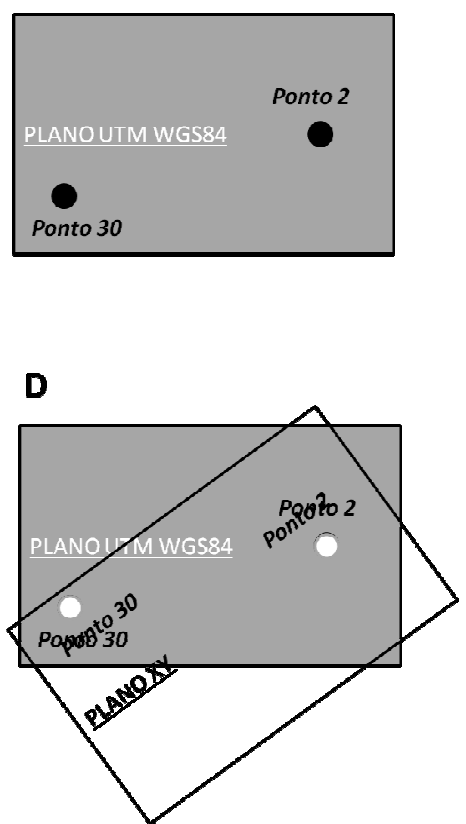

Figura 15. Exemplo de georreferenciamento de um plano XY em UTM WGS84. 
A distância entre o ponto 30 e sua real posição que deveria ocupar na coordenada UTM representa o erro propagado nas medições realizadas em campo, somado aos erros sistemáticos dos aparelhos Estação Total e GPS. O valor do erro encontrado corresponde a 1,8 metros $(\Delta \mathrm{X}: 0.885 ; \Delta \mathrm{Y}:-1.582)$, ou seja, o ponto 30 coletado na topografia ficou a 1,8 metros de distância de atingir e coincidir com seu valor de coordenadas UTM medidas com o GPS.

Os traçados realizados com a ferramenta $3 D$ Polyline e apresentados no Apêndice B representam os resultados obtidos no levantamento topográfico da voçoroca. Em vermelho estão representadas as vertentes/margens superiores, VSD e VSE, em azul as vertentes/margens inferiores, VID e VIE da erosão, e a região traçada em amarelo representa o delta da erosão, onde não há distinção de taludes nas laterais. Os pontos verdes correspondem aos pontos de controle no entorno da erosão. Os pontos intermediários não foram representados na vista em planta devido ao excesso de informações gráficas no mapa. Para efeito demonstrativo a Figura 16 ilustra, em uma escala maior, os pontos intermediários de uma região da erosão.

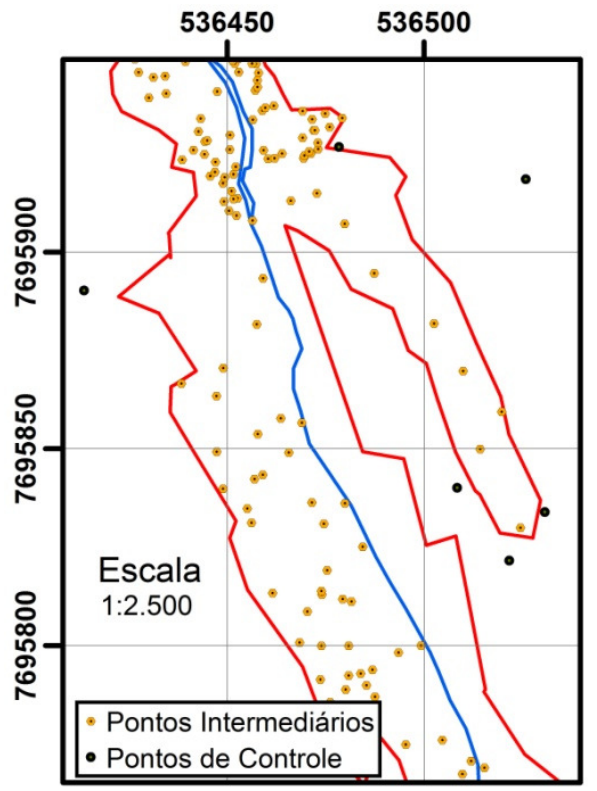

Figura 16. Distribuição dos pontos intermediários no interior da voçoroca.

Todas as linhas traçadas com a ferramenta $3 D$ Polyline foram subdivididas em pontos com a ferramenta Divide a fim de se obter dados extras para melhorar a interpolação na formulação do MDT da erosão (Figura 17 e Figura 18). A divisão em pontos extras apenas 
levou em consideração a garantia de proximidade entre os pontos, não adotando critérios fixos. Ao fim, foram criados 313.411 pontos extras.
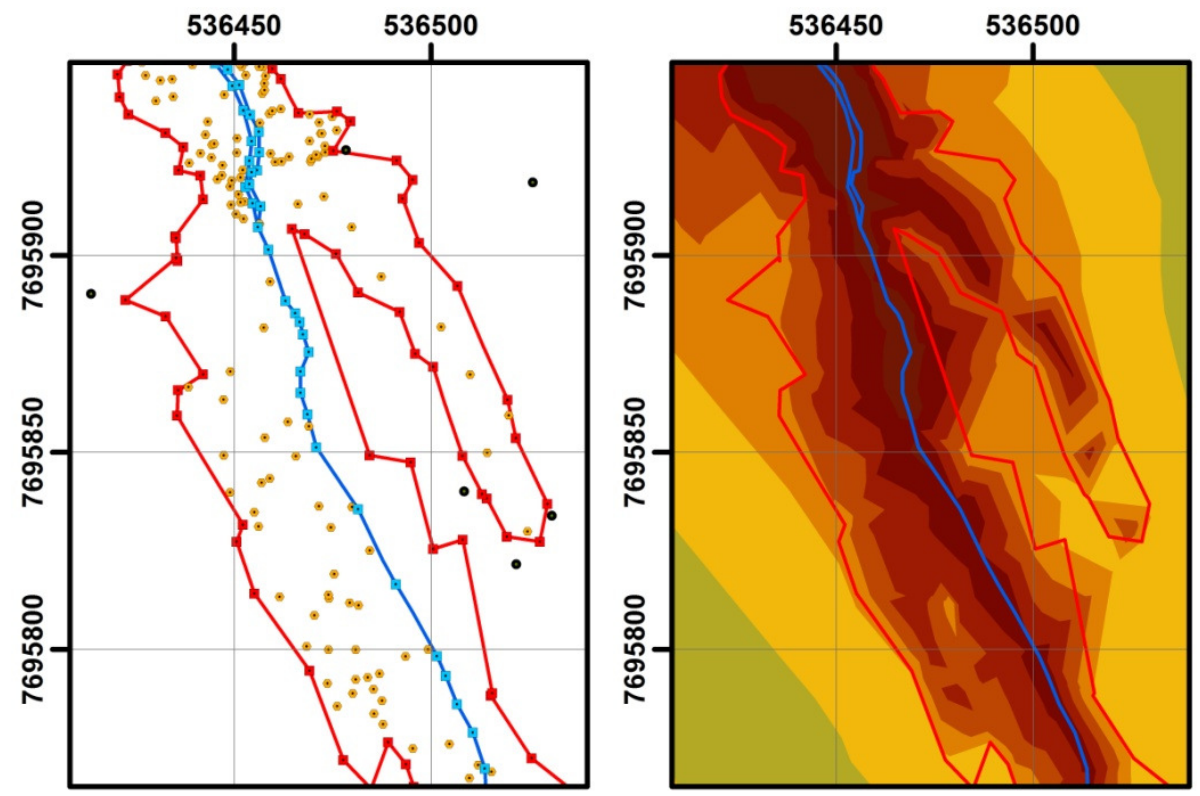

Figura 17. Exemplo da distribuição dos pontos coletados em uma região da voçoroca e o resultado obtido com a interpolação.
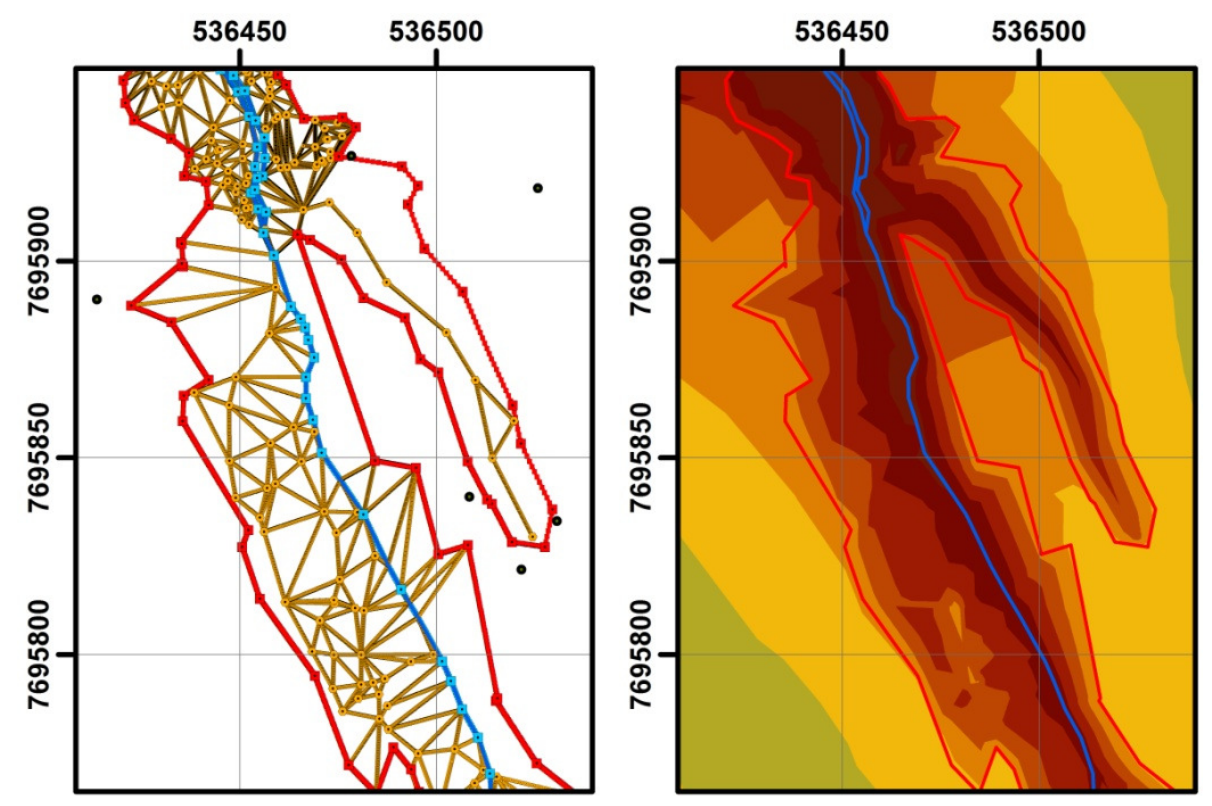

Figura 18. Exemplo da distribuição dos pontos coletados e acrescentados em uma região da voçoroca e o resultado obtido com a interpolação.

\subsubsection{Cálculo do solo erodido}

As informações de entrada utilizadas, para o cálculo do MDT do terreno com e sem a presença da erosão no software ArcView 9.3, foram divididas em seis categorias de layers: 
dados de pontos primários e secundários das vertentes superiores da erosão, VSD e VSE; dados de pontos primários e secundários das vertentes inferiores da erosão, VID e VIE; dados de pontos primários e secundários da região intermediária às quatro vertentes, pI; dados de pontos primários e secundários de caracterização das estradas que cruzam a erosão; dados de pontos primários e secundários da região do delta da erosão; e, dados primários de caracterização do terreno no entorno da erosão, pC.

As linhas traçadas com a ferramenta $3 D$ Polyline também foram transferidas ao software ArcView 9.3, apenas para efeito gráfico de delimitação das características do terreno, não sendo, portanto, utilizadas na elaboração dos modelos digitais do terreno.

Para o cálculo do MDT de caracterização da feição da voçoroca, foram utilizados todos os layers de dados disponíveis (6 layers). Os limites para o processamento dos dados foram estabelecidos pelo próprio programa, que limita a região do modelo nos pontos mais externos do desenho. $\mathrm{O}$ resultado final encontrado pode ser observado no Apêndice $\mathrm{C}$, no qual as curvas de nível, para um Datum vertical arbitrário, são representadas a cada 5 metros de elevação.

Já para a caracterização do terreno original, anterior ao surgimento do processo erosivo, foram utilizados 4 layers, excluindo apenas os layers das vertentes inferiores, VID e VIE e dos pontos intermediários, pI. Esta seleção de dados despreza os pontos coletados abaixo da linha do terreno, ou seja, os pontos que caracterizam unicamente as feições da voçoroca. Os limites estabelecidos pelo programa para elaboração do MDT permaneceram os mesmos, uma vez que os pontos mais externos permaneceram no cálculo do desenho final. $\mathrm{O}$ Apêndice D representa os resultados obtidos para o terreno original, com o mesmo Datum vertical arbitrário e espaçamento de curvas de nível do Apêndice $\mathrm{C}$, com cotas a cada 5 metros de elevação.

Ambos os mapas foram submetidos ao cálculo de volume que preenche a região entre o MDT obtido e o plano fictício que corta o modelo em seu ponto mais elevado, cota 852,564 m. Os resultados obtidos para a área 2D, 3D e o volume estão representados na Tabela 5.

Tabela 5. Resultados obtidos para os valores de área 2D, área 3D e volume para os MDT's da área de estudo com e sem a presença da voçoroca.

\begin{tabular}{ccc}
\hline Parâmetros & Terreno Original & Terreno Erodido \\
\hline Área 2D $\left(\mathbf{m}^{2}\right)$ & 845194,21 & 845224,05 \\
Área 3D $\left(\mathbf{m}^{\mathbf{2}}\right)$ & 847740,25 & 860526,04 \\
Volume $\left(\mathbf{m}^{\mathbf{3}}\right)$ & 24809427,37 & 25031202,04 \\
\hline
\end{tabular}


O valor de $29,83 \mathrm{~m}^{2}$ observado entre a diferença dos valores obtidos para as áreas $2 \mathrm{D}$ de ambos os terrenos representa a área em planta que não coincidiu em ambos os modelos de elevação do terreno. Portanto, a área em planta do MDT do terreno erodido é 29,83 $\mathrm{m}^{2}$ maior que a área em planta do MDT do terreno original. Apesar das áreas não coincidirem totalmente este erro foi desconsiderado uma vez que a área se torna irrelevante quando comparada com a área total, da ordem de $845.000 \mathrm{~m}^{2}$, observada para ambos os casos. Levando em consideração o desnível máximo levantado com a topografia para a área mensurada, aproximadamente 54 metros, o volume de erro máximo, dependendo da região onde se encontra a inclusão dos $29,83 \mathrm{~m}^{2}$ da área 2D extra, é de $1.610 \mathrm{~m}^{3}$.

A diferença de volume encontrada entre ambos os MDT's, 0,22 hm³ (221.774,68 $\left.\mathrm{m}^{3}\right)$, desconsiderando o erro oriundo da diferença das áreas, foi o valor adotado como sendo o volume real de sólidos erodidos lançado no interior da represa do Ribeirão das Cruzes, contribuintes ao processo de assoreamento.

\subsection{Quantificação do volume do assoreamento no Ribeirão das Cruzes entre os anos de 1967 e 2011}

\subsubsection{Modelo digital do terreno original, anterior ao enchimento da barragem da UHE Três Irmãos}

A região das cartas topográficas Santo Antônio do Aracanguá e Auriflama que compreende a área da bacia hidrográfica do Ribeirão das Cruzes, foram submetidas ao processo de digitalização no software AutoCAD MAP, após o georreferenciamento das imagens obtidas com a rasterização das cartas analógicas com um scanner.

Dados referentes às curvas de nível e hidrografia foram digitalizados com linhas, enquanto dados de pontos notáveis foram representados com pontos. Ao fim, todas as informações foram transferidas em formato SHAPE (.shp) compatível com o software de modelagem de terreno ArcView 9.3.

O georreferenciamento foi realizado distribuindo 9 pontos de latitude e longitude conhecidos ao longo da imagem, sendo 4 pontos nas extremidades, 4 pontos na região mediana do mapa e 1 ponto no centro da imagem (Figura 19). 


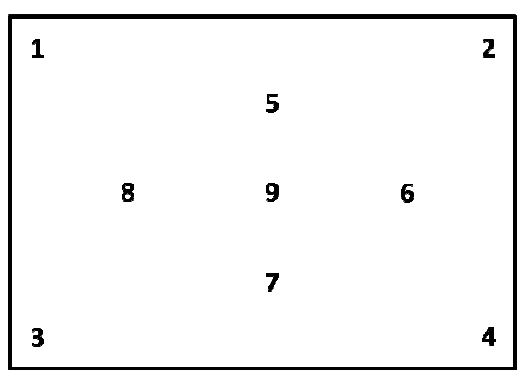

Figura 19. Distribuição dos pontos de georreferenciamento das cartas do IGGSP.

O cálculo de um MDT de uma bacia hidrográfica desconsidera em seu processamento informações referentes aos fundos de vale do terreno. Quando simulada a elevação do terreno para uma região plana de fundo de vale, em que as curvas de nível se apresentam distantes entre si e em forma de parábola, o software interpreta a região interpolando os dois lados da parábola da mesma curva de nível, resultando em uma região plana. Assim nesta área não é apresentada a região de fundo de vale, havendo perda relevante de informação para o cálculo do assoreamento (Figura 20).
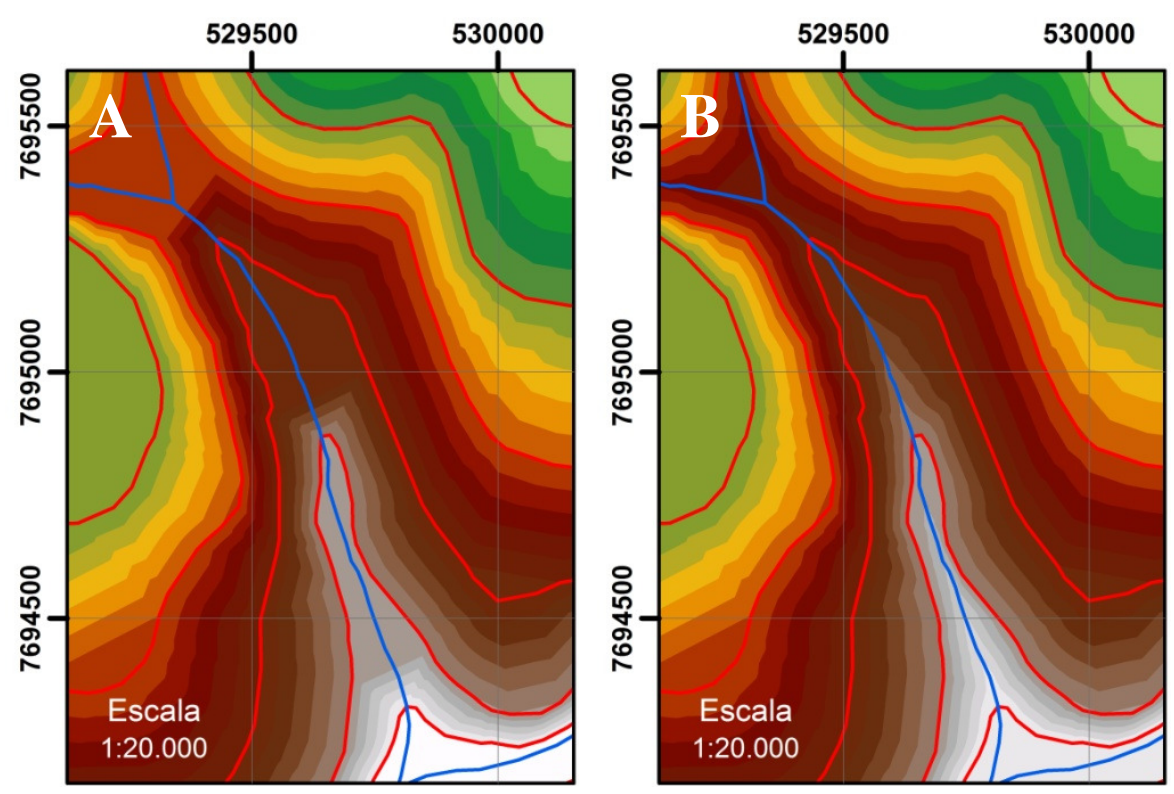

Figura 20. Exemplo de uma interpolação sem (A) e com (B) a consideração do fundo de vale.

O problema de fundo de vale foi resolvido atribuindo valores de altitude ao longo das hidrografias e considerando esta informação no processo de formulação do MDT. Para atribuir valores de cota aos rios da bacia hidrográfica foi realizado a metodologia de interpolação linear . Pontos foram inseridos e cotados segundo a distância percorrida pelo rio entre duas curvas de nível. 
O resultado final (Apêndice E) considera os fundos de vale se aproximando das feições reais do terreno.

As informações contidas no MDT gerado e tratado e o percurso dos dados coletados nas batimetrias de 2008 e 2011 foram utilizados para a formulação de uma batimetria fictícia para o ano de 1967.

\subsubsection{Delimitação do perímetro do alagamento}

A delimitação do perímetro do espelho d'água, para o alagamento do Ribeirão das Cruzes na altitude máxima permitida pelo represamento da UHE Três Irmãos, 328,4 metros, considerou o MDT gerado e corrigido das cartas do IGGSP (1967). O traçado final (Figura 21 e Apêndice E), obtido através da ferramenta TIN Contour, foi considerado inalterado ao longo dos anos e utilizado como limite de interpolação para todas as batimetrias. Apesar das mudanças no contorno do reservatório, na maioria dos casos, estarem subentendidas, esta decisão foi tomada devido à inexistência de cartas topográficas atuais para a região, dificuldades de tempo e distância para efetuar um levantamento topográfico atual de todo o perímetro da represa, além da restrição financeira para aquisição de imagens de satélite detalhadas para os períodos considerados.

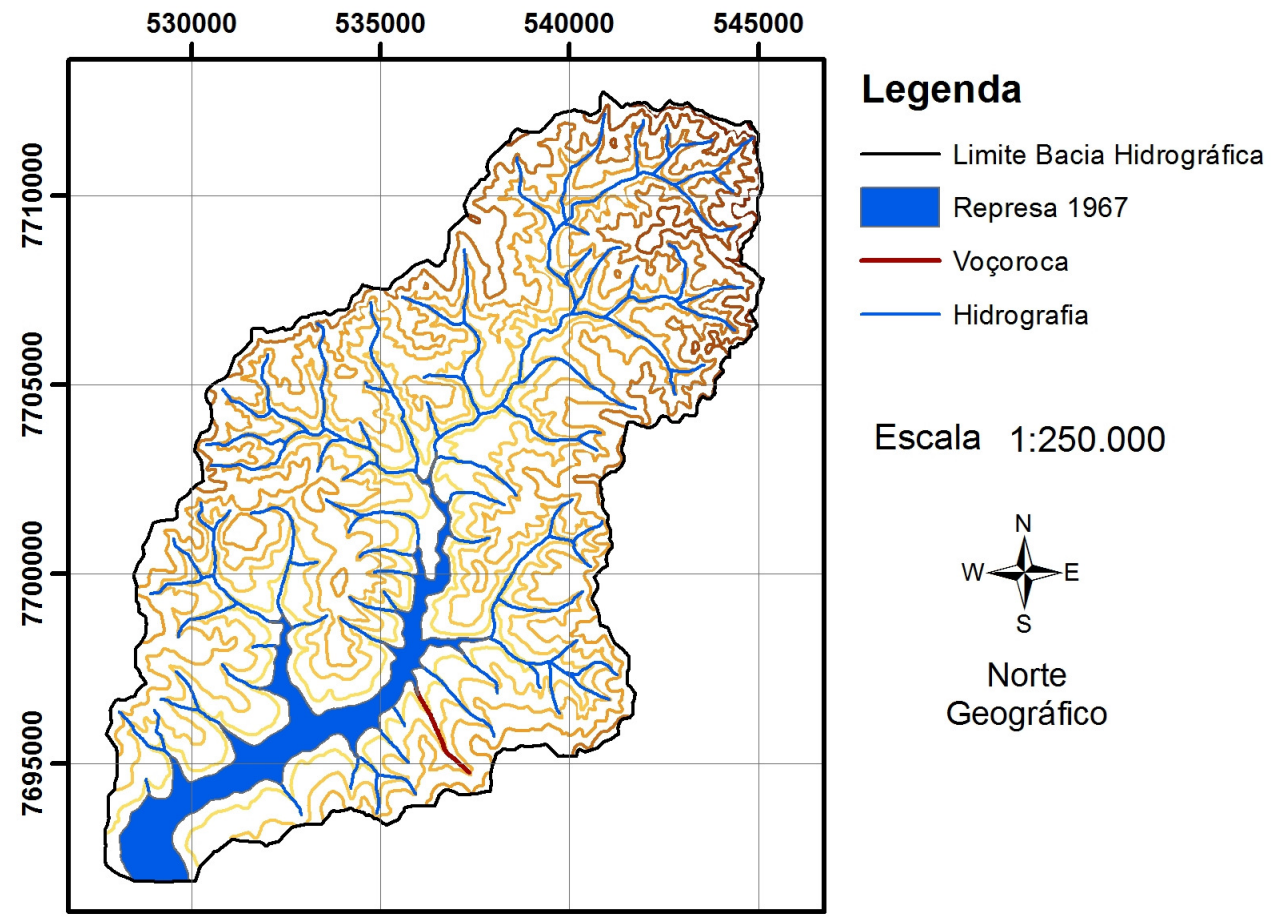

Figura 21. Distribuição dos elementos gráficos na bacia hidrográfica do Ribeirão das Cruzes. Datum horizontal: Córrego Alegre. Datum vertical: Tôrres (RS). 


\subsubsection{Delimitação das bacias hidrográficas}

A ferramenta Watershed Delineation, inserida no software ArcView 9.3 pela extensão Whatershed Delineation Tools, utilizou o modelo digital do terreno em formato raster, de resolução espacial de 1 metro, para fazer os cálculos necessários à delimitação das Bacias Hidrográficas na distribuição topográfica das cartas do IGGSP (1967). Com base nos dados de elevação do terreno para cada célula do modelo raster, a função utiliza a determinação do caminho preferencial percorrido pelos fluxos d'água no terreno para traçar as diversas microbacias hidrográficas ao longo da superfície analisada. As diversas bacias traçadas são retornadas em formato de polígono e cabe ao operador do software determinar quais polígonos pertencem à composição da Bacia Hidrográfica do Ribeirão das Cruzes e da erosão em estudo.

Os resultados obtidos para o mapeamento das bacias hidrográficas podem ser observados na Figura 22, que representa a área das bacias hidrográficas do Ribeirão das Cruzes e da Voçoroca.

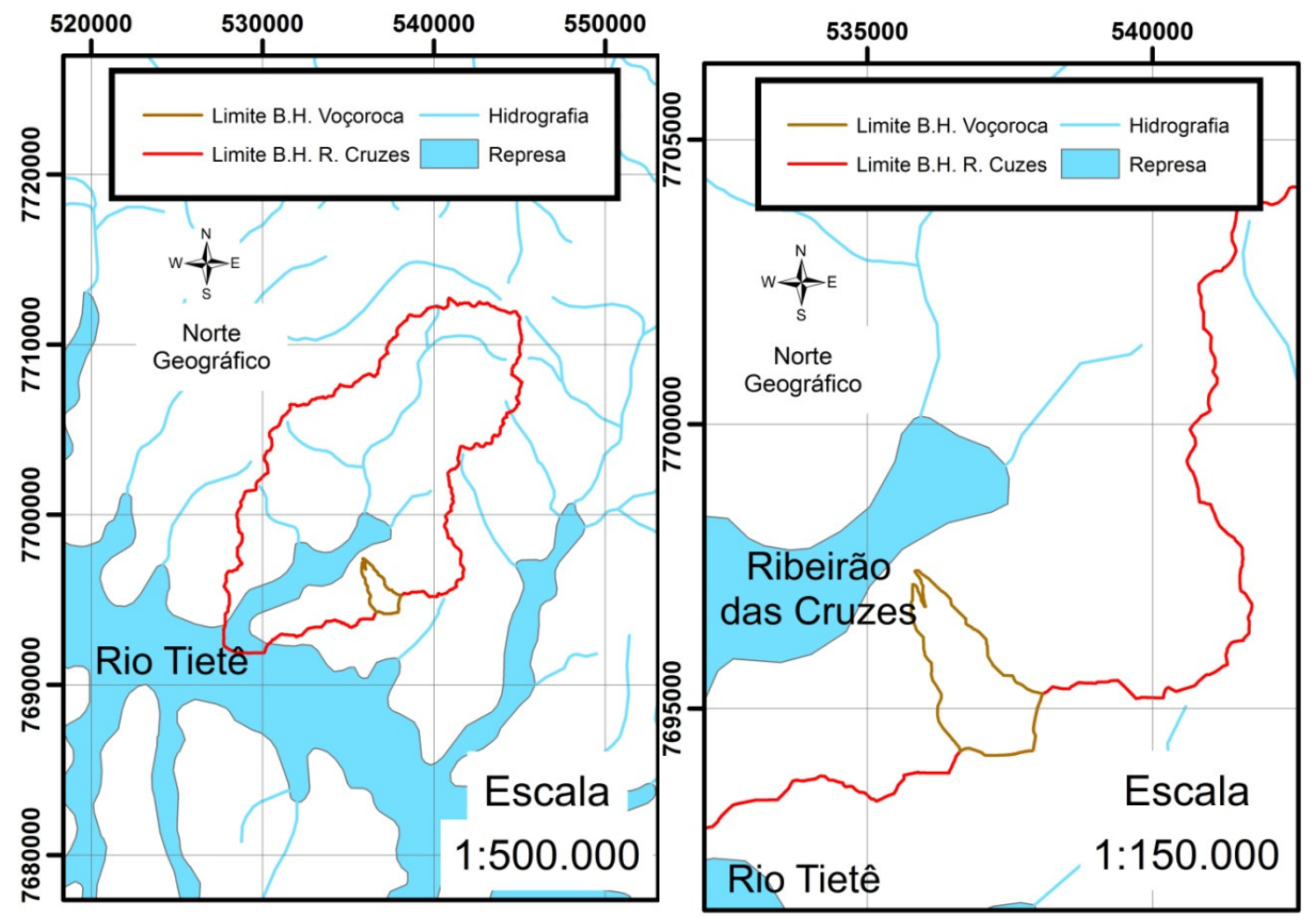

Figura 22. Traçado da bacia hidrográfica do Ribeirãos das Cruzes e traçado da bacia hidrográfica da voçoroca. Datum horizontal: Córrego Alegre.

Fonte: Adaptado de IGGSP (1967) e CETEC (2008). 
Os polígonos obtidos foram usados para "recortar" com a função clip o MDT da região, a fim de se calcular as áreas ocupadas pelas bacias hidrográficas com a ferramenta surface volume. A Tabela 6 demonstra os resultados obtidos para as áreas 2D e 3D das respectivas bacias hidrográficas e o Apêndice E representa o MDT da bacia hidrográfica.

Tabela 6. Resultados obtidos para os valores de área 2D e área 3D para as bacias hidrográficas do Ribeirão das Cruzes e da voçoroca.

\begin{tabular}{lcc}
\hline Parâmetros & $\begin{array}{c}\text { Bacia Hidrográfica do Ribeirão das } \\
\text { Cruzes }\end{array}$ & $\begin{array}{c}\text { Bacia Hidrográfica da } \\
\text { Voçoroca }\end{array}$ \\
\hline Área 2D $\left(\mathbf{m}^{\mathbf{2}}\right)$ & 207666178,14 & 3662578,34 \\
Área 3D $\left(\mathbf{m}^{2}\right)$ & 208218368,67 & 3670775,88 \\
\hline
\end{tabular}

\subsubsection{Levantamentos batimétricos}

Devido a insegurança da navegação provocada por intempéries climáticas e o tempo disponível para a coleta de dados em campo, a campanha realizada em setembro de 2011 não concluiu o levantamento de todos os transectos pretendidos para a comparação. Foram coletadas informações de 29 seções das 33 realizados na primeira campanha em março de 2008. As seções não mensuradas, a jusante do Ribeirão das Cruzes, foram as 4 mais próximas ao curso do rio Tietê. $\mathrm{O}$ traçado dos pontos de profundidade coletados pelo barco em ambas as campanhas e o traçado dos dados estipulado para a batimetria fictícia de 1967 estão exemplificados na Figura 23 e representados no Apêndice F.

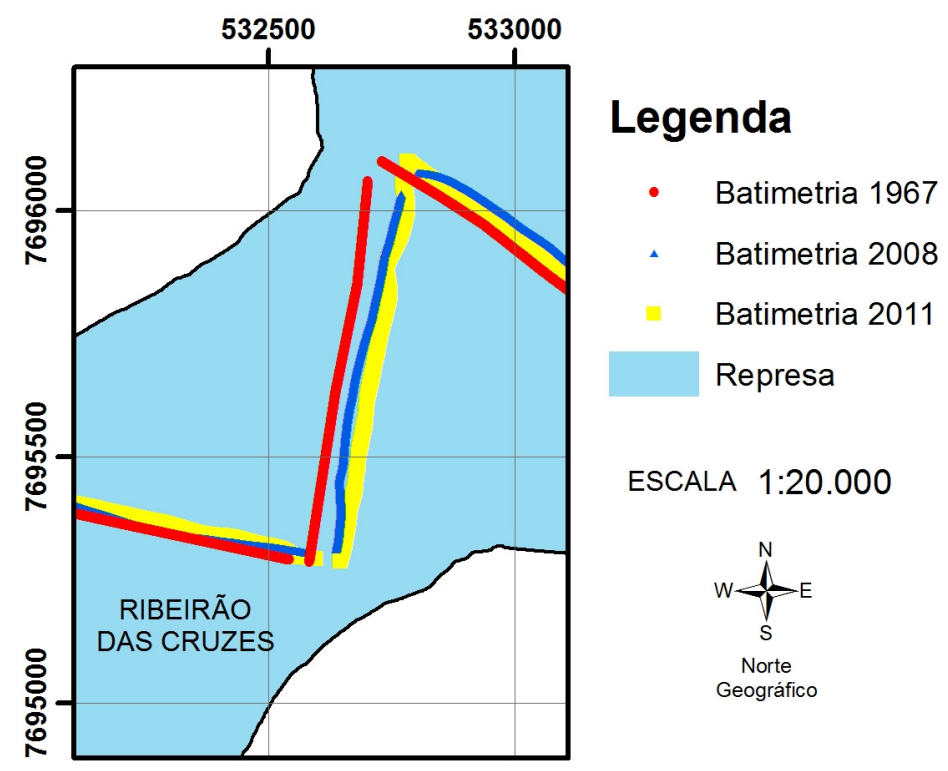

Figura 23. Exemplo dos traçados realizados pelo barco na coleta dos dados de batimetria. 


\subsubsection{Análise de consistência e tratamento de dados}

A Equação 6 foi utilizada para a correção da altimetria dos dados coletados.

$H=h+R-T$

Equação 6

onde:

$\mathrm{H}=$ altitude real do ponto

$\mathrm{h}=$ profundidade negativa coletada pela sonda

$\mathrm{R}=$ altura do nível d'água registrado na régua

$\mathrm{T}=$ profundidade do transdutor das ondas

Os dados referentes as informações da régua linimétrica e da profundidade do transdutor são apresentados na Tabela 7 em valores medidos às 12:00 pm de cada dia em que foram realizadas as campanhas batimétricas.

Tabela 7. Valores de leitura de régua e profundidade do transdutor nos dias de coleta de campo.

\begin{tabular}{ccc}
\hline Data & Leitura da régua $(\mathbf{m})$ & Profundidade do transdutor $(\mathbf{m})$ \\
\hline 25 de Março de 2008 & 328,07 & 0,40 \\
02 de Setembro de 2011 & 325,85 & 0,37 \\
\hline
\end{tabular}

\subsubsection{Cálculo do volume de assoreamento}

Os dados coletados e tratados e a delimitação do perímetro maxi maximorum da represa fornecem a base de dados necessários à formulação dos MDT's, que representam a topografia submersa do Ribeirão das Cruzes ao longo do tempo de existência da represa da UHE Três Irmãos. No entanto, o desvio lateral observado entre os dados das três batimetrias para cada transecto (Apêndice F), determina uma região de interpolação distinta para cada ano de análise. Ou seja, as áreas em planta provenientes dos MDT's resultantes de cada batimetria não foram perfeitamente sobrepostas, o que resultaria em dados incomparáveis do ponto de vista volumétrico. Desta forma, para efeito de comparação entre os modelos gerados, os resultados encontrados foram submetidos a um recorte de um espaço compatível com todos os dados gerados. A delimitação deste espaço foi determinada segunda a cota 328,4 metros, resultante do MDT da batimetria de 2011, que apresentou o único perímetro interno aos 
demais MDT's (Figura 24). Assim, os mapas topográficos que representam a região submersa da represa no Ribeirão das Cruzes para os dados originais contidos na carta do IGGSP (1967), para a "batimetria" de 1967, para a batimetria de 2008 e para a batimetria de 2011, são exemplificados na Figura 25 e apresentados por completo no Apêndice G, Apêndice H, Apêndice I e Apêndice J, respectivamente.

Para o cálculo do volume de assoreamento foi empregada a mesma metodologia utilizada no cálculo da erosão, no entanto, o plano superior que limita o cálculo foi estabelecido como sendo a cota maxi maximorum 328,4 metros. Assim, todo volume abaixo deste plano foi calculado com a ferramenta surface volume e os resultados estão na Tabela 8 , assim como os dados de área 2D e área 3D.

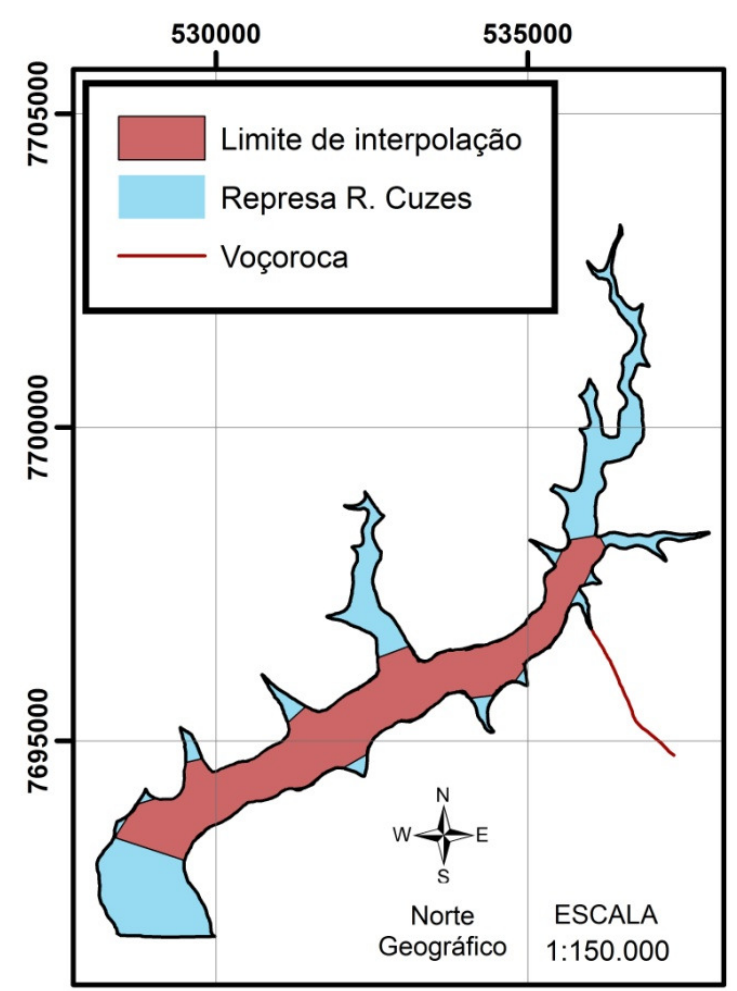

Figura 24. Limite da interpolação dos dados de batimetria.

Tabela 8. Resultados obtidos para os valores de área 2D, área 3D e volume para os MDT's da Carta IGGSP (1967) e das batimetrias de 1967, 2008 e 2011.

\begin{tabular}{ccccc}
\hline \multirow{2}{*}{ Parâmetros } & $\begin{array}{c}\text { Carta IGGSP } \\
\mathbf{1 9 6 7}\end{array}$ & $\begin{array}{c}\text { "Batimetria" } \\
\mathbf{1 9 6 7}\end{array}$ & $\begin{array}{c}\text { Batimetria } \\
\mathbf{2 0 0 8}\end{array}$ & $\begin{array}{c}\text { Batimetria } \\
\mathbf{2 0 1 1}\end{array}$ \\
\hline Data & Ano de 1967 & $01 / 08 / 1990$ & $25 / 03 / 2008$ & $09 / 09 / 2011$ \\
Área 2D $\left(\mathbf{m}^{2}\right)$ & 6.753 .290 & 6.753 .290 & 6.753 .297 & 6.753 .297 \\
Área 3D $\left(\mathbf{m}^{2}\right)$ & 6.761 .891 & 6.760 .411 & 6.766 .434 & 6.762 .677 \\
Volume $\left(\mathbf{m}^{3}\right)$ & 62.178 .094 & 51.116 .330 & 39.635 .559 & 38.807 .934 \\
\hline
\end{tabular}


As datas apresentadas na Tabela 8 informam os dias exatos em que foram realizados os estudos batimetricos de 2008 e 2011. A data estabelecida para a "batimetria" 1967, criada a partir das cartas do IGGSP (1967), foi fixado em 01 de agosto de 1990, mês e ano em que se iniciou o enchimento da represa da UHE Três Irmãos. Devido a falta de informações mais detalhadas do dia de início do enchimento, a escolha do primeiro dia do mês foi apenas de caráter complementar a fim de se considerar todo o mês nos cálculos de assoreamento.
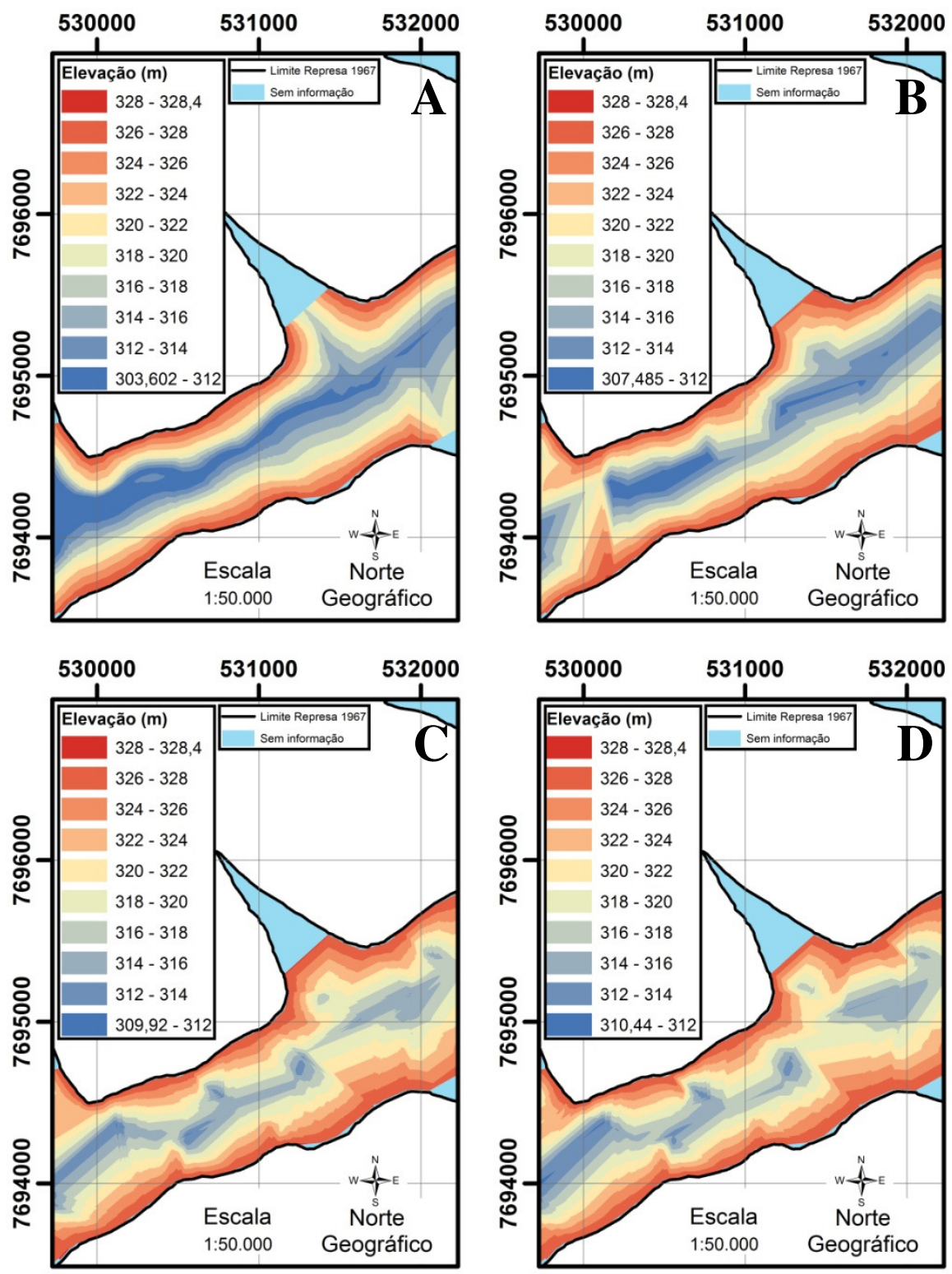

Figura 25. Exemplo da interpolação dos dados do IGGSP (A) e das batimetrias de 1967 (B), 2008 (C) e 2011 (D) para um trecho do Ribeirão das Cruzes. 
Para efeito dos cálculos de deposição de sedimento, foi desprezado o processo de assoreamento no Ribeirão das Cruzes, anterior ao enchimento da barragem, e a mutabilidade do terreno entre os anos de 1967 e 1990 . Ainda, supondo que não há mudanças significativas no regime de chuvas na região ao longo dos anos, entende-se que a vazão escoada pelo Ribeirão das Cruzes pouco se altera em relação à área transversal da calha do rio. Em condições naturais, anterior ao enchimento da barragem, a velocidade da água na área transversal ocupada pela calha original do ribeirão era maior do que na situação pós alagamento. Para comportar a mesma vazão em uma área maior de seção transversal, a velocidade da água diminui consideravelmente, alterando as condições de arrasto das partículas sólidas em suspensão, favorecendo sua deposição no leito do rio. Assim, o volume de material sólido depositado ao fundo do Ribeirão das Cruzes é consideravelmente maior no período posterior ao alagamento.

Em relação ao erro associado à determinação da topografia de fundo do reservatório apenas com transectos espaçados a cada $1,5 \mathrm{~km}$, foram comparados os volumes obtidos com os MDT's da caracterização do terreno segunda as cartas do IGGSP (1967) e da "batimetria" de 1967. A representação das curvas de nível originais em forma de transectos contendo pontos cotados com a mesma altimetria provocou uma diferença considerável entre os volumes que caracterizam o mesmo período da região analisada. Devendo ambos os volumes caracterizarem a mesma feição do terreno, estes apresentaram uma diferença de 11,06 hm $\left(11.061 .763 \mathrm{~m}^{3}\right)$ ou $17,79 \%$ quando comparados. Este erro é previsto uma vez que a inclusão de informações, no processo de interpolação para obtenção do MDT, por metodologias distintas, também resulta em informações distintas e incomparáveis entre si. Desta forma, o uso da mesma metodologia para aquisição dos dados nas três batimetrias em estudo, resulta em informações comparáveis do ponto de vista volumétrico, supondo o mesmo valor de erro entre o valor real e o valor obtido em cada levantamento.

Com estas considerações, foram estabelecidos dois períodos de análise do processo de assoreamento, além do período total. O primeiro período corresponde aos anos decorridos entre o início do enchimento da UHE Três Irmãos, agosto de 1990, e a batimetria realizada em março de 2008. O segundo período de estudo do processo de deposição dos sedimentos no leito do Ribeirão das Cruzes, aborda os anos decorridos entre as batimetrias de março de 2008 e setembro de 2011. Para o período completo foi considerado o período de agosto de 1990 e setembro de 2011 (Figura 26, APÊNDICE K, APÊNDICE L e APÊNDICE M). 


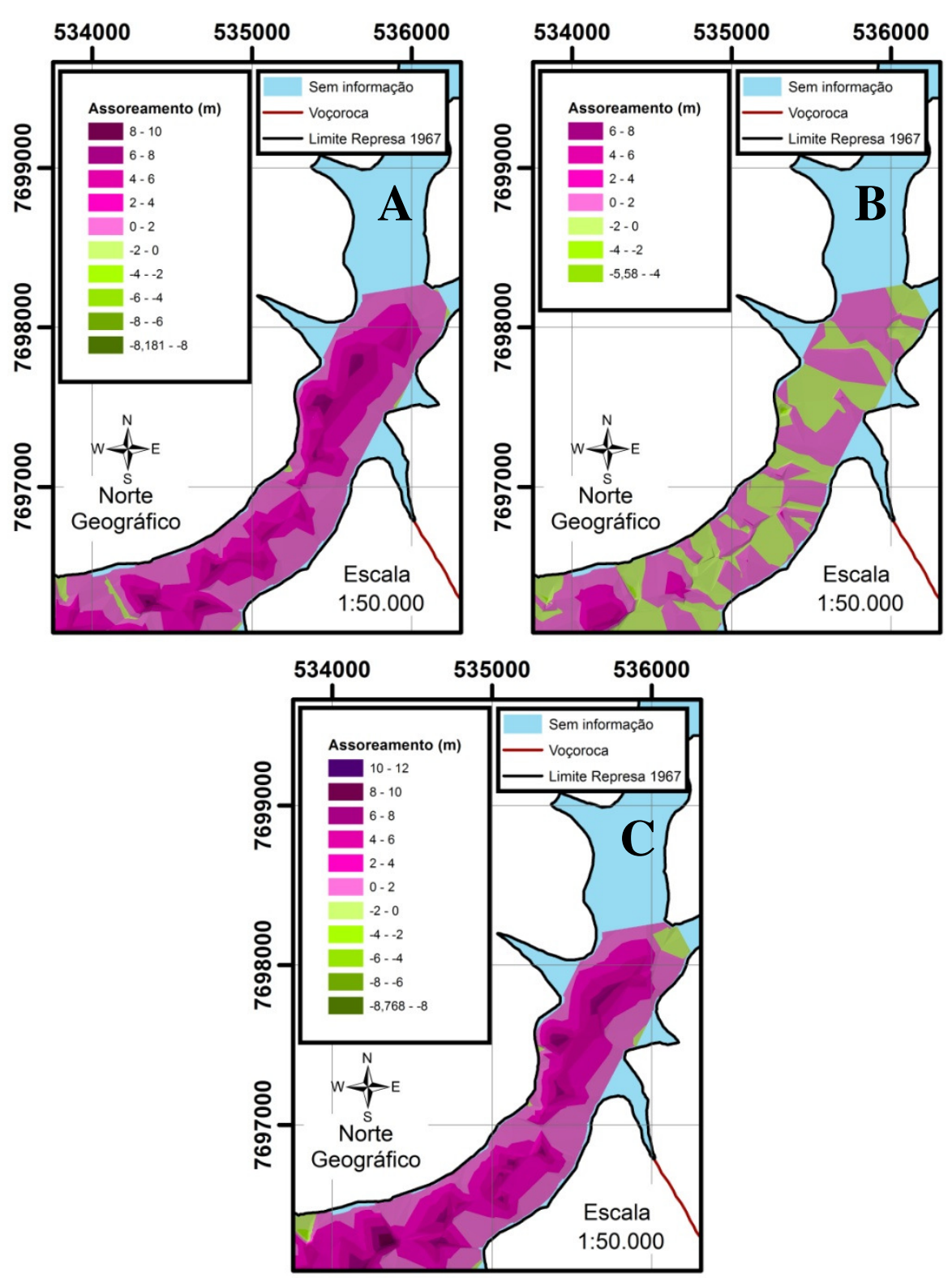

Figura 26. Exemplo do assoreamento e erosão no leito do Ribeirão das Cruzes para os períodos de 1967 à 2008 (A), 2008 à 2011 (B), e 1967 à 2011 (C).

De acordo com os dados obtidos pelo software ArcView 9.3 para os volumes dos MDT's da "batimetria" de 1967 (correspondente ao enchimento da represa em agosto de 1990) e da batimetria de 2008, foram computados em 17,66 anos de existência da represa, o assoreamento de, pelo menos, $11,48 \mathrm{hm}^{3}\left(11.480 .770 \mathrm{~m}^{3}\right)$. Cabe ressaltar que o termo "pelo menos" empregado na frase anterior, ressalva a existência dos 4 transectos de batimetria, a jusante do Ribeirão das Cruzes, que não foram analisados devido a inexistência de dados para a batimetria de 2011 e que, portanto, não há conhecimento do assoreamento nesta região. Assim, considerando apenas a área limitada para a interpolação dos dados nos MDT's, a deposição de sedimentos ocupou $22,46 \%$ do volume inicial da região analisada. A 
distribuição do assoreamento total pelos anos de análise remete a uma taxa média de deposição de sedimentos no Ribeirão das Cruzes de $1,27 \%$ ao ano, o que resultaria, na situação hipotética de considerar o Ribeirão das Cruzes como a represa total e não como um tributário, em 20,84 anos para sua vida útil ou seu assoreamento total, a partir de 25 de março de 2008 .

Posteriormente, para o segundo período de análise do assoreamento, os 3,46 anos decorridos entre as duas batimetrias realizadas pelo Núcleo de Hidrometria registraram a deposição de mais $0,83 \mathrm{hm}^{3}\left(827.625 \mathrm{~m}^{3}\right)$ de sedimento para a mesma região do leito do Ribeirão das Cruzes. Em relação ao volume encontrado para os dados da batimetria de 2008, o assoreamento ocupou 2,09\% do volume no período analisado. Nesta segunda fase do estudo da deposição de sedimentos, foi registrada a queda da taxa média de assoreamento para $0,6 \%$ ao ano, menos da metade do registrado no período anterior. Para a situação hipotética de assoreamento completo, a nova taxa de deposição prolongou a vida útil do reservatório para 53,19 anos, a partir de 09 de setembro de 2011.

Assim, o processo de assoreamento ocorrido nos 21,12 anos do período analisado de existência da represa no Ribeirão das Cruzes, ocupou o total de $12,31 \mathrm{hm}^{3}\left(12.308 .396 \mathrm{~m}^{3}\right)$ ou $24,08 \%$ do volume original, segundo as cartas do IGGSP (1967). A taxa média de deposição de sedimentos para todo o período analisado registrou 1,14\% ao ano, e vida útil hipotética de 21,83 anos, a partir de 09 de setembro de 2011, para o completo assoreamento do reservatório.

O registro da queda na taxa de assoreamento anual está relacionado aos agentes erosivos presentes na bacia hidrográfica. Sendo o Ribeirão das Cruzes a sua principal rede de drenagem e pelos conceitos aqui expostos, todo o material proveniente da ação da erosão hídrica na bacia hidrográfica influenciará diretamente nas condições hidrossedimentológicas deste corpo d'água.

Considerando os principais agentes desencadeadores dos processos erosivos em uma bacia hidrográfica, pode-se dizer que os únicos que influenciariam nos resultados obtidos para o período analisado seriam a erosividade da chuva e o uso e ocupação do solo. A erosividade da chuva depende de fatores de intensidade, duração e frequência, variáveis independentes do período de análise. Comumente em estudos hidrológicos, a fim de se minimizar a influência destas variáveis, é utilizada a média dos registros históricos de pelo menos 30 anos. Para o último período, por exemplo, os 3,46 anos decorridos entre os estudos de batimetria dificilmente representarão as condições de pluviosidade da bacia hidrográfica do Ribeirão das 
Cruzes. Neste curto espaço de tempo pode ter ocorrido chuvas de altas ou baixas intensidades, duração ou frequência, refletindo, para o primeiro caso, em elevada vazão e turbulência no curso d'água, revolvendo, resuspendendo e removendo o sedimento depositado, ou refletindo no baixo aporte de sedimentos aos rios, diminuindo o processo de deposição de sedimentos para o segundo caso de chuvas. Ainda neste período, entre 2009 e 2010, houve o registro da presença do El Niño com intensidade moderada, outro agravante que mascara as reais condições das chuvas em todo continente americano.

Neste caso de variação das condições das chuvas, a taxa de assoreamento registrada para todo o período de estudo, 21,12 anos seria a mais confiável do ponto de vista da média histórica, representando a real condição de assoreamento do Ribeirão das Cruzes.

Os registros históricos nos postos pluviométricos disponíveis no Sistema Integrado de Gerenciamento de Recursos Hídricos do estado de São Paulo, fornecem dados até Agosto de 2004, impossibilitando uma análise mais profunda com relação à erosividade das chuvas na região, principalmente para o curto período de análise entre 2008 e 2011.

O uso e ocupação do solo seria outro fator determinante nas condições de assoreamento do reservatório, podendo vir a explicar a variação observada na taxa de assoreamento. A análise adequada das mudanças ao longo dos anos para a classificação exige técnicas de sensoriamento remoto que forneçam imagens de alta resolução atuais e históricas, informações não adotadas no presente trabalho.

Os outros agentes erosivos, geomorfologia e erodibilidade do solo, por estarem associados à forma do relevo e ao tipo de solo, respectivamente, não representou influência na taxa de assoreamento para o período de estudo, uma vez que estes fatores apresentam alterações em suas naturezas apenas em longos períodos geológicos, com mais de milhares de anos para que sejam notadas as diferenças.

Outra explicação possível nas diferenças observadas nas taxas de assoreamento está nas condições de estabilidade das diversas voçorocas presentes na bacia hidrográfica. Se durante o período decorrido entre 2008 e 2011 muitas das voçorocas na área tivessem alcançado certo grau de estabilidade, o aporte de sedimentos oriundos deste tipo de erosão diminuiria consideravelmente, explicando a diferença entre os valores observados.

No entanto, é de se esperar que todas as explicações aqui elucidadas para a variação da taxa de sedimento, além de outros fatores, ocorram continuamente ao longo do período de análise, sendo, portanto, o resultado da soma de todas as influências que interferem na sedimentologia da bacia hidrográfica do Ribeirão das Cruzes. 
As médias de assoreamento anual do primeiro período de análise, 1990 a 2008, e para todo o período de análise, 1990 a 2011, se mostraram acima do registro médio mundial de $1 \%$ estimada em 1987 (MAHMOOD, 1987 apud CARVALHO, 2008). Em relação à média nacional, estimada em 0,5\% em 1992 (ELETROBRÁS/IPH, 1992 apud CARVALHO, 2008), todas as taxas dos períodos em análise superaram esta marca. Estas condições se explicam devido ao corpo d'água em estudo ser tributário da represa da UHE Três Irmãos. Assim, a influência dos depósitos de remanso e da interface rio/lago refletem, em grande parte, no interior do Ribeirão das Cruzes, descaracterizando as taxas de assoreamento em relação às médias nacional e mundial. Para o estudo de assoreamento da represa da UHE Três Irmãos realizado em 2008 por Costa (2009), mesmo dados utilizados na batimetria de 2008 do presente estudo, a taxa média foi registrada em $0,4 \%$ ao ano, demonstrando que o índice de deposição de sedimento ao longo de todo o reservatório está abaixo da média nacional.

A relação do volume de armazenagem do trecho do reservatório que compreende o Ribeirão das Cruzes pelo nível da água (Tabela 9), segundo os dados obtidos para o MDT das batimetrias, foram representados em gráfico (Figura 27), demonstrando a perda volumétrica no tributário para os períodos de análise.

Tabela 9. Distribuição do volume de água armazenado por cota segundo os MDT's das batimetrias de 1967, 2008 e 2011.

\begin{tabular}{cccccc}
\hline \multicolumn{7}{c}{ Volume $\left(\mathbf{h m}^{\mathbf{3}}\right)$} \\
\hline Cota $(\mathbf{m})$ & $\mathbf{1 9 6 7}$ & Cota $(\mathbf{m})$ & $\mathbf{2 0 0 8}$ & Cota $(\mathbf{m})$ & $\mathbf{2 0 1 1}$ \\
328,40 & 51,1163302 & 328,40 & 39,6355594 & 328,40 & 38,807934181 \\
328,00 & 48,4234424 & 328,00 & 36,9384549 & 328,00 & 36,106615166 \\
326,00 & 35,8673306 & 326,00 & 24,8827014 & 326,00 & 24,091113903 \\
324,00 & 25,2823994 & 324,00 & 15,5839753 & 324,00 & 14,967714765 \\
322,00 & 16,6487731 & 322,00 & 9,0196178 & 322,00 & 8,671078791 \\
320,00 & 10,0663220 & 320,00 & 4,6950435 & 320,00 & 4,519913108 \\
318,00 & 5,4700146 & 318,00 & 2,0850591 & 318,00 & 2,008566960 \\
316,00 & 2,6374078 & 316,00 & 0,7496182 & 316,00 & 0,705926146 \\
314,00 & 1,0918920 & 314,00 & 0,1865307 & 314,00 & 0,154448828 \\
312,00 & 0,3502442 & 312,00 & 0,0117754 & 312,00 & 0,004466305 \\
310,00 & 0,0575483 & 310,00 & 0,0000002 & 310,44 & 0,000000000 \\
308,00 & 0,0001058 & 309,92 & 0,0000000 & & \\
307,49 & 0,0000000 & & & & \\
\hline
\end{tabular}




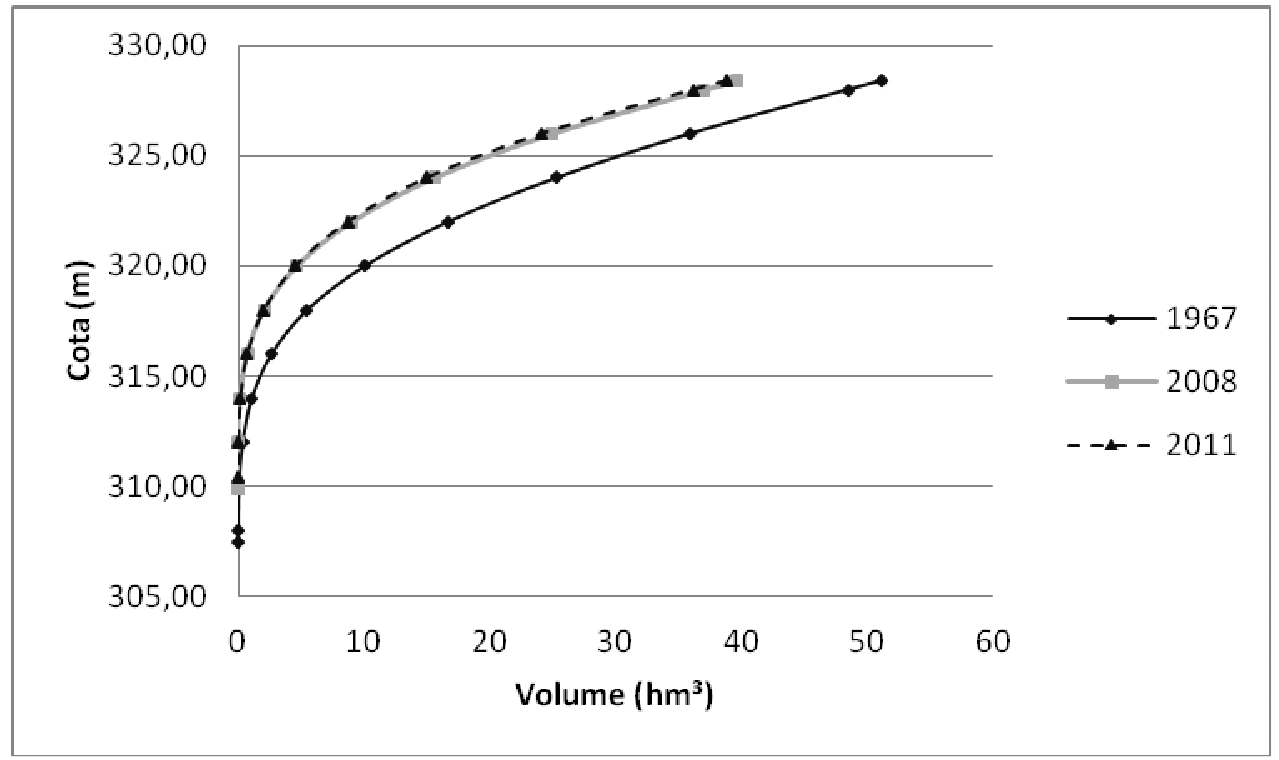

Figura 27. Curva COTA X VOLUME de 1967, 2008 e 2011 para o Ribeirão das Cruzes.

A dispersão cota $\mathrm{x}$ volume nos permite saber qual o volume armazenado de água em relação à altura do nível d'água. Esta ferramenta é de fundamental importância para o gerenciamento do uso da água, pois a quantificação do volume presente em determinados períodos fornece a base de dados necessária para a tomada de decisão quanto às necessidades prioritárias do uso.

\subsection{Contribuição da voçoroca para o assoreamento do Ribeirão das Cruzes}

A contribuição da erosão linear para o processo de assoreamento do Ribeirão das Cruzes foi estimada tomando por verdade a retenção de todo o sedimento desprendido da voçoroca dentro do corpo d'água. Assim, de uma forma global para toda a área estudada, a quantificação da contribuição da voçoroca partiu da comparação entre os volumes de material erodido e material depositado.

O volume de 0,22 $\mathrm{hm}^{3}$ estimado para a perda de solo na erosão representa, aproximadamente, $1,8 \%$ do volume de $12,31 \mathrm{hm}^{3}$ de material depositado no leito da represa entre os anos de 1990 e 2011. No entanto, considerando o período estimado de 7,11 anos de contribuição da voçoroca para o assoreamento, entre 01 de agosto de 2004 e 09 de setembro de 2011, e também considerando o volume estimado de assoreamento, proveniente de outras erosões para o mesmo período, através da distribuição média do assoreamento de $12,09 \mathrm{hm}^{3}$ (valor do assoreamento total menos o volume de $0,22 \mathrm{hm}^{3}$ da voçoroca) por ano de existência 
da represa (21,12 anos), o montante estimado de contribuição real da erosão linear em estudo para o assoreamento neste período é de $5,17 \%$.

Para um estudo mais refinado da ação dos sedimentos da voçoroca no interior do Ribeirão das Cruzes, o espaço amostral de material depositado foi subdividido em nove trechos de aproximadamente $1 \mathrm{Km}$ cada. Nos trechos, denominados por regiões na Figura 28, foram quantificadas as taxas de assoreamento individual com base na comparação entre os MDT's de cada batimetria.

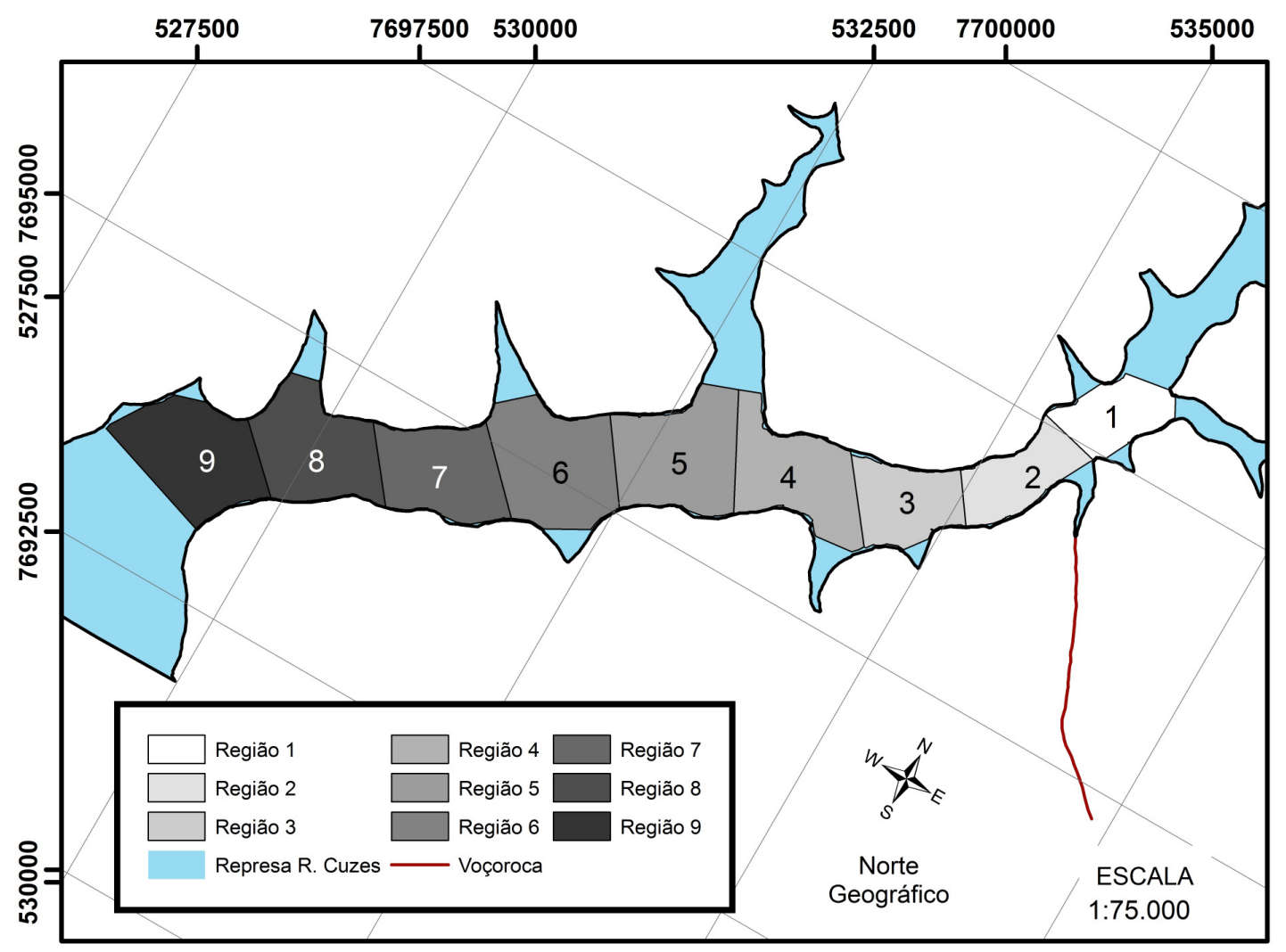

Figura 28. Regiões ou trechos de análise individual de taxas de assoreamento.

Os resultados obtidos para cada região e o período de análise estão apresentados na Tabela 10 e Figura 29. A subdivisão do Ribeirão das Cruzes em regiões distintas de análise demonstra claramente as principais áreas que sofreram com o depósito ou remoção de sedimentos, a partir da comparação dos volumes obtidos com as batimetrias. 
Tabela 10. Taxa de assoreamento por período e região.

\begin{tabular}{lccc}
\hline & \multicolumn{3}{c}{ Taxa de Assoreamento } \\
\hline Região 1 & $\mathbf{1 9 9 0}$ a 2008 & $\mathbf{2 0 0 8}$ a 2011 & $\mathbf{1 9 9 0}$ a 2011 \\
Região 2 & $2,60 \%$ & $0,22 \%$ & $2,19 \%$ \\
Região 3 & $2,11 \%$ & $1,51 \%$ & $1,92 \%$ \\
Região 4 & $2,08 \%$ & $1,42 \%$ & $1,89 \%$ \\
Região 5 & $1,51 \%$ & $0,40 \%$ & $1,31 \%$ \\
Região 6 & $1,13 \%$ & $-0,86 \%$ & $0,83 \%$ \\
Região 7 & $1,15 \%$ & $-0,15 \%$ & $0,94 \%$ \\
Região 8 & $0,65 \%$ & $0,59 \%$ & $0,63 \%$ \\
Região 9 & $0,48 \%$ & $-1,17 \%$ & $0,22 \%$ \\
\hline
\end{tabular}

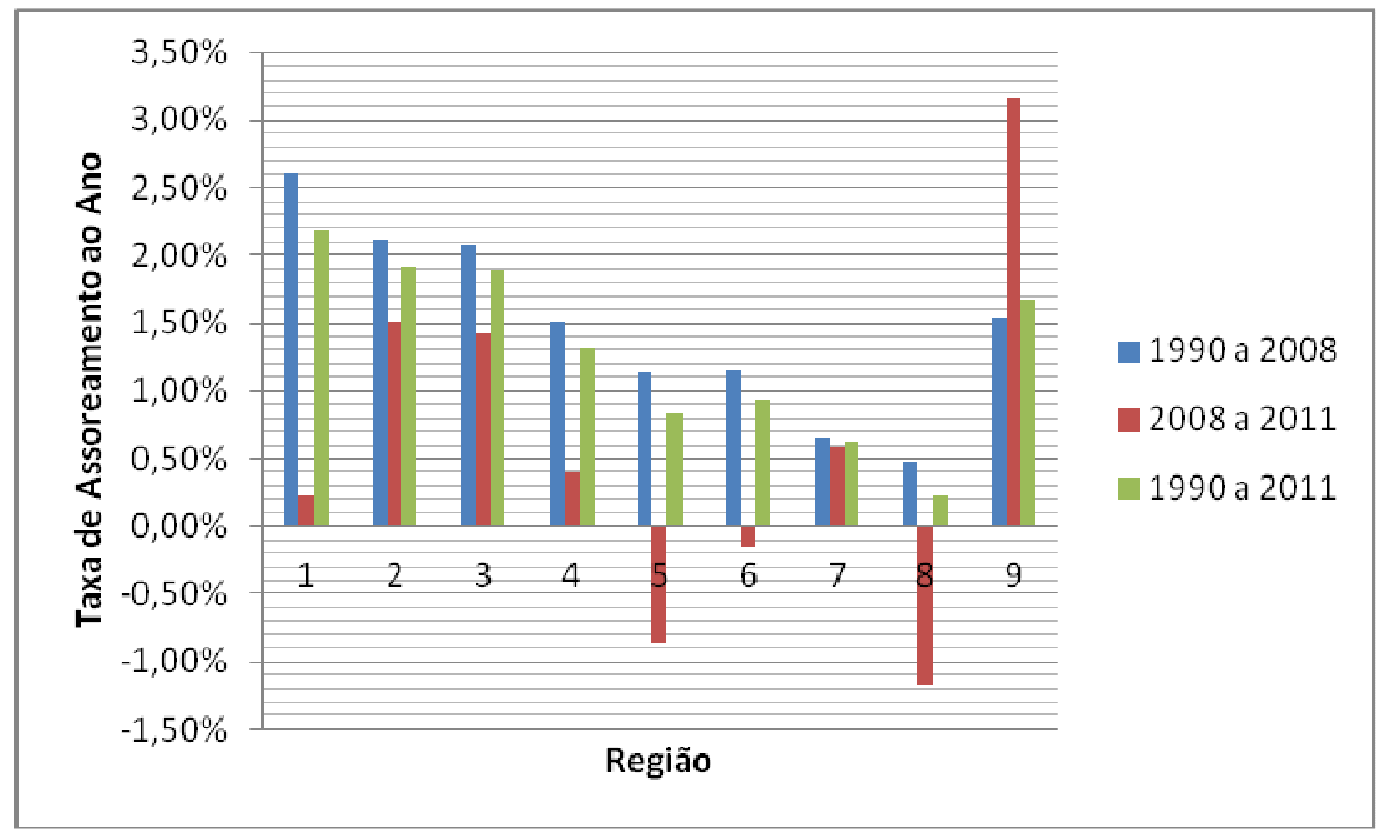

Figura 29. Taxa de assoreamento individual de cada região estipulada no Ribeirão das Cruzes.

Na região 1, trecho a montante do contato represa/voçoroca, houve uma elevada taxa de deposição de sedimentos no primeiro período de análise em comparação com o segundo. Esta região é a primeira a sofrer influências dos sedimentos da maior parte da bacia hidrográfica, por ser justamente o início da região de mudança brusca na velocidade de escoamento da água, interface rio/represa, e por concentrar grande parte de toda a vazão drenada na bacia. A baixa taxa registrada no segundo período pode estar associada ao regime de chuvas já comentado anteriormente, a adoção de práticas conservacionistas nas atividades agrícolas, como retenção de enxurradas com curvas de nível, ou mais provavelmente a 
elevação das velocidades de escoamento devido à diminuição da seção transversal da represa na área, provocada pelo assoreamento observado no período anterior, 45,84\% (Tabela 11).

Tabela 11. Assoreamento total por período e região

\begin{tabular}{lccc}
\hline & \multicolumn{3}{c}{ Assoreamento } \\
\hline Região 1 & $\mathbf{1 9 9 0}$ a 2008 & $\mathbf{2 0 0 8}$ a 2011 & $\mathbf{1 9 9 0}$ a 2011 \\
Região 2 & $45,84 \%$ & $0,76 \%$ & $46,26 \%$ \\
Região 3 & $37,30 \%$ & $5,23 \%$ & $40,58 \%$ \\
Região 4 & $36,74 \%$ & $4,93 \%$ & $39,86 \%$ \\
Região 5 & $26,68 \%$ & $1,40 \%$ & $27,70 \%$ \\
Região 6 & $19,98 \%$ & $-3,00 \%$ & $17,58 \%$ \\
Região 7 & $20,33 \%$ & $-0,52 \%$ & $19,91 \%$ \\
Região 8 & $11,49 \%$ & $2,05 \%$ & $13,30 \%$ \\
Região 9 & $8,45 \%$ & $-4,07 \%$ & $4,72 \%$ \\
\hline
\end{tabular}

Para a segunda região a qual recebe o afluente proveniente da voçoroca, as taxas para ambos os períodos permaneceram altas, registrando a grande influência que a região vem sofrendo com o processo de deposição. Da mesma forma, a região 3 mantêm, praticamente, as mesmas taxas observadas na região 2 , caracterizando uma "pluma" de sedimentos de aproximadamente $2 \mathrm{Km}$ de extensão. As taxas elevadas para ambas as regiões podem ser explicadas pelo avanço do assoreamento observado na região 1, confirmando a hipótese do aumento da velocidade da água na seção transversal e consequente deslocamento dos sedimentos para jusante, somado a influência exercida pelo material desprendido na voçoroca. Esta tendência permanece ainda na região 4, no entanto em menor intensidade.

A regiões 5 e 6 passaram por um processo de erosão de seus leitos, registrando taxas negativas de $-0,86 \%$ e $-0,15 \%$. Por estarem a jusante de uma intersecção do Ribeirão das Cruzes com um afluente de grande porte, há a possibilidade de uma eventual chuva de grande intensidade ter aumentado drasticamente a vazão do rio afluente, provocando o revolvimento do material depositado ao fundo, deslocando a massa de sedimentos para a região 7 ou até mesmo para a região 9 ou além. Da mesma forma, a região 8 pode ter sofrido com o mesmo evento, uma vez que também apresenta a união do Ribeirão com um novo afluente. 


\section{CONCLUSÃO}

.Com o intuito de se desenvolver uma pesquisa investigativa sobre a contribuição de uma voçoroca ao agravamento da situação de assoreamento em reservatórios, este trabalho buscou demonstrar o potencial da erosão em sulco quanto ao aporte de sedimentos aos corpos d'água. Dados reais coletados em campo e análises com auxílio de geoprocessamento reafirmaram as conclusões teóricas expostas por outros autores da área, de que estes tipos de erosão não devem ser desconsiderados em cálculos e estudos de aporte de sedimentos aos corpos d'água superficiais. Assim, foi possível verificar o problema e o comportamento do assoreamento no Ribeirão das Cruzes associado a este tipo de erosão linear, constatando que os estudos sedimentológicos e os levantamentos topográficos e batimétricos são de relevante importância para o planejamento e gerenciamento de reservatórios.

O levantamento topográfico permitiu a quantificação das características de dimensão e volume da voçoroca e do terreno no seu entorno, permitindo uma análise mais consistente do ponto de vista da engenharia de sedimentos com dados reais e inéditos da área de estudo. Assim, pode-se ter uma avaliação mais precisa na quantificação do sedimento originado da erosão e carreado para dentro do reservatório. Neste trabalho, foi demonstrado que o volume de material desprendido pela erosão linear em estudo foi da ordem de $0,22 \mathrm{hm}^{3}$, calculado a partir do MDT gerado pelo software de geoprocessamento Arcview 9.3.

Da mesma forma, os levantamentos batimétricos permitiram uma análise minuciosa do volume e do comportamento do assoreamento dentro do Ribeirão das Cruzes ao longo de dois períodos de análise, de agosto de 1990 a março de 2008 e de março de 2008 a setembro de 2011, demonstrando a evolução do processo de deposição e a variação das taxas de sedimentação ao longo do canal.

Para os primeiros 17,66 anos de análise, os levantamentos batimétricos demonstraram o assoreamento de $11,48 \mathrm{hm}^{3}$ do interior do reservatório, o que resultou em uma taxa de assoreamento de 1,27\% ao ano. Para os 3,46 anos restantes, correspondentes ao período de 2008 a 2011, a comparação entre os levantamentos demonstraram a diminuição do processo de assoreamento, registrando a perda volumétrica do reservatório em mais $0,83 \mathrm{hm}^{3}$, correspondente a uma taxa anual de assoreamento de 0,60\%. Em termos gerais, para os 21,12 anos decorridos entre o enchimento de reservatório e o levantamento batimétrico realizado em 09 de setembro de 2011, o Ribeirão das Cruzes reduziu a sua capacidade de armazenamento de água em 12,31 $\mathrm{hm}^{3}$, a uma taxa média de assoreamento de 1,14\% ao ano. 
A comparação entre o volume de material erodido e o volume de material depositado, quantificados com técnicas de mensuração direta, aponta a contribuição de $1,80 \%$ da voçoroca para o processo de assoreamento do Ribeirão das Cruzes, se considerado todo o período de análise. No entanto, o surgimento da erosão se deu posteriormente, mas precisamente a partir de agosto de 2004, o que em 7,11 anos de existência resultou na contribuição real de $5,17 \%$ para o assoreamento.

Em análise mais detalhada da influência da erosão no processo de deposição, os MDT's gerados com as informações dos levantamentos batimétricos foram subdivididos em 9 partes, com aproximadamente $1 \mathrm{Km}$ de extensão cada, para quantificação das taxas de assoreamento por região. Os resultados mostraram elevadas taxas de deposição nos $2 \mathrm{Km}$ que se seguem a jusante da interface reservatório/voçoroca, com possível causa associada ao lançamento dos sedimentos da erosão em estudo.

Assim, a intenção desta pesquisa foi apresentar, discutir e incentivar os estudos nesta área de conhecimento, apresentando as dificuldades encontradas pelos gestores de assoreamento de usinas hidrelétricas, na determinação do aporte de sedimentos aos reservatórios. Sendo o Brasil um país que apresenta uma matriz energética baseada em fontes hidráulicas, estudos que corroboram para um planejamento conservacionista dos reservatórios nacionais são muito importantes para o prolongamento da vida útil de operação das usinas e construção de novas unidades. 


\section{REFERÊNCIAS BIBLIOGRÁFICAS}

ALCÂNTARA, E.; NOVO, E.; STECH, J.; ASSIREU, A.; NASCIMENTO, R.; LORENZZETTI, J.; SOUZA, A. Integrating historical topographic maps and SRTM data to derive the bathymetry of a tropical reservoir. Journal of Hydrology, Ed. 389, p. 311-316, 2010 .

ARAUJO, Thiago Peixoto. Estudo do desencadeamento das erosões lineares concentradas em uma área do município de São Pedro/ SP. 2011. 181 f. Dissertação (Mestrado em Ciências) - Escola de Engenharia de São Carlos, Universidade de São Paulo, São Carlos, 2011.

ASSOCIAÇÃO BRASILEIRA DE NORMAS TÉCNICAS. NBR 13.133: Execução de levantamento topográfico. Rio de Janeiro, 1994, 35 p.

BERMANN, C. Impasses e controvérsias da hidroeletricidade. Estudos Avançados, Ed. 21, p. 139 - 153, 2007.

BERTONI, J.; NETO, F. L. Conservação do solo. São Paulo: Ícone, 6ª Ed., 2008. 355 p.

BLOOM, A. L. Erosão e transportes glaciais. In: Superfície da Terra. São Paulo: Edgard Blücher, 1970. p. 164 - 168.

BOUAZIZ, M.; LEIDIG, M.; GLOAGUEN, R. Optimal parameter selection for qualitative regional erosion risk monitoring: A remote sensing study of SE Ethiopia. Geosciences Frontiers, Ed. 2(2), p. 237 - 245, 2011.

BOUAZIZ, M.; WIJAYA, A.; GLOAGUEN, R. Gully erosion mapping using ASTER data and drainage network analysis in the main ethiopian rift. In: GEOSCIENCE AND REMOTE SENSING SYMPOSIUM, 2009, Cape Town. Anais... South Africa: Institute of Electrical and Electronics Engineers IEEE, 2009. p. I-13 - I-16.

BOUCHNAK, H.; FELFOUL, M. S.; BOUSSEMA, M. R.; SNANE, M. H. Slope and rainfall effects on the volume of sediment yield by gully erosion in the Souar lithologic formation (Tunisia). Catena, Ed. 78, p. 170 - 177, 2009.

BRASIL. Constituição da República Federativa do Brasil. Brasília, 1988. Diário Oficial.

BRASIL. Lei $\mathrm{n}^{\circ}$ 9433, de 8 de Janeiro de 1997. Institui a Política Nacional de Recursos Hídricos, cria o Sistema Nacional de Gerenciamento de Recursos Hídricos, regulamenta o inciso XIX do art. 21 da Constituição Federal, e altera o art. $1^{\circ}$ da Lei $n^{\circ} 8.001$, de 13 de março de 1990, que modificou a Lei $\mathrm{n}^{\circ}$ 7.990, de 28 de dezembro de 1989. Diário oficial da união, Brasília, 9 de janeiro de 1997. Disponível em: <http://www.planalto.gov.br/ccivil_03/leis/L9433.htm>. Acesso em: 07 mar. 2012.

BRAYSHAW, D.; HASSAN, M. A. Debris flow initiation and sediment recharge in gullies. Geomorphology, Ed. 109, p. 122 - 131, 2009.

CANIL, K.; IWASA, O. Y.; SILVA, W. S.; ALMEIDA, L. E. G. Mapa de feições erosivas lineares do estado de São Paulo: Uma análise qualitativa e quantitativa. In: SIMPÓSIO 
NACIONAL DE CONTROLE DE EROSÃO, 5. Bauru. Anais... São Paulo: Associação Brasileira de Geologia de Engenharia, 1995. V5, p. 249 - 251.

CARVAlHO, J. C.; SAlES, M. M.; MORTARI, D.; FÁZIO, J. A.; MOTTA, N. O.; FRANCISCO, R. A. Processos Erosivos. In: CARVALHO, J. C.; SALES, M. M.; SOUZA, N. M.; MELO, M. T. S. Processos erosivos no Centro-Oeste Brasileiro. Universidade de Brasília: FINATEC, 2006. p. 39 - 91.

CARVALHO, N. O. Hidrossedimentologia prática. Rio de Janeiro: Interciência, $2^{\mathrm{a}}$ Ed, 2008. 599 p.

CARVALHO, N. O.; LÔU, W. C. Avaliação da vida útil do reservatório da barragem no Rio Manso no Estado do Mato Grosso. Revista Brasileira de Engenharia, Caderno de grandes barragens, v. 1 (2), p. 61 - 70.

CASALÍ, J.; LOIZU, J.; CAMPO, M. A.; DE SANTISTEBAN, L. M.; ÁLVAREZ-MOZOS, J. Accuracy of methods for field assessment of rill and ephemeral gully erosion. Catena, Ed. 67, p. 128 - 138, 2006.

CASASNOVA, J. A. M. A spatial information technology approach for the mapping and quantification of gully erosion. Catena, Ed. 50, p. 293 - 308, 2003.

CENTRO TECNOLÓGICO DA FUNDAÇÃO PAULISTA DE TECNOLOGIA E EDUCAÇÃO - CETEC. Plano de Bacia do Baixo Tietê 2008. São Paulo, 2008. 282 p. (Relatório Final)

CHETTRI, R.; BOWONDER, B. Siltation on Nizamsagar reservoir: environmental management issues. Applied Geography, Ed. 3, p. 193 - 204, 1983.

COSTA, Ivo Gilberto Duarte David da. Análise do assoreamento no Reservatório de Três Irmãos - SP, utilizando dados topobatimétricos, hidrológicos e técnicas de geoprocessamento. 2009. 135 f. Dissertação (Mestrado em Ciências da Engenharia Ambiental) - Escola de Engenharia de São Carlos, Universidade de São Paulo, São Carlos, 2009.

DAEE. Plano Estadual de Recursos Hídricos: primeiro plano do Estado de São Paulo. São Paulo, DAEE, 1990.

DAEE. Relatório da situação dos recursos hídricos do estado de São Paulo. São Paulo, DAEE, 1999. 128p.

DAEE. Plano Estadual de Recursos Hídricos 2004 - 2007. São Paulo, DAEE, 2006. 92p.

DENDY, F. Sedimentation in the Nation's Reservoirs. Journal of Soil and Water Conservation, Ed. 23, p. 135 - 137, 1968.

DEPARTAMENTO DE ÁGUAS E ENERGIA ELÉTRICA; INSTITUTO DE PESQUISAS TECNOLÓGICAS (DAEE/IPT). Controle de erosão: Bases Conceituais e Técnicas Diretrizes para o Planejamento Urbano e Regional - Orientação para o controle de Boçorocas Urbanas. São Paulo, Ed. 2a , 1990. 92 p. 
DESCROIX, L.; GONZÁLEZ BARRIOS, J. L.; VIRAMONTES, D.; POULENARD, J.; ANAYA, E.; ESTEVES, M.; ESTRADA, J. Gully and sheet erosion on subtropical mountain slopes: Their respective roles and the scale effect. Catena, Ed. 72, p. 325 - 339, 2008.

FENG, L.; HU, C.; CHEN, X.; LI, R.; TIAN, L.; MURCH, B. MODIS observations of the bottom topography and its inter-annual variability of Poyang Lake. Remote Sensing of Environment, Ed. 115, p. 2729 - 2741, 2011.

FERREIRA, A. B.; SANTOS, C. R.; BRITO, J. L. S., ROSA, R. Análise comparativa do uso e ocupação do solo na área de influência da Usina Hidrelétrica Capim Branco I a partir de técnicas de geoprocessamento. In: SIMPÓSIO BRASILEIRO DE SENSORIAMENTO REMOTO, 12. Goiânia. Anais... Brasil: Instituto Nacional de Pesquisas Espaciais, 2005. p. 2997 - 3004.

FERREIRA, Marcilene Dantas. Análise da evolução dos processos erosivos acelerados em áreas urbanas e das técnicas de controle e recuperação: córrego do Tucum (São Pedro/SP). 2004. 171 f. Dissertação (Mestrado em Geotecnia) - Escola de Engenharia de São Carlos, Universidade de São Paulo, São Carlos, 2004.

FILL, H. D.; SANTOS, I. Estimativa da concentração de sedimentos em suspensão através da profundidade Sechi. In: SIMPÓSIO BRASILEIRO DE RECURSOS HÍDRICOS, 14, e SIMPÓSIO DE HIDRÁULICA E RECURSOS HÍDRICOS DE LÍNGUA OFICIAL PORTUGUESA, 5. Aracaju. Anais... Brasil: Associação Brasileira de Recursos Hídricos e Associação Portuguesa de Recursos Hídricos, 2001. p. 1 - 9.

FRANKL, A.; NYSSEN, J.; DAPPER, M.; HAILE, M.; BILLI, P.; MUNRO, R. N.; DECKERS, J.; POESEN, J. Linking long-term gully and river channel dynamics to environmental change using repeat photography (Northern Ethiopia). Geomorphology, Ed. 129, p. 238 - 251, 2011.

FUJIHARA, Alberto Kazutoshi. Predição de erosão e capacidade de uso do solo numa microbacia do Oeste Paulista com suporte em geoprocessamento. 2002. 136 f. Dissertação (Mestrado) - Escola Superior de Agricultura Luiz de Queiroz, Universidade de São Paulo, Piracicaba, 2002.

GEIßLER, C.; LANG, A. C.; OHEIMB, G.; HÄRDTLE, W.; BARUFFOL, M.; SCHOLTEN, T. Impact of tree saplings on the kinetic energy of rainfall-The importance of stand density, species identity and tree architecture in subtropical forests in China. Agricultural and Forest Meteorology, Ed. 156, p. 31 - 40, 2012.

GUERRA, A. J. T.; CUNHA, S. B. Geomorfologia: Uma atualização de bases e conceitos. Rio de Janeiro: Bertrand Brasil, Ed. 4a , 2001. 472 p.

GUIMARÃES, L. J. R.; SANTOS, L. J. C. Levantamento das áreas potenciais à erosão laminar como suporte à detecção das áreas-fonte ao assoreamento na barragem Piraquara I. Revista Eletrônica Geografar, v. 2, n. 2, 2007, p. 172 - 188. Disponível em: $<$ http://ojs.c3sl.ufpr.br/ojs2/index.php/geografar/article/viewFile/12106/8465> Acesso em: 07 mar. 2012.

GUOZHONG, W.; YADONG, M.; RUI, S.; JIANGANG, Q. Study On Depositing Process and Mechanism for Silt Dam in The West Mountains of Henan Province. In: IITA 
INTERNATIONAL CONFERENCE ON GEOSCIENCE AND REMOTE SENSING, 2. Qingdao. Anais... China: Institute of Electrical and Electronics Engineers IEEE , 2010. p. 121 $-124$.

HAREGEWEYN, N.; MELESSE, B.; TSUNEKAWA, A.; TSUBO, M.; MESHESHA, D.; BALANA, B. B. Reservoir sedimentation and its mitigating strategies: a case study of Angareb reservoir (NW Ethiopia). J Soils Sediments, Ed. 12, p. 291 - 305, 2012.

HENRIQUE, Cesar Sperchi. Regionalização hidrológica de vazões e de cargas difusas de sólidos suspensos totais para o programa ProdutorES de água e o pagamento de serviços ambientais: estudo de caso: bacia hidrográfica do Rio Benevente. 2009. 188 f. Dissertação (Mestrado) - Escola de Engenharia de São Carlos, Universidade de São Paulo, São Carlos, 2009.

HOFFMANN, C.; FUNK, R.; REICHE, M.; LI, Y. Assessment of extreme wind erosion and its impacts in Inner Mongolia, China. Aeolian Research, Ed. 3, p. 343 - 351, 2011.

HUA, F.; YANG, Y. Study on the erosion and deposition characteristics of Jiulongpo reach after the Three Gorges reservoir filling at 172m. In: GEOSCIENCE AND REMOTE SENSING SYMPOSIUM. Vancouver. Anais... Canadá: Institute of Electrical and Electronics Engineers IEEE, 2011.p. 1942 - 1945.

IDE, Daniela Massami. Investigação geotécnica e estudo de um processo erosivo causado por ocupação urbana. 2009. 129 f. Dissertação (Mestrado em Geotecnia) - Escola de Engenharia de São Carlos, Universidade de São Paulo, São Carlos, 2009.

INFANTI JUNIOR, N.; FORNASARI FILHO, N. Processos de Dinâmica Superficial. In: GEOLOGIA DE ENGENHARIA. São Paulo: Associação Brasileira de Geologia de Engenharia, 1998. p. 131 - 152.

INSTITUTO GEOGRÁFICO E GEOLÓGICO DO ESTADO DE SÃO PAULO (IGGSP). Aracanguá (SP). SF-22-D-III-4. (Mapa Topográfico. 1:50.000). São Paulo. 1967a.

INSTITUTO GEOGRÁFICO E GEOLÓGICO DO ESTADO DE SÃO PAULO (IGGSP). Auriflama (SP). SF-22-X-A-IV-2. (Mapa Topográfico. 1:50.000). São Paulo. 1967b.

JENSEN, J. R. Sensoriamento Remoto do Ambiente: uma perspectiva em recursos terrestres. Tradutor: EPIPHANIO, J. C. N. Tradução da segunda edição. ed. São José dos Campos, SP: Parêntese, 2009.

JI, J.; KOKUTSE, N.; GENET, M.; FOURCAUD, T.; ZHANG, Z. Effect of spatial variation of tree root characteristics on slope stability. A case study on Black Locust (Robinia pseudoacacia) and Arborvitae (Platycladus orientalis) stands on the Loess Plateau, China. Catena, Ed. 92, p. 139 - 154, 2012.

KERTÉSZ, Á.; GERGELY, J. Gully erosion in Hungary, review and case study. Procedia Social and Behavioral Sciences, Ed. 19, p. 693 - 701, 2011.

KOLDING, J.; ZWIETEN, P. A. M. Relative lake level fluctuations and their influence on productivity and resilience in tropical lakes and reservoirs. Fisheries Research, Ed. 115 116, p. 99 - 109, 2012. 
KOMPANI-ZARE, M.; SOUFI, M.; HAMZEHZARGHANI, H.; DEHGHANI, M. The effect of some watershed, soil characteristics and morphometric factors on the relationship between the gully volume and length in Fars Province, Iran. Catena, Ed. 86, p. 150 - 159, 2011.

KONZ, N.; PRASUHN, V.; ALEWELL, C. On the measurement of alpine soil erosion. Catena, Ed. 91, p. 63 - 71, 2012.

KÖPPEN, W. Das geographisca System der Klimate. In: KÖPPEN, W.; GEIGER, G. Handbuch der Klimatologie. Gerb: Borntraeger. 1936. p. 1 - 44.

KRASA, J.; DOSTAL, T.; ROMPAEY, A. V.; VASKA, J.; VRANA, K. Reservoirs' siltation measurments and sediment transport assessment in the Czech Republic, the Vrchlice catchment study. Catena, Ed. 64, p. 348 - 362, 2005.

LAL, R. Soil erosion in the tropics: principles and management. New York: McGraw-Hill, 1990. $580 \mathrm{p}$.

LASTRAS, G.; CANALS, M.; AMBlAS, D.; LAVOIE, C.; CHURCH, I.; MOL, B. D.; DURAN, R.; CALAFAT, A. M.; HUGHES-CLARKE, J. E.; SMITH, C. J.; HEUSSNER, S. Understanding sediment dynamics of two large submarine valleys from seafloor data: Blanes and La Fonera canyons, northwestern Mediterranean Sea. Marine Geology, Ed. 280, p. 20 39, 2011.

LEGLEITER, C. J.; KINZEL, P. J.; OVERSTREET, B. T. Evaluating the potential for remote bathymetric mapping of a turbid, sand-bed river: 1. Field spectroscopy and radiative transfer modeling. Water Resource Research, Ed. 47, Article number W09531, 2011.

LI, X.; WEI, X. Soil erosion analysis of human influence on the controlled basin system of check dams in small watersheds of the Loess Plateau, China. Expert Systems with Applications. Ed. 38. 2011. 4228 - 4233.

LOUREIRO, Diego Dozzi Tezza. Métodos atuais e novas tecnologias para o monitoramento do transporte de sedimentos em rios: necessidade de dados e incertezas envolvidas. 2009. 91 f. Dissertação (Mestrado em Ciências da Engenharia Ambiental) Escola de Engenharia de São Carlos, Universidade de São Paulo, São Carlos, 2008.

LU, Y.; ZUO, L.; JI, R.; LIU, H. Deposition and erosion in the fluctuating backwater reach of the Three Gorges Project after upstream reservoir adjustment. International Journal of Sediment Research, Ed. 25, p. 64 - 80, 2010.

LUCENA, M. M. A.; COSTA, D. F. S.; SOUZA, L. A.; ROCHA, R. M. Contribuição ao estudo do crescimento urbano nas margens do reservatório Comissão (Jardim do Seridó / RN) e seus potenciais impactos no ambiente. In: CONGRESSO DE ECOLOGIA DO BRASIL, 8. Caxambu. Anais... Minas Gerais: Sociedade de Ecologia do Brasil, 2007. Disponível em: < http://www.seb-ecologia.org.br/viiiceb/pdf/1574.pdf>. Acesso em: 07 mar. 2012.

MA, Y.; FRIEDRICHS, C. T.; HARRYS, C. K.; WRIGHT, L. D. Deposition by seasonal wave- and current-supported sediment gravity flows interacting with spatially varying bathymetry: Waiapu shelf, New Zealand. Marine Geology, Ed. 275, p. 199 - 211, 2010. 
MAIA, A. G.; VILlELA, S. M. Análise do assoreamento do reservatório de Promissão através do modelo RESSASS. Ambiência Guarapuava, PR, v. 5, n. 2 p. 247 - 262, 2009.

MAIA, A. G.; VILLELA, S. M. Análise qualitativa do assoreamento do reservatório de Promissão (SP). Revista brasileira de recursos hídricos, v. 15, n. 1 p. 39 - 46, 2010.

MANSOR, M. T. C.; FERREIRA, L.; ROSTON, D. M.; TEIXEIRA FILHO, J. Parâmetro para avaliação do potencial de risco de erosão. In: SIMPÓSIO REGIONAL DE GEOPROCESSAMENTO E SENSORIAMENTO REMOTO, 1. Aracajú. Anais... Brasil: EMBRAPA, $2002 . \quad$ Disponível em: <http://www.cpatc.embrapa.br/labgeo/srgsr1/pdfs/poster12.PDF> Acesso em: 07 mar. 2012.

MARZOLFF, I.; POESEN, J. The potential of 3D gully monitoring with GIS using highresolution aerial photography and a digital photogrammetry system. Geomorphology, Ed. 111, p. $48-60,2009$.

MENDONÇA, A. S. Introdução: (Razões para a quantificação). In: Hidrologia aplicada à gestão de pequenas bacias hidrográficas / organizado por João Batista Dias de Paiva e Eloiza Maria Cauduro Dias de Paiva. - Reimpressão rev. aum. - Porto Alegre: ABRH, 2003. 32 p.

MIRANDA, Jocy Gonçalo de. Mapeamento geotécnico e estudo de susceptibilidade à erosão na bacia do Ribeirão Ponte de Pedra (MT), escala: 1:100.00. 2005. $278 \mathrm{f}$. Tese (Doutorado em Geotecnia) - Escola de Engenharia de São Carlos, Universidade de São Paulo, São Carlos, 2005.

MIRANDA, Renato Billia. A influência do assoreamento na geração de energia hidrelétrica: estudo de caso na usina hidrelétrica de Três Irmãos - SP. 2011. 132 f. Dissertação (Mestrado em Ciências da Engenharia Ambiental) - Escola de Engenharia de São Carlos, Universidade de São Paulo, São Carlos, 2011.

MORAIS, F.; BACELLAR, L. A. P.; SOBREIRA, F. G. Análise da erodibilidade de saprolitos de gnaisse. Revista Brasileira de Ciência do Solo, v. 28, n. 6, 2004. Disponível em: <http://www.scielo.br/pdf/rbcs/v28n6/22927.pdf>. Acesso em: 07 mar. 2012.

MORGAN, R. P. C. Soil erosion and conservation. Inglaterra: Longman Group, 1986. 289 p.

NDOMBA, P. M.; MTALO, F.; KILLINGTVEIT, A. Estimating gully erosion contribution to large catchment sediment yield rate in Tanzânia. Physics and Chemistry of the Earth, Ed. 34, p. 741-748, 2009.

ORPIN, A. R.; CARTER, L.; PAGE, M. J.; COCHRAN, U. A.; TRUSTRUM, N. A.; GOMEZ, B.; PALMER, A. S.; MILDENHALL, D. C.; ROGERS, K. M.; BRACKLEY, H. L.; NORTHCOTE, L. Holocene sedimentary record from Lake Tutira: A template for upland watershed erosion proximal to the Waipaoa Sedimentary System, northeastern New Zealand. Marine Geology, Ed. 270, p. 11 - 29, 2010.

PAZ, V. P. S.; TEODORO, R. E. F.; MENDONÇA, F. C. Recursos hídricos, agricultura irrigada e meio ambiente. Revista Brasileira de Engenharia Agrícola e Ambiental, Campina Grande, v.4, n.3, p. 465 - 473, 2000. 
PFENNIGBAUER, M.; ULLRICH, A.; STEINBACHER, F.; AUFLEGER, M. Highresolution hydrographic airborne laser scanner for surveying inland waters and shallow coastal zones. Proceedings of SPIE - The International Society for Optical Engineering, Ed. 8037, Article number 803706, 2011. Disponível em: $<$ http://spiedigitallibrary.org/proceedings/resource/2/psisdg/8037/1/803706_1?isAuthorized=n o>. Acesso em: 07 mar. 2012.

POÇANO, W. L.; PRANDINI, F. L. Boçorocas no estado de São Paulo: Uma revisão. In: Simpósio Nacional de Controle de Erosão, 4. Marília. Anais... São Paulo: 1987,p. 149 - 175.

POESEN, J., NACHTERGAELE, J., VERSTRAETEN, G., VALENTIN, C. Gully erosion and environmental change: importance and research needs. Catena, Ed. 50, p. 91-133, 2003.

PORTO, M. F. A.; PORTO, R. L. L. Gestão de Bacias Hidrográficas. Estudos avançados, v. 22, n. 63, 2008. Disponível em: $<$ http://www.scielo.br/scielo.php?script=sci_arttext\&pid=S010340142008000200004\&Ing=en\&nrm=iso >. Acesso em: 26 fev. 2012.

RAMSAY, T.; PYSKLYWEC, R. Anomalous bathymetry, 3D edge driven convection, and dynamic topography at the western Atlantic passive margin. Journal of Geodynamics, Ed. 52, p. 45 - 56, 2011.

RATZOV, G.; COLlOT, J.; SOSSON, M.; MIGEON, S. Mass-transport deposits in the northern Ecuador subduction trench: Result of frontal erosion over multiple seismic cycles. Earth and Planetary Science Letters, Ed. 296, p. 89 - 102, 2010.

RIJSDIJK, A.; BRUIJNZEEL, L. A. S.; PRINS, T. M. Sediment yield from gullies, riparian mass wasting and bank erosion in the Upper Konto catchment, East Java, Indonesia. Geomorphology, Ed. 87, p. 38 - 52, 2007.

RYZHOV, Y. V. The erosion-accumulative processes within the basins of small rivers of southern East Siberia. Geography and Natural Resources, Ed. 30, p. 265 - 271, 2009.

SAMBUELLI, L.; BAVA, S. Case study: A GPR survey on a morainic lake in northern Italy for bathymetry, water volume and sediment characterization. Journal of Applied Geophysics. Ed. XX. 2011. XX - XX. Disponível em: $<$ http://www.sciencedirect.com/science/article/pii/S0926985111002084>. Acesso em: 07 mar. 2012.

SANTOS, R. F.; Planejamento ambiental: teoria e prática. São Paulo: Oficina de textos, 2004.

SANTOS, I.; FILL, H. D.; KISHI, R. T.; MARONE, E.; LAUTERT, L. F. Hidrometria Aplicada. Lactec, Curitiba, 2001, 372 p.

SAVINI, A.; CORSELLI, C. High-resolution bathymetry and acoustic geophysical data from Santa Maria di Leuca Cold Water Coral province (Northern Ionian Sea-Apulian continental slope). Deep-Sea Research II, Ed. 57, p. 326 - 344, 2010.

SIDORCHUK, A. Dynamic and static models of gully erosion. Catena, Ed. 37, p. 401 - 414. 1999. 
SILVA, Aristotelina Ferreira da. Mapeamento geotécnico e análise dos processos erosivos na bacia do córrego Tucum, São Pedro - SP. 2003. 131 f. Dissertação (Mestrado em Geotecnia) - Escola de Engenharia de São Carlos, Universidade de São Paulo, São Carlos, 2003.

SILVA, L. C. N.; FERNANDES, A. L. V.; OLIVEIRA, W. Análise do uso e ocupação do solo na microbacia Dom Tomaz no município de Três Lagoas - MS. In: Seminário de Recursos Hídricos da Bacia Hidrográfica do Paraíba do Sul, 1. Taubaté. Anais... São Paulo: Universidade de Taubaté; Instituto de pesquisas ambientais em bacias hidrográficas; Instituto Nacional de Pesquisas Espaciais, 2007. p. 325 - 330.

SILVIO, G.; DALL'ANGELLO, C.; BONALDO, D.; FASOLATO, G. Long-term model of planimetric and bathymetric evolution of a tidal lagoon. Continental Shelf Research, Ed. 30, p. 894 - 903, 2010.

SOBRAL, M. C. M.; CARVALHO, R. M. C. M. O.; SILVA, M. M.; MELO, G. L. Uso e ocupação do solo no entorno de reservatórios no semi-árido brasileiro como fator determinante da qualidade da água. In: CONGRESO INTERAMERICANO DE INGENIERÍA SANITARIA Y AMBIENTAL, 30. Punta del Este. Anais... Uruguay: Associação Interamericana de Engenharia Sanitária e Ambiental, 2006. Disponível em: <http://www.bvsde.paho.org/bvsaidis/uruguay30/BR08521_Sobral.pdf>. Acesso em: 07 mar. 2012.

SOUZA, C. F.; DORNELLES, A. M.; ACIOLI, L. A.; MERTEN, G. H. Comparação dentre estimativas de produção de sedimentos na bacia do rio Potiribu. In: ENCONTRO NACIONAL DE ENGENHARIA DE SEDIMENTOS, 7. Porto Alegre. Anais... Rio Grande do Sul: Associação Brasileira de Recursos Hídricos, 2006. Disponível em: <http://www.lume.ufrgs.br/bitstream/handle/10183/1299/000564486.pdf?sequence=1>. Acesso em: 07 mar. 2012.

STERNBERG, R. Damming the river: a changing perspective on altering nature. Renewable and Sustainable Energy Reviews, Ed. 10, p. 165 - 197, 2006.

SPERLING, E. V. Morfologia de lagos e represas. Belo Horizonte: DESA/UFMG, 1999. $138 \mathrm{p}$.

TEIXEIRA, Felipe Jorge. Avaliação do assoreamento do reservatório de Barra Bonita utilizando comparação de mapas batimétricos. 2008. 99 f. Dissertação (Mestrado em Ciências da Engenharia Ambiental) - Escola de Engenharia de São Carlos, Universidade de São Paulo, São Carlos, 2008.

TEIXEIRA, C.; TUNDISI, J. G. Primary production and phytoplankton in equatorial waters. Bulletin Of Marine Science, v. 17, n. 4, 1967. 884 - 891.

TEIXEIRA, C.; TUNDISI, J. G.; KUTNER, M. B. Plankton studies in a mangrove environment. II. The stading stock and some ecological factors. Boletim Institucional Oceanográfico. USP, São Paulo, v. 14, 1965. 13 - 42.

THORARINSDOTTIR, E. F.; ARNALDS, O. Wind erosion of volcanic materials in the Hekla area, South Iceland. Aeolian Research, Ed. 4, p. 39 - 50, 2012. 
THOTHONG, W.; HUON, S.; JANEAU, J.; BOONSANER, A.; ROUW, A.; PLANCHON, O.; BARDOUX, G.; PARKPIAN, P. Impact of land use change and rainfall on sediment and carbon accumulation in a water reservoir of North Thailand. Agriculture Ecosystems and Environment, Ed. 140, p. 521 - 533, 2011.

TORRI, D.; POESEN, J.; BORSELLI, L.; KNAPEN, A. Channel width-flow discharge relationships for rills and gullies. Geomorphology, Ed. 76, p. 273 - 279, 2006.

TUCCI, C. E. M. Hidrologia: ciência e aplicação. Porto Alegre: Editora da UFRGS / ABRH, Ed. $3^{\text {a }}$, 2002. 943 p.

TUNDISI, J. G. Produção primária, "standing-stock" e fracionamento de fitoplâncton na região Lagunar de Cananéia. Tese - Universidade de São Paulo, São Paulo. 1969. 131p.

VALÉRIO, A. M.; SILVA, G. B. S.; KAMPEL, M.; STECH, J. L.; ASSIREU, A. T. Mapa do uso do solo da bacia do reservatório do Manso para o ano de 2007. In: SIMPÓSIO NACIOMAL CERRADO, 9, e SIMPÓSIO INTERNACIONAL SAVANAS TROPICAIS, 2. Brasília. Anais... Brasil: EMBRAPA, 2008. Disponível em: <http://simposio.cpac.embrapa.br/> Acesso em: 07 mar. 2012.

VANMAERCKE, M.; POESEN, J.; VERSTRAETEN, G.; VENTE, J.; OCAKUGLU, F. Sediment yield in Europe: Spatial patterns and scale dependency. Geomorphology, Ed. 130, p. 142 - 161, 2011.

VESTENA, L. R.; LUCINI; KOBIYAMA, M. Monitoramento Automático da Concentração de Sedimentos em Suspensão na Bacia Hidrográfica do Caeté, Alfredo Wagner/SC. In: WORKSHOP REGIONAL DE GEOGRAFIA E MUDANÇAS AMBIENTAIS, 1. Guarapuava. Anais... Paraná: Unicentro, 2007, v. 1, p. 61-70.

VON SPERLING, E. Morfologia de Lagos e Represas. Belo Horizonte: Universidade Federal de Minas Gerais. 1999. 136 p.

VRIELING, A. Satellite remote sensing for water erosion assessment: A review. Catena, Ed. 65, p. 2 - 18, 2006.

WALTHER, S. C.; MARCUS, W. A.; FONSTAD, M. A. Evaluation of high-resolution, truecolour, aerial imagery for mapping bathymetry in a clear-water river without ground-based depth measurements. International Journal of Remote Sensing, Ed. 32, p. 4343 - 4363, 2011.

WANG, S.; YAN, Y.; LI, Y. Spatial and temporal variations of suspended sediment deposition in the alluvial reach of the upper Yellow River from 1952 to 2007. Catena, Ed. 92, p. $30-37,2012$.

WANG, Z.; HU, C. Strategies for managing reservoir sedimentation. International Journal of Sediment Research, Ed. 24, p. 369 - 384, 2009.

WIRTZ, S.; SEEGER, M.; RIES, J. B. Field experiments for understanding and quantification of rill erosion processes. Catena, Ed. 91, p. 21 - 34, 2012. 
WISHMEIER, W. H.; SMITH, D. D. Predicting rainfall erosion losses: a guide planning. Washington, D. C.: USDA, (Handbook, 537), 1978. 58 p.

YANG, S. L.; MILLIMAN, J. D.; LI, P. XU, K. 50,000 dams later: Erosion of the Yangtze River and its delta. Global and Planetary Change, Ed. 75, p. 14 - 20, 2011.

YOSHIKAWA, S.; NEMOTO, K. Seasonal variations of sediment transport to a canyon and coastal erosion along the Shimizu coast, Suruga Bay, Japan. Marine Geology, Ed. 271, p. $165-176,2010$.

ZACHAR, D. Soil erosion. Brastlava: Elsevier Scientific Public. Co, 1982. 547 p.

ZINCK, J. A.; LÓPEZ, J.; METTERNICHT, G. I.; SHRESTHA, D. P.; VÁZQUEZ-SELEM, L. Mapping and modeling mass movements and gullies in mountainous areas using remote sensing and GIS techniques. International Journal of Applied Earth Observation and Geoinformation, Ed. 3, p. 43 - 53, 2001. 
APÊNDICE A -

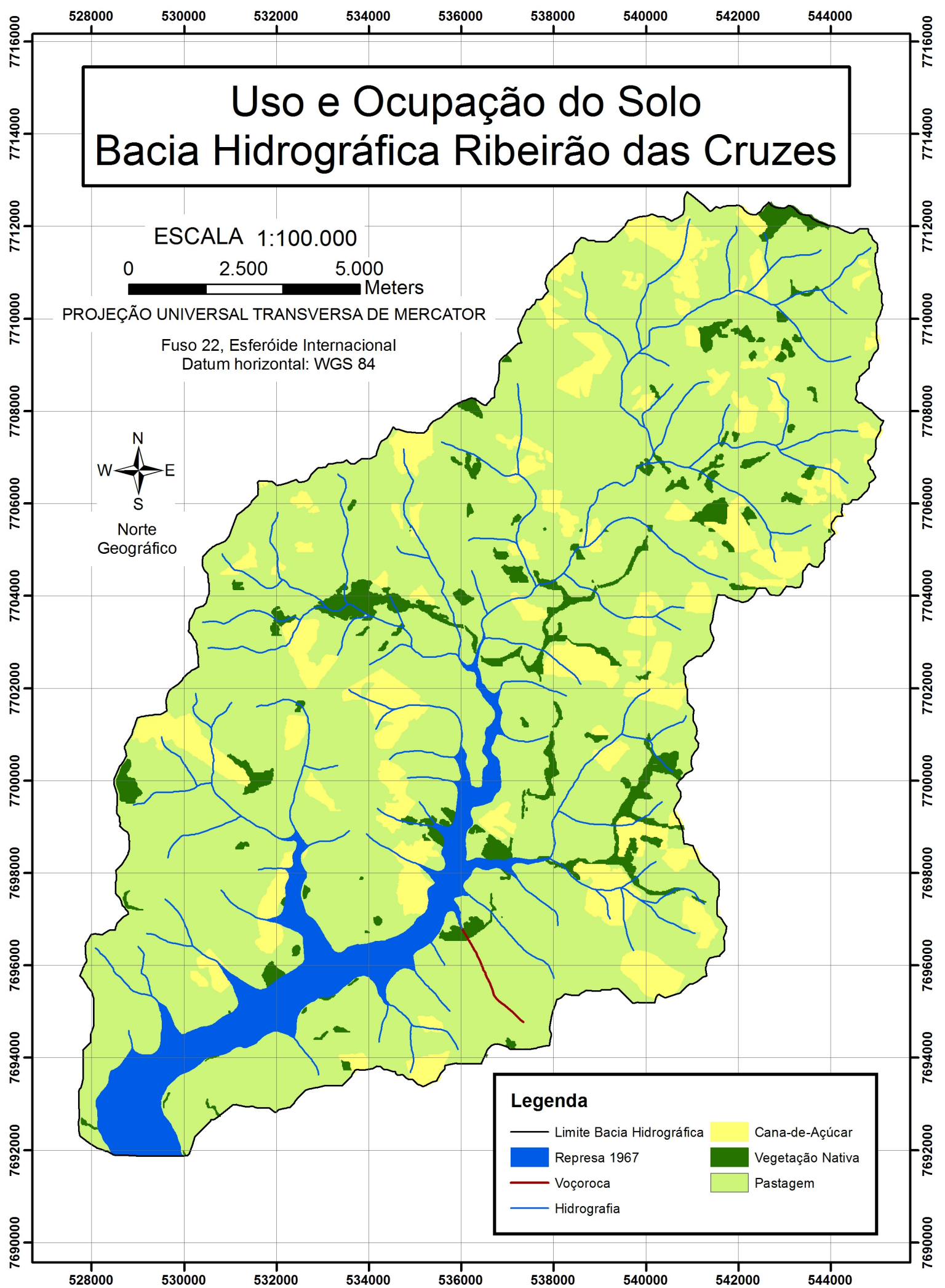


APÊNDICE B -

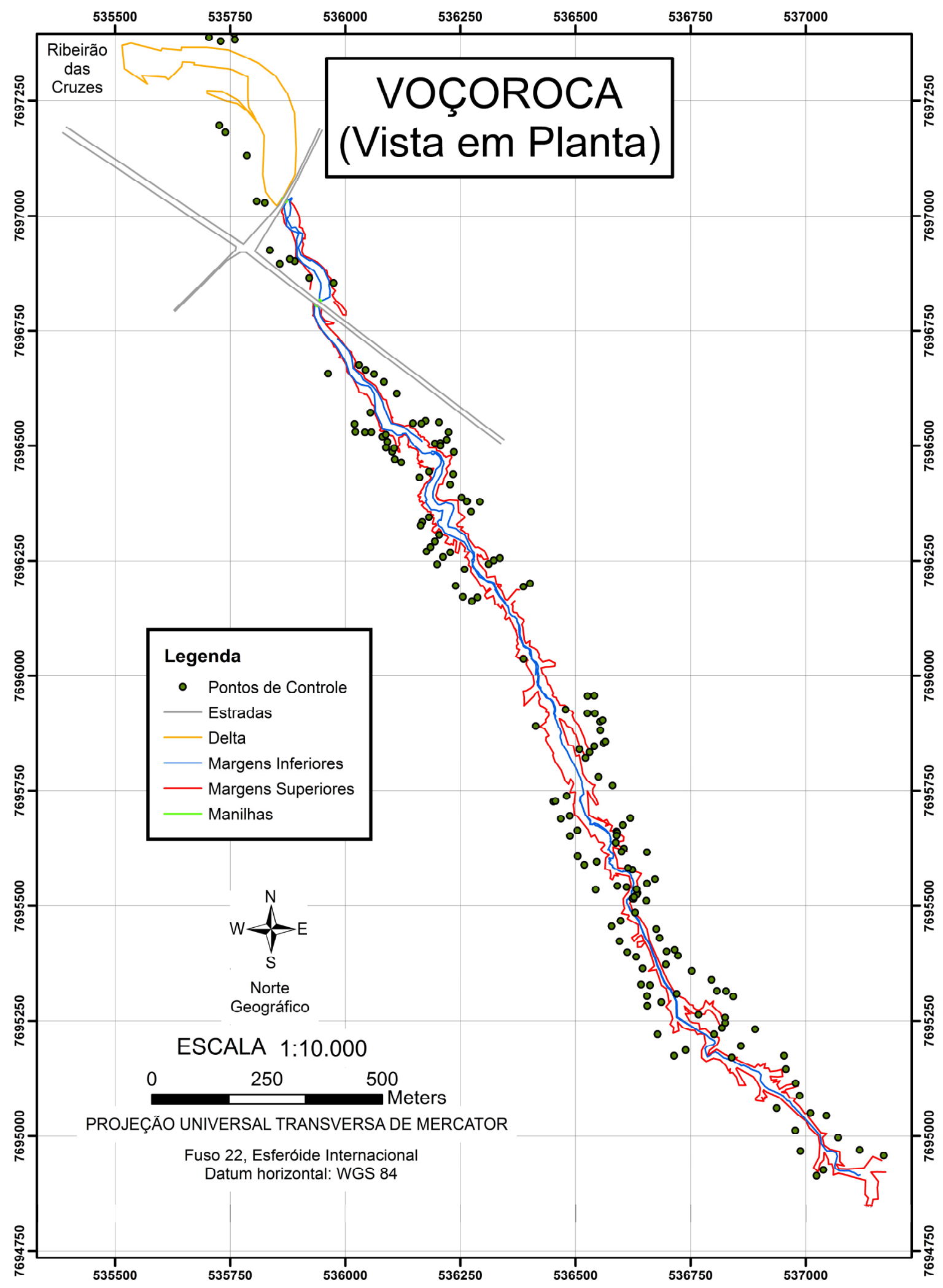


APÊNDICE C -

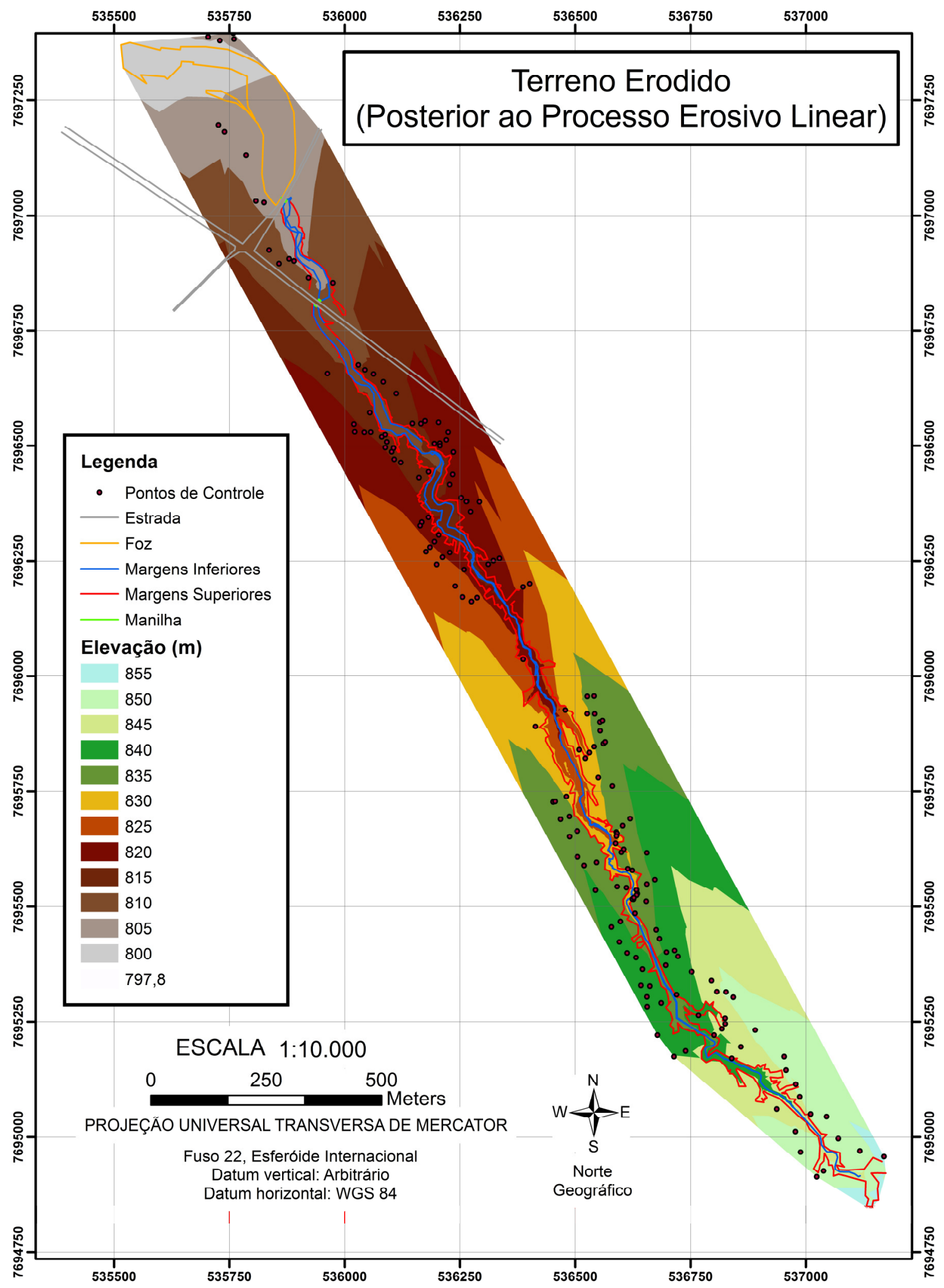


APÊNDICE D -

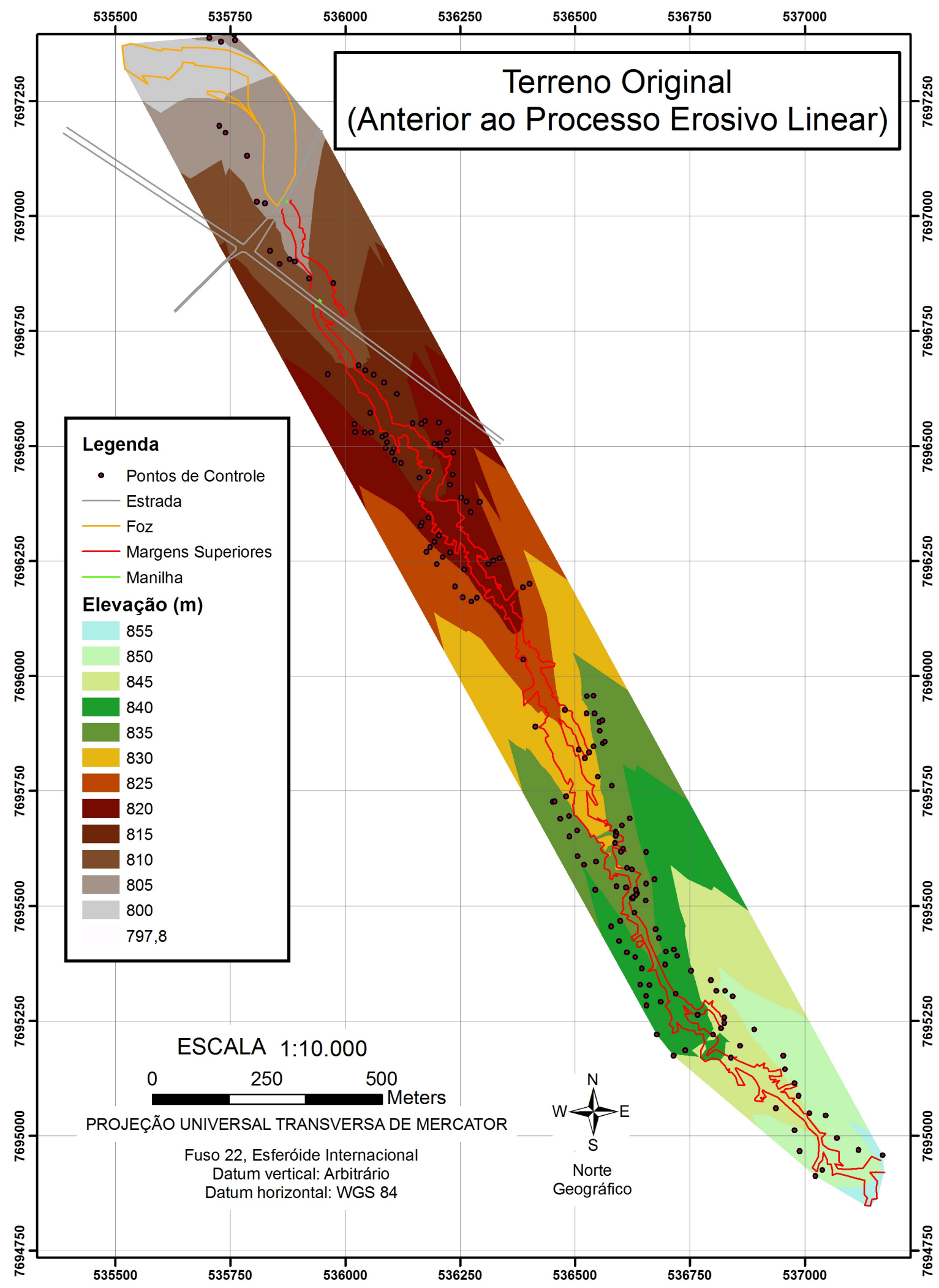


APÊNDICE E -

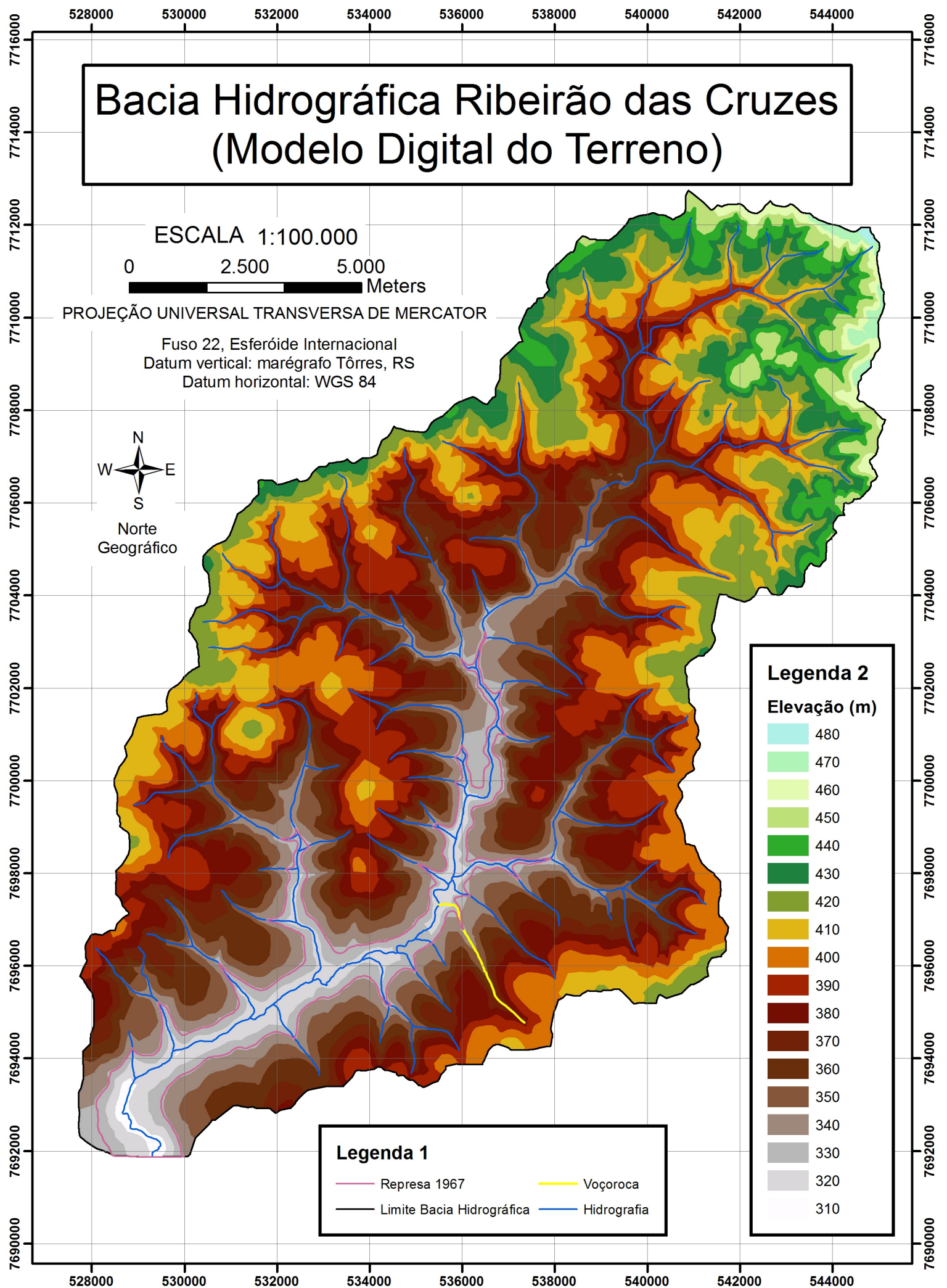


APÊNDICE F -

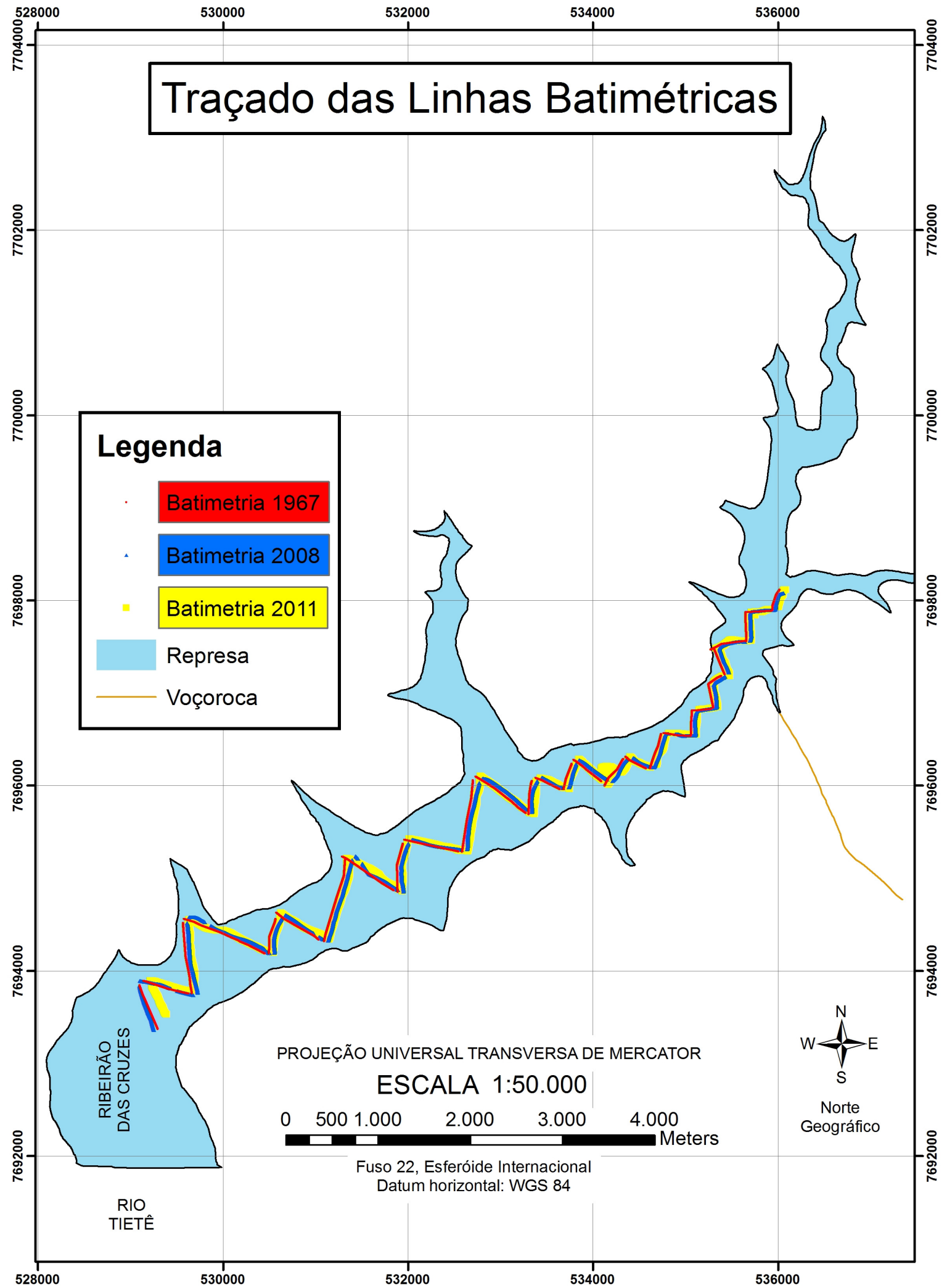


APÊNDICE G -

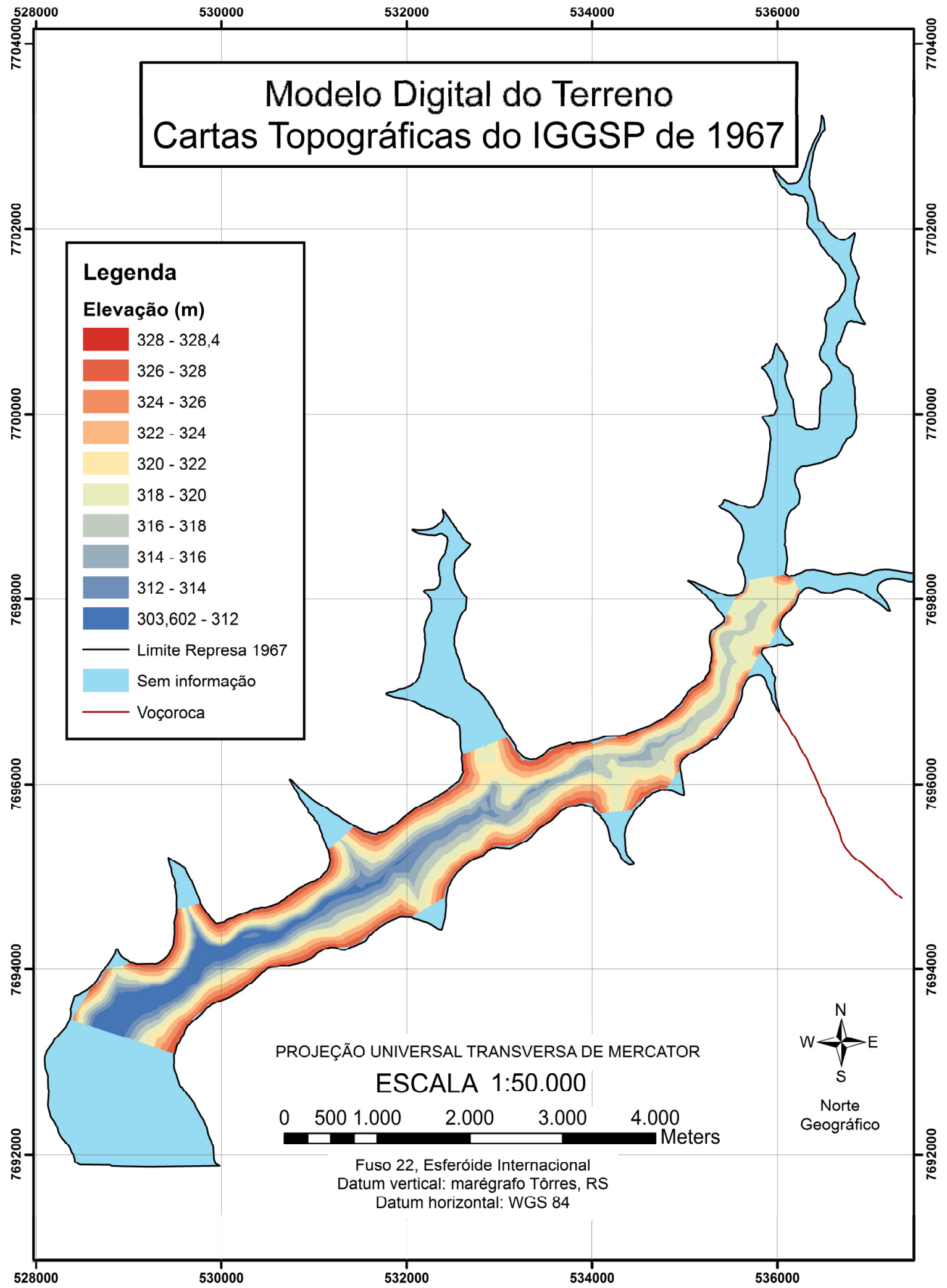




\section{APÊNDICE H -}

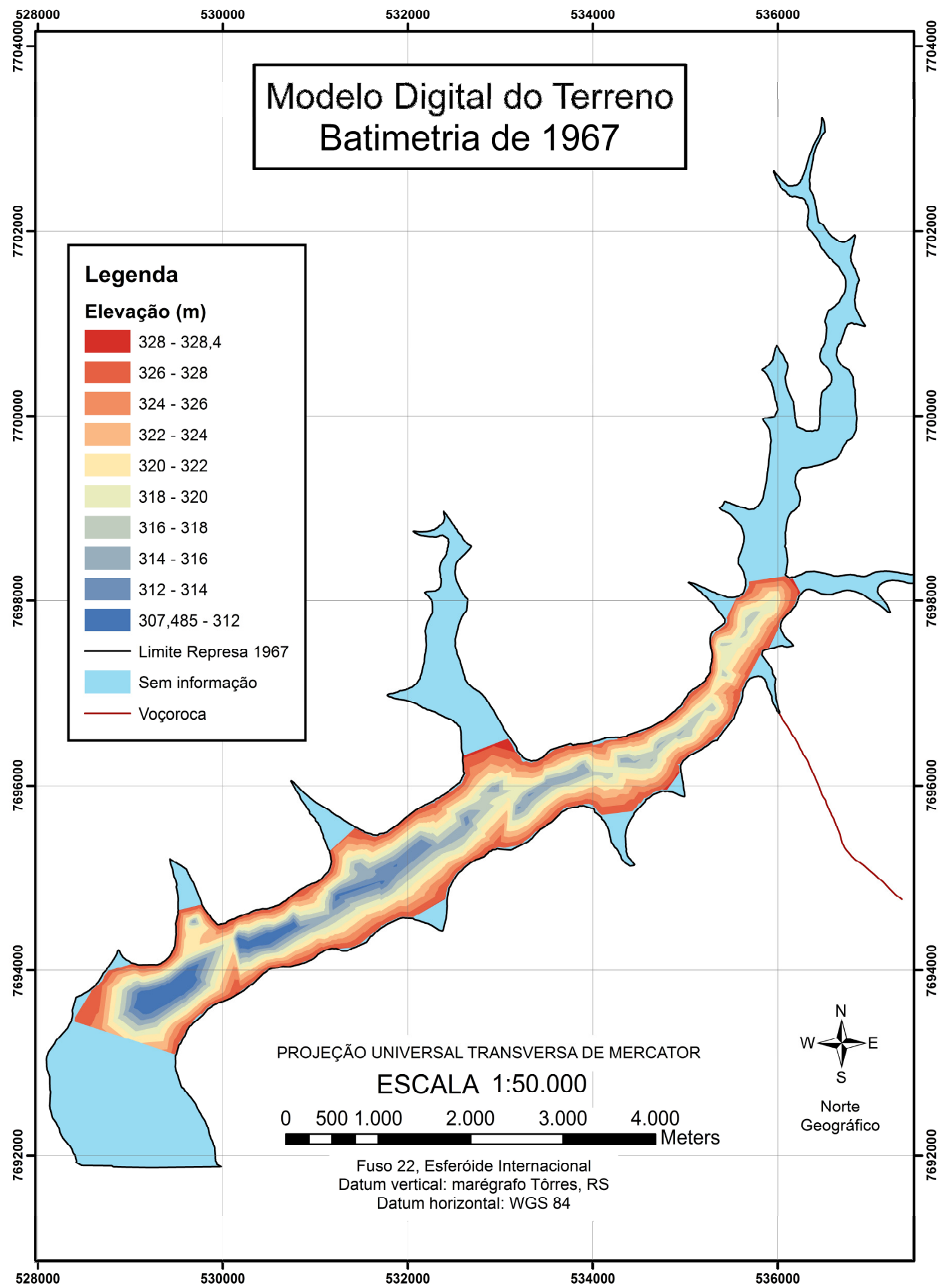


APÊNDICE I -

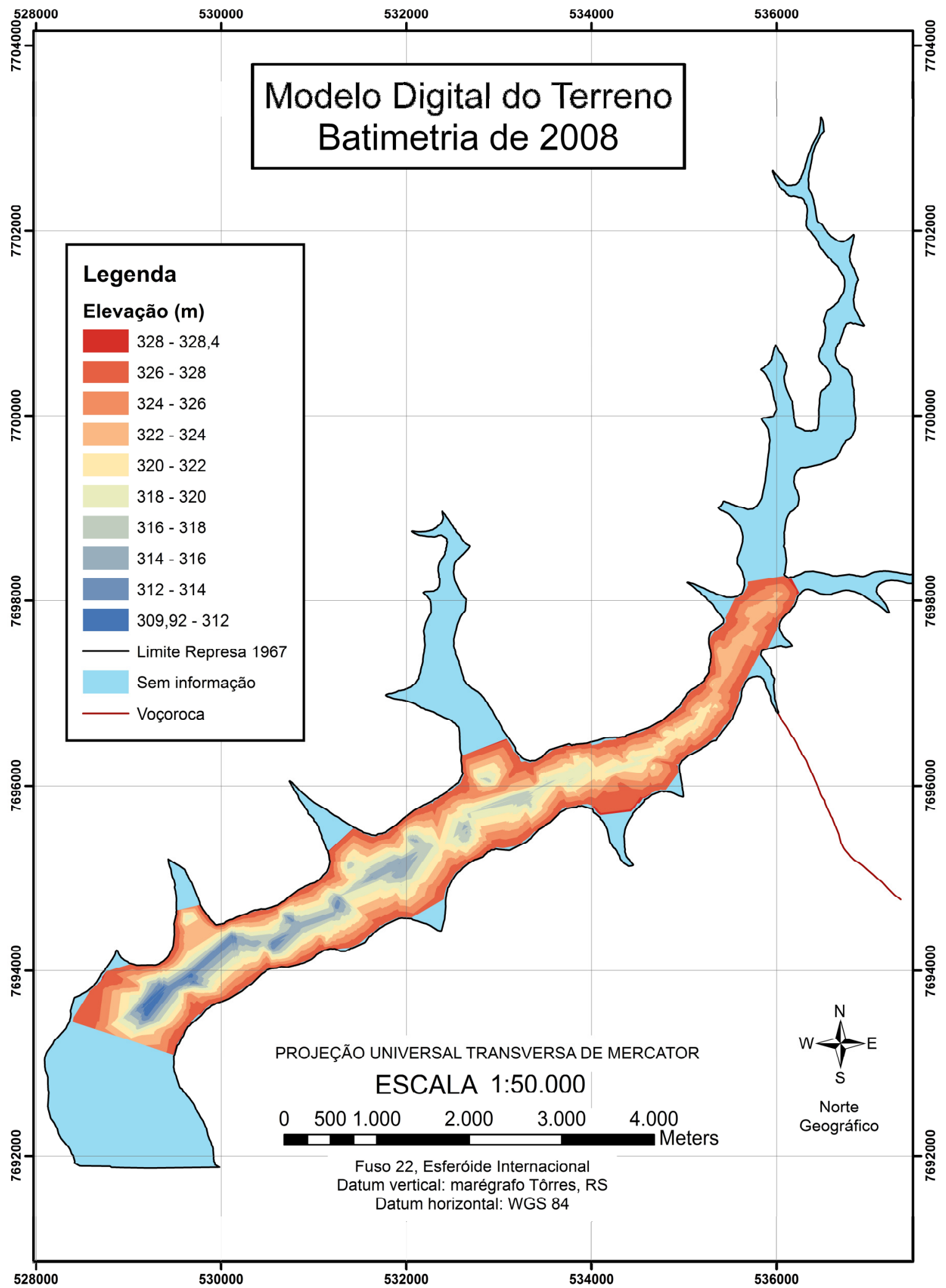


APÊNDICE J -

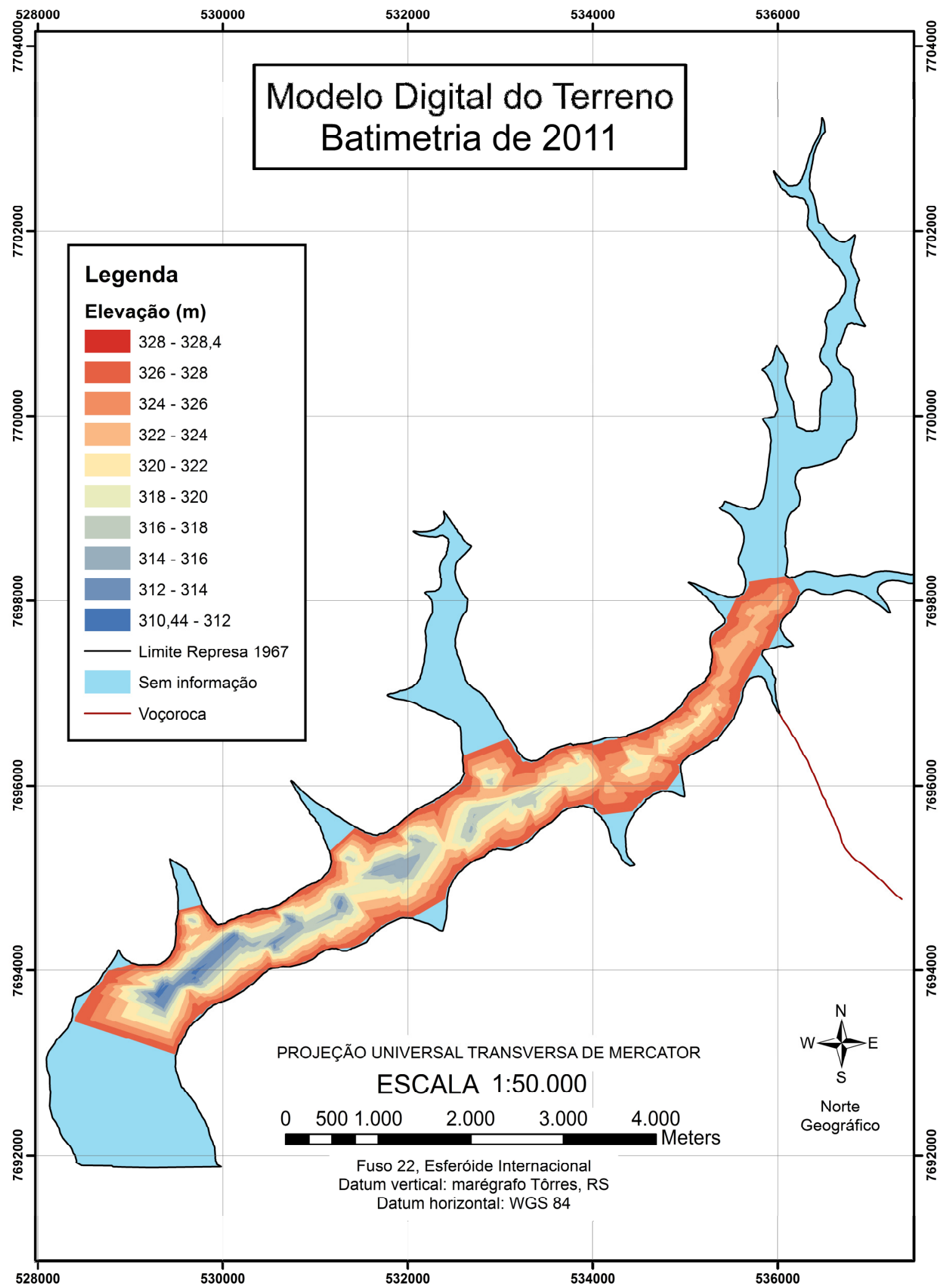


APÊNDICE K -

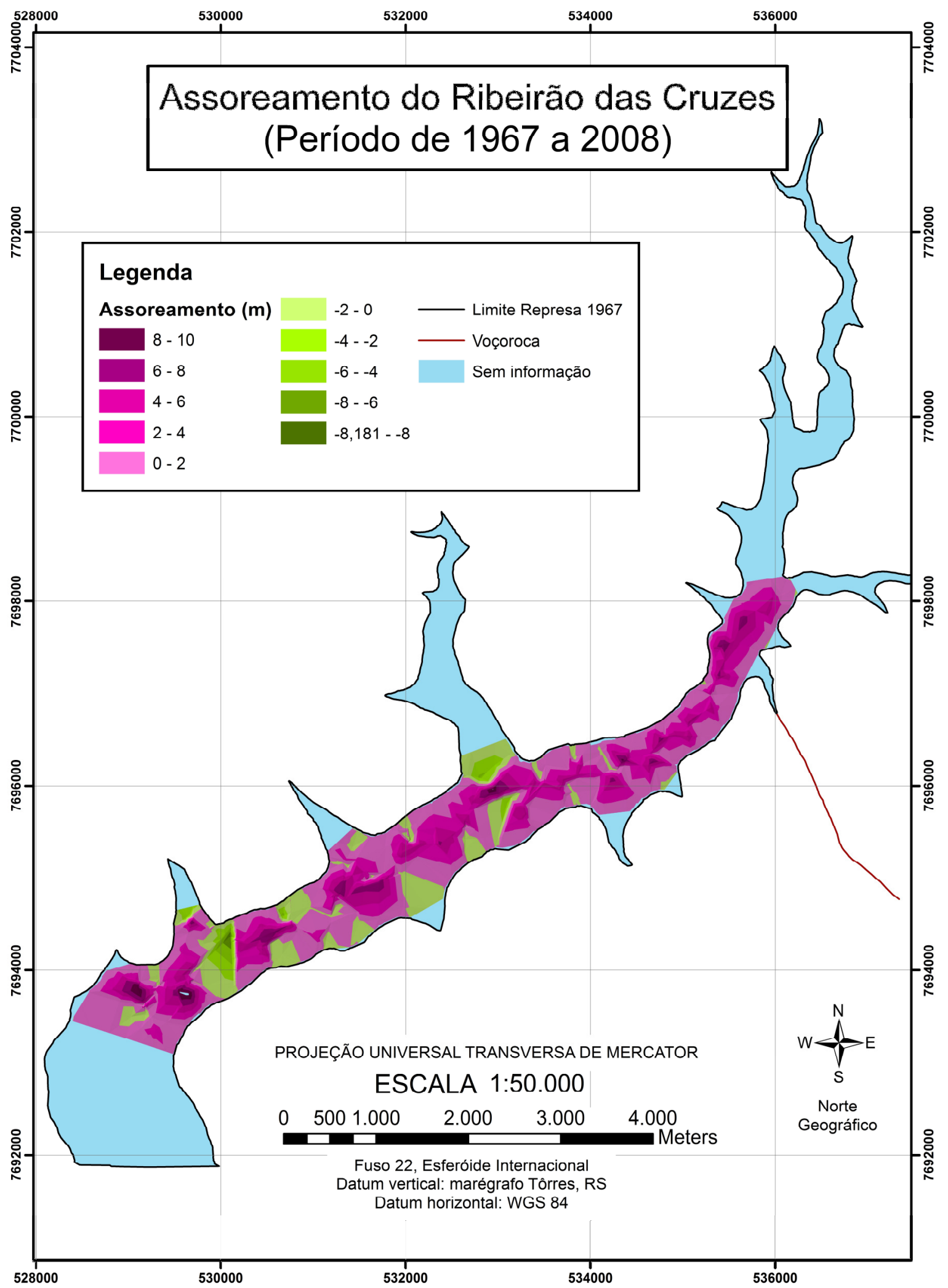


APÊNDICE L -

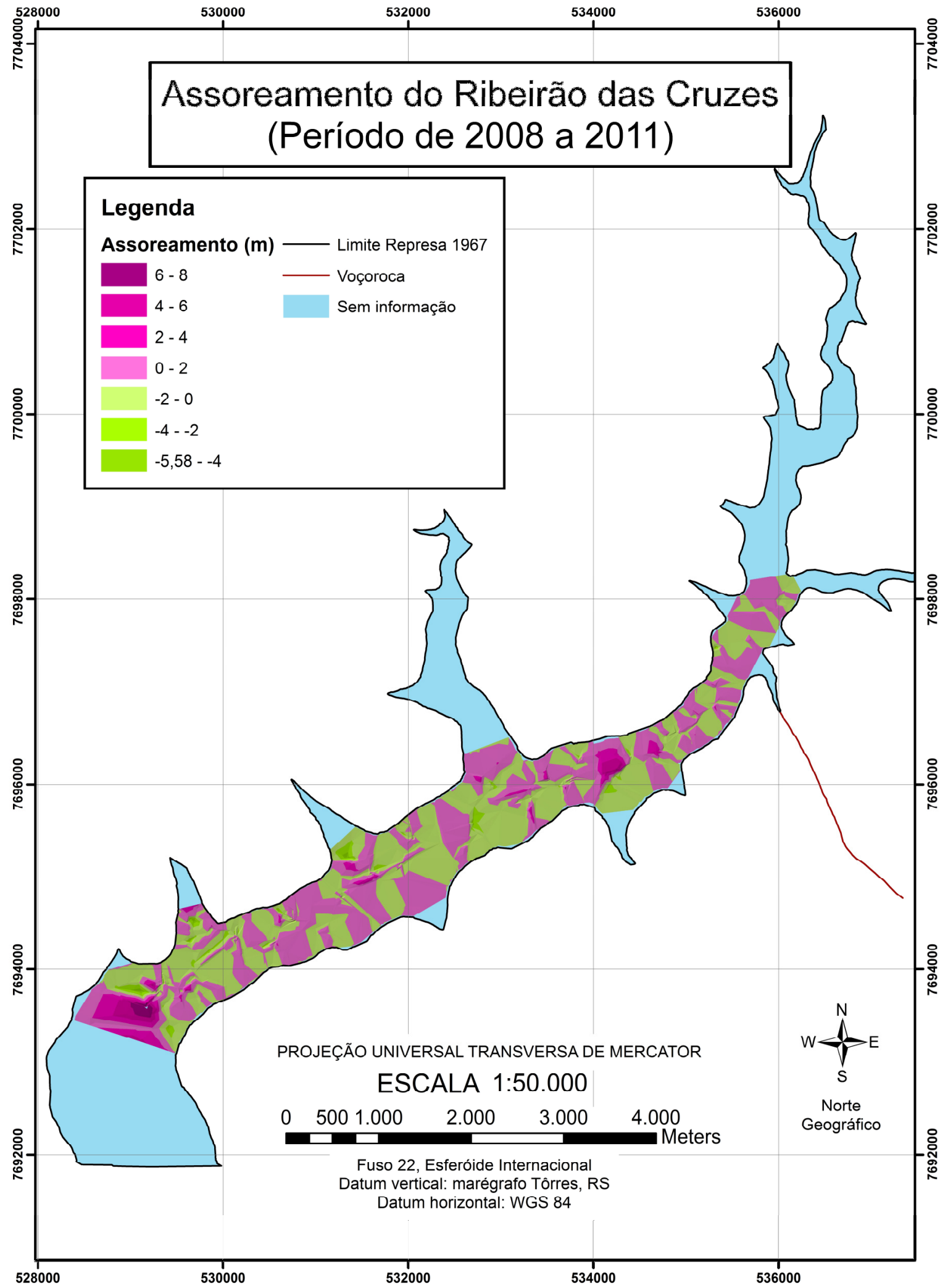


APÊNDICE M -

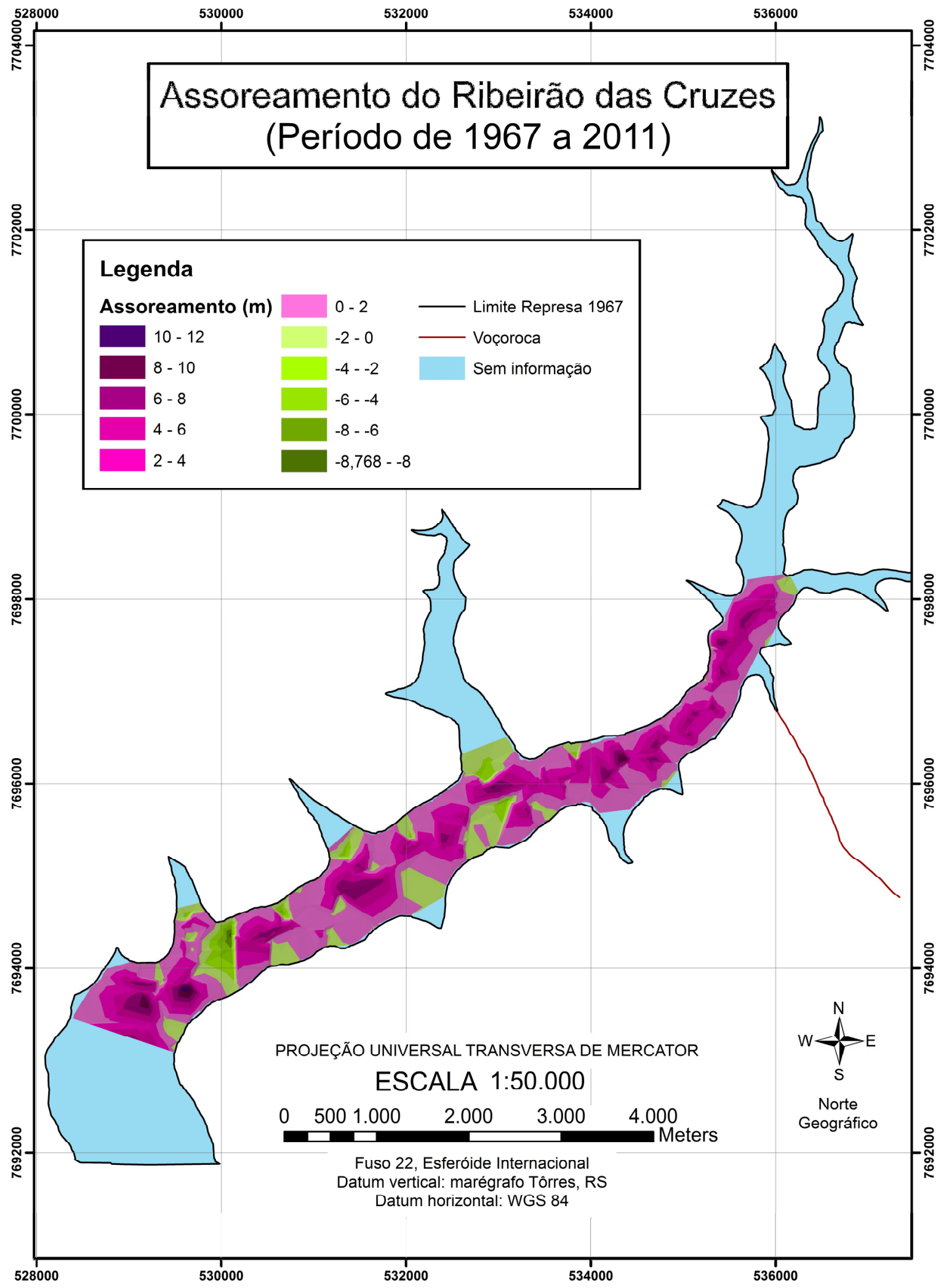

